\title{
Nuclear Power for Australia?
}

\section{Anthony Owen}

$\mathrm{I}$ n 2005 there were rising expectations for nuclear power. High rates of economic growth and energy demand, particularly from China and India, combined with environmental constraints, energy security concerns, and ongoing energy poverty in the developing world raised the possibility of a nuclear revival.

Worldwide there were 441 nuclear power plants operating at the end of 2005, totalling 368 GWe of generating capacity, and supplying about 16 per cent of the world's electricity. This latter figure has remained relatively stable over the past two decades, indicating that nuclear power has grown at about the same rate as total global electricity production over the period.

Current expansion, as well as perceived near-term and long-term growth prospects, is centred on Asia. Thomas (2005) reports that China, France, Korea and Japan have all announced possible orders over the next two years, although approval processes in France and Japan are likely to push back the scheduled dates of construction. Twenty four of the last 34 reactors to have been connected to the grid were in Asia.

At year-end 2005 there were 27 reactors described as being 'under construction' worldwide - although construction has effectively ceased on three of them, and for a further three construction started before 1990 and there must be doubts about whether these plants will ever be completed. Of those still under construction, 17 are based upon Indian, Russian, or Chinese technology, designs that would be highly unlikely to be adopted in OECD countries due to the rigours of the licensing processes required, and Western reactor manufacturers still face a dearth of new orders particularly from Europe and the United States.

Sixteen of the reactors under construction are in Asia and just one is in an Organisation for Economic Cooperation and Development (OECD) country (Finland). The Olkiluoto reactor in Finland is widely regarded as a special case. It is not being built for an electricity utility but rather for a consortium of industries who will guarantee to take all power on a 'not-for-profit' basis. It will not therefore compete in the Nordic electricity market. Construction costs are estimated to be $€ 3.2$ billion ( $€ 2000 / \mathrm{kW}$ ), with finance being provided by the Bayerische Landesbank (€1.95 billion) at a nominal interest rate of 2.6 per cent, and loan guarantees of $€ 720$ million from the French and Swedish export credit guarantee agencies. The European Commission is currently considering complaints that the plant has received illegal state subsidies. Whether or not these construction costs can be achieved (or repeated) is an unknown factor. The project is currently running nine months behind schedule.

Tony Owen is Associate Professor in the School of Economics at the University of New South Wales and a past President of the International Association for Energy Economics. 
In its 2006 Annual Energy Outlook, the US Energy Information Administration (EIA) projected increased US installed nuclear capacity from 99.6 GW in 2004 to $108.8 \mathrm{GW}$ in 2030. The increase comprised $6.0 \mathrm{GW}$ of capacity at new plants stimulated by the 2005 Energy Act (EPACT2005) tax incentives and 3.2 GW of capacity expansion at existing plants. EPACT2005 provides an 8-year production tax credit of $\$ 18$ per MWh for up to $6 \mathrm{GW}$ of capacity built before 2021, limited to $\$ 125$ million per 1000 -MW per year. If the capacity is reached before 2020, the credit program ends, and no additional units are expected. The increase in capacity at existing units assumes that all additions approved, pending, or expected by the Nuclear Regulatory Commission will be carried out. Other incentives offered to the nuclear industry in EPACT2005 were loan guarantees for up to 80 per cent of project cost - valid for all Greenhouse Gas (GHG)-free technologies insurance protection against delays during construction and until commercial operation caused by factors beyond the private sector's control; limitation of liability resulting from an accident; all decommissioning trust funds to qualify for tax deductibility; and the authorisation of a $\$ 2.95$ billion R\&D portfolio. Several companies have started the licensing process for new plants, but firm orders have yet to be made and even under a 'best case' scenario the first new plant would not come online until around 2015 at an existing site.

Even with this expansion of nuclear capacity, if it actually occurs, nuclear power's current 20 per cent share of total US generation is expected to decline to 15 per cent by 2030 . The EIA expects fifty per cent of all new generating capacity additions to 2030 to be coal in the absence of any carbon price being imposed on combustion of that fuel.

In summary, this is not a portrait of an industry in revival. Although the political will to expand nuclear capacity appears to be present in many OECD countries, as will be discussed below, electric utilities appear to be reluctant to support expansion.

The objective of this paper is to attempt to identify key parameters for determining the financial viability of nuclear power in Australia. This paper focuses on direct economic aspects of nuclear power, and largely ignores issues relating to public acceptability and nuclear waste disposal and plant decommissioning.

\section{Nuclear Power in Australia}

Currently, Australia has no commercially operating or planned nuclear power reactors and, as a nation well endowed with low-cost reserves of coal, this position would have been unlikely to change in the foreseeable future were it not for the threat of an impending global environmental crisis arising from the combustion of fossil fuels and a government commitment to a solution based upon a 'technology fix’ through its international Climate Action Partnerships.

However, this has not always been the case. Following the report of a feasibility study, in October 1969 the then Prime Minister (Gorton) announced that the Commonwealth government would construct a 500 MWe nuclear power 
station on Commonwealth land at Jervis Bay on the south coast of New South Wales. Tenders were obtained, and site preparation and environmental studies were undertaken by the Australian Atomic Energy Commission (AAEC). This was viewed as just the beginning of a substantial commitment by Australia to nuclear power. At the Australian and New Zealand Association for the Advancement of Science conference in May 1971, the Chairman of the AAEC, Sir Phillip Baxter, was quoted as stating that Australia's nuclear power capacity would reach 22.5 GWe by 1995, and 36 GWe by the year 2000, or 27.2 and 32.8 per cent respectively of projected total installed electricity capacity from all sources. (Both of these projections were way off beam. Installed electricity capacity from all sources was actually 37.7 GWe in 1995 and 46.6 GWe in the year 2000, whereas Baxter's projections implied capacity of 82.7 GWe and 110GWe respectively in those years.) Baxter's crystal ball was abruptly shattered just a few months later when the Jervis Bay project was deemed to be uneconomic and all construction plans deferred. Subsequently the project was abandoned and the prepared site now serves as a car park.

\section{The Challenge of Climate Change}

The ultimate objective of the 1992 United Nations Framework Convention on Climate Change (UNFCCC) was to stabilise greenhouse gas concentrations in the atmosphere at a level that would prevent dangerous human interference with the climate system. However, it soon became evident that in order to meet this objective it would be necessary to establish a legal instrument that would provide a sound basis for long-term co-operative global action. Negotiations concluded in Kyoto in December 1997 with the release of the Kyoto Protocol. The Kyoto Protocol established a legally binding obligation on Annex I Parties (which comprise all OECD nations, with the exceptions of Turkey, Mexico and Korea, and the 'transition' market economies of Eastern Europe; a total of 38 countries) to reduce emissions of GHGs by an average of 5.2 per cent below 1990 levels by the years 2008-2012. The Protocol became legally binding when the required 55 countries (including developing countries) accounting for at least 55 per cent of total 1990 carbon dioxide emissions had ratified it. This occurred on 16 February 2005, when the Russian Federation ratified. Australia and the USA are the only Annex I countries yet to ratify the Protocol.

The severe challenge posed by the requirement to reduce emissions of GHGs, especially in the electricity generation sector, has led to renewed worldwide interest in nuclear power for base-load electricity production, stimulated by its relatively low life-cycle GHG emissions footprint compared with fossil fuel technologies. A longer-term possibility is the production of 'carbon free' hydrogen for use with fuel cells in the transport sector, thus relieving the sector of its current heavy reliance on hydrocarbons. However, the question of whether nuclear power is a financially viable option remains an issue distorted by the raft of assumptions required to assess its generation costs. To the extent that such issues cause delays in construction of nuclear plant or restriction of operations, 
clearly they will also have a direct economic impact on the viability of nuclear technology.

\section{The Nuclear Fuel Cycle}

A nuclear power plant is simply a very large and expensive device for generating electricity using the heat generated by nuclear fission, a physical reaction. This differs from fossil fuel power plants which generate heat by combustion, a chemical reaction. Thereafter, the remaining steps in the process of electricity generation are very similar. The heat is used to produce steam, which drives turbines that turn electric generators.

The manufacture of fuel for nuclear power plants and its processing and management subsequent to reactor discharge are referred to as the 'front end' and 'back end' of the nuclear fuel cycle. In between lies the irradiation - the period when the fuel is contained within the core of the reactor.

The total fuel cycle comprises a number of activities, the possible combinations of which provide the various fuel cycle options. These activities are:

- $\quad$ uranium mining and milling;

- $\quad$ uranium refining and conversion to hexafluoride;

- uranium enrichment;

- fuel fabrication;

- reactor operation;

- $\quad$ spent fuel storage;

- $\quad$ spent fuel reprocessing;

- $\quad$ radioactive waste management; and

- decommissioning of nuclear facilities;

In addition, the fuel cycle also incorporates the transportation of various materials within the above activities.

The vast majority of nuclear power reactors in operation today operate on what is known as a 'once-through fuel cycle'. Strictly speaking this is not a cycle since the unused part of the spent fuel is not recycled. The spent fuel is not reprocessed but is kept in temporary storage until it can be sent for permanent disposal by, for example, conditioning it and placing it underground in a deep geological repository.

\section{Life Cycle Analysis of the Nuclear Fuel Cycle}

When comparing the environmental footprints of alternative energy technologies, it is important that the power generation or combustion stage of the technology not be isolated from other stages of the 'cycle'. For example, a nuclear power reactor does not emit GHGs in its operation. However production of its 'fuel' (that involves the first four dot points above) may involve significant quantities of GHG 
emissions. To avoid such distortions, the concept of life cycle analysis (LCA) has been developed.

LCA is based upon a comprehensive accounting of all energy and material flows, from 'cradle to grave', associated with a system or process. The approach has typically been used to compare the environmental impacts associated with different products that perform similar functions, such as plastic and glass bottles. In the context of an energy product, process, or service, a LCA would analyse the site-specific environmental impact of fuel extraction, transportation and preparation of fuels and other inputs, plant construction, plant operation, waste disposal, and plant decommissioning. Thus it encompasses all segments including upstream and downstream processes and consequently permits an overall comparison (in a cost benefit analysis framework) of short- and long-term environmental implications of alternative energy technologies. Central to this assessment is the valuation of environmental externalities of current and prospective fuel and energy technology cycles. It should be noted, however, that only material and energy flows are assessed in an LCA, thus ignoring some crucial elements such as supply security and technology reliability and flexibility.

\section{The Methodology}

Life-cycle analysis involves the following methodological steps:

- Definition of the product cycle's geographical, temporal, and technical boundaries;

- Identification of the environmental emissions and their resulting physical impacts on receptor areas; and

- Quantifying these physical impacts in terms of monetary values.

These steps describe a 'bottom up', as distinct from a 'top down', methodology for life cycle analysis. Top-down studies use highly aggregated data to estimate the environmental costs of pollution. They are typically undertaken at the national or regional level using estimates of total quantities of emissions and estimates of resulting total damage. The proportion of such damage attributable to certain activities (for example, the transport sector) is then determined, and a resulting monetary cost derived. The exercise is generic in character, and does not take into account impacts that are site specific. However, its data requirements are relatively minor compared with the 'bottom up' approach. The latter involves analysis of the impact of emissions from a single source along an impact pathway. Thus all technology data are project specific. When this is combined with emission dispersion models, receptor point data, and dose-response functions, monetised values of the impacts of specific environmental externalities can be derived. Data requirements are relatively large compared with the 'top down' methodology, and therefore omissions may be significant.

Traditionally, LCA has omitted the third of the above steps and the final analysis has therefore been expressed in terms of just the biophysical impacts that 
can be quantified. The extension to include costing of these impacts is generally known as the 'impact pathway' methodology. Essentially, however, it can be considered as a specific application of LCA. This methodology formed the theoretical basis for the European Commission's ExternE study, which was the first comprehensive attempt to use a consistent 'bottom-up' methodology to evaluate the environmental damages associated with a range of different fuel cycles. The European Commission (EC) launched the project in collaboration with the US Department of Energy in 1991. The EC and US teams jointly developed the conceptual approach and the methodology and shared scientific information for its application to a range of fuel cycles. The main objectives were to apply the methodology to a wide range of different fossil, nuclear and renewable fuel cycles for power generation and energy conservation options. Although the US withdrew from the project, a series of National Implementation Programmes to realise the methodology for reference sites throughout Europe was completed. The methodology was subsequently extended to address the evaluation of externalities associated with the use of energy in the transport and domestic sectors.

Table 1: Environmental Damage Costs from Electricity Production in the European Union

\begin{tabular}{|c|c|c|c|c|c|c|c|c|c|}
\hline \multicolumn{10}{|c|}{ (range: €థ/kWh) } \\
\hline Country & $\begin{array}{l}\text { Coal \& } \\
\text { Lignite }\end{array}$ & Peat & Oil & Gas & Nuclear & Biomass & Hydro & $\begin{array}{c}\text { Photo- } \\
\text { voltaics }\end{array}$ & Wind \\
\hline Austria & & & & $1-3$ & & $2-3$ & 0.1 & & \\
\hline Belgium & $4-15$ & & & $1-2$ & 0.5 & & & & \\
\hline Germany & $3-6$ & & $5-8$ & $1-2$ & 0.2 & 3 & & 0.6 & 0.05 \\
\hline Denmark & $4-7$ & & & $2-3$ & & 1 & & & 0.1 \\
\hline Spain & $5-8$ & & & $1-2$ & & $3-5$ & & & 0.2 \\
\hline Finland & $2-4$ & $2-5$ & & & & 1 & & & \\
\hline France & $7-10$ & & $8-11$ & $2-4$ & 0.3 & 1 & 1 & & \\
\hline Greece & $5-8$ & & 3-5 & 1 & & $0-0.8$ & 1 & & 0.25 \\
\hline Ireland & $6-8$ & $3-4$ & & & & & & & \\
\hline Italy & & & $3-6$ & $2-3$ & & & 0.3 & & \\
\hline Netherlands & $3-4$ & & & $1-2$ & 0.7 & 0.5 & & & \\
\hline Norway & & & & $1-2$ & & 0.2 & 0.2 & & $0-0.25$ \\
\hline Portugal & $4-7$ & & & $1-2$ & & $1-2$ & 0.03 & & \\
\hline Sweden & $2-4$ & & & & & 0.3 & $0-0.7$ & & \\
\hline $\begin{array}{l}\text { United } \\
\text { Kingdom }\end{array}$ & $4-7$ & & $3-5$ & $1-2$ & 0.25 & 1 & & & 0.15 \\
\hline
\end{tabular}

Source: European Commission (2003)

Table 1 summarises the results of the EC study for electricity production. The data are based upon specific plants in the countries concerned and combine damages from both local and global pollutants. In the case of the former, therefore, damages are highly dependent upon the population density of the receptor area, and do not reflect industry-wide costs. Nevertheless they give an indicative range for each technology when taken over all countries. From this 
table, nuclear power's appeal as a low-pollution electricity generation option is very evident.

Conversely, environmental damage arising from the combustion of coal in power plants clearly gives cause for concern and consequently the move to gas as an alternative, if more expensive, fuel would be easy to justify for a utility.

\section{The Economics of Environmental Externalities}

Externalities are defined as benefits or costs generated as an unintended byproduct of an economic activity that do not accrue to the parties involved in the activity and where no compensation takes place. Environmental externalities are benefits or costs that manifest themselves through changes in the physicalbiological environment.

Pollution emitted by road vehicles and by fossil fuel fired power plants during power generation is known to result in harm to both people and the environment. In addition upstream and downstream externalities, associated with securing fuel and waste disposal respectively, are generally not included in power or fuel costs. To the extent that the ultimate consumers of these products do not pay these environmental costs, nor compensate others for harm done, they do not face the full cost of the services they purchase (that is, implicitly their energy use is being subsidised) and thus energy resources will not be allocated efficiently.

It's almost a century since Arthur Pigou published his Wealth and Welfare (1912), which brought social welfare into the scope of economic analysis. In particular, Pigou is responsible for the distinction between private and social marginal products and costs and the idea that governments can, via a mixture of taxes and subsidies, correct such market failures - or 'internalize the externalities'. At the time these ideas were regarded as an academic curiosity, but a couple of generations later were reincarnated as the Polluter-Pays-Principle (PPP).

Historically, in Australia in common with all OECD countries, the external (largely environmental) damage resulting from the combustion of fossil fuels by power plants have not been 'internalised' in the price of electricity to the ultimate consumer. Thus, effectively, electricity consumption has been subsidised and as a consequence demand (and hence environmental degradation) has been higher than it would have been if pollution control costs had been imposed on the consumer. Recently, in response to their obligations under the Kyoto Protocol, European Union nations have introduced a carbon dioxide $\left(\mathrm{CO}_{2}\right)$ emissions trading scheme that is designed to internalise the cost of controlling $\mathrm{CO}_{2}$ emissions, but it is suffering from a number of practical problems which make the alternative, the politically impossible 'carbon tax', a more appealing option from a practical standpoint. Although these two instruments are equivalent in theory, in practice they can differ significantly if, as would seem likely, the marginal abatement costs of the polluting entities are not known precisely (this divergence is illustrated in Perman et al, 2003:254-256). 


\section{The Cost of Nuclear Power}

Nuclear power plants have a 'front-loaded' cost structure; that is, they are relatively expensive to build but relatively inexpensive to operate. Although costs vary both between and within countries, about two-thirds of the costs of generating electricity from a nuclear power plant are accounted for by fixed costs, with the remainder being operating costs, could be taken as indicative figures. The main fixed costs are capital repayments and interest on loans, but the decommissioning cost is also included in this item. Fuel is a relatively minor component of operating costs, because uranium is in relatively abundant supply in terms of current requirements. Investment cost per $\mathrm{kWe}$ at the design stage for nuclear plant is about two and a half times that for coal and three times that for combined cycle gas turbine plants. However, the costs of large scale engineering projects are notoriously difficult to project, being very site specific, and construction cost blow outs are very common in practice. This problem would have a far greater cost impact on nuclear, given that much of the investment for the other two technologies is fabricated in factories and sold under turnkey arrangements.

Once a nuclear power plant has been built, its construction costs have effectively been 'sunk' and the plant's second-hand value is negligible. Thus it makes financial sense to operate the plant continuously based upon the fact that low fuel costs effectively yield a relatively low marginal cost for power production. Thus, currently, nuclear power is the cheapest form of electricity production in most OECD countries with existing plants and utilities are attempting to extend the life of current plants to capitalise on this advantage. However, they appear very reluctant to invest in new nuclear plant without substantial government cost and market guarantees and other subsidies.

For new nuclear power plants, their competitiveness depends on several factors. First, the cost of alternative technologies. Nuclear is likely to be particularly suitable for countries that are not well endowed with coal or oil reserves and must therefore import their fossil fuels. Second, it depends on the overall electricity demand in a country and its rate of growth. Third, it depends on the market structure and investment environment. In general, nuclear power's front loaded cost structure is less attractive to a private investor in a liberalised market that values short-term returns than to a government-owned utility that has a longer-term perspective. Private investments in liberalised markets will also depend on the extent to which energy-related environmental externalities (for example, GHG emissions, emissions of local pollutants, etc.) and the value of energy security have been 'internalised'. In contrast, government investors can incorporate such externalities directly into their decisions, although this implicitly contravenes the PPP. Different countries have different approval processes, regulatory regimes and political systems, all of which impact on risk from an investors viewpoint. Construction delays, for example, can significantly increase interest payments during construction. 
Thomas (2006) reports that 'Forecasts of construction costs have been notoriously inaccurate, frequently being a serious underestimate of actual costs and - counter to experience with most technologies where so-called 'learning', scale economies, and technical progress have resulted in reductions in the real cost of successive generations of technology - real construction costs have not fallen and have tended to increase through time.' This lack of scale economies is not surprising given the lack of orders for new generation (often called 'Advanced') reactors. The so-called Generation III and Generation III+ designs are likely to be the preferred technology choice for OECD countries. They differ from previous designs in that they incorporate a greater level of passive, as opposed to engineered, safety. They also benefit from standardisation and simplification of design, factors that should offer economies of scale in production, licensing, and operation.

Joskow (2006) has compared the pre-construction overnight cost (that is, the amount that would be paid out, net of interest charges, if all capital expenses occurred simultaneously) estimates for 75 nuclear power plants built in the US with their actual cost, adjusted to remove the impacts of inflation (Table 2). He notes that nobody has ever underestimated the construction cost of a nuclear power plant at the pre-construction stage!

Table 2: Historical US Construction Cost Experience 75 pre-Three Mile Island plants operating in 1986: \$2002/kWe

\begin{tabular}{l|ccc}
\hline $\begin{array}{l}\text { Construction } \\
\text { started }\end{array}$ & $\begin{array}{c}\text { Estimated overnight } \\
\text { Cost }\end{array}$ & $\begin{array}{c}\text { Actual overnight } \\
\text { cost }\end{array}$ & Actual/Estimated \\
\hline $1966-67$ & $\$ 560 / \mathrm{kWe}$ & $\$ 1170 / \mathrm{kWe}$ & $209 \%$ \\
$1968-69$ & $\$ 679 / \mathrm{kWe}$ & $\$ 2000 / \mathrm{kWe}$ & $294 \%$ \\
$1970-71$ & $\$ 760 / \mathrm{kWe}$ & $\$ 2650 / \mathrm{kWe}$ & $348 \%$ \\
$1972-73$ & $\$ 1117 / \mathrm{kWe}$ & $\$ 3555 / \mathrm{kWe}$ & $318 \%$ \\
$1974-75$ & $\$ 1156 / \mathrm{kWe}$ & $\$ 4410 / \mathrm{kWe}$ & $381 \%$ \\
$1976-77$ & $\$ 1493 / \mathrm{kWe}$ & $\$ 4008 / \mathrm{kWe}$ & $269 \%$ \\
\hline
\end{tabular}

Based upon this experience, it is not surprising that Thomas Capps, at the time CEO of Dominion Resources Inc. that currently operates four nuclear plants, in response to new US government incentives ${ }^{1}$ (that is, subsidies) to promote a new generation of nuclear power plants, stated:

President Bush may be cheerleading for nuclear power, but the electric industry is not ready to order new reactors. We aren't going to build a nuclear plant anytime soon. Standard \& Poor's and Moody's would have

\footnotetext{
${ }^{1}$ The Nuclear Power 2010 program, launched in 2002, is a concerted effort by the Bush Administration to encourage a revival of ordering of nuclear plant based upon the next generation (known as Generation III+) of plant designs. Essentially it supports cooperative projects between the US Department of Energy and the power industry.
} 
a heart attack. And my chief financial officer would, too. (New York Times, May 2, 2005)

Capps argued that the proposed incentives did not go far enough.

A new 1400-megawatt nuclear power plant is going to cost about \$2.6 billion ... . It is going to take $6 \frac{1}{2}$ years to build. While you are building, you have to issue equity. You have to issue bonds; you have to service the bonds with interest. You don't have any money coming in. You have an average of $\$ 1.3$ billion out for $6 \frac{1}{2}$ years that is not earning anything. ... We are not going to build one under those financial conditions. (Washington Post July 24, 2005)

Capps' main concern was that anti-nuclear protestors would obstruct the operating approval process of new plants through court challenges and that such delays would cause unacceptable financial risks.

The cost of capital (that is, the interest rate) is, together with construction costs, a major determinant of the cost of power from a nuclear plant. Most nuclear plants currently operating in OECD countries were built in an era when the power generation sector was a regulated monopoly. Thus the cost of capital was low, as it was backed by government guarantee. In addition, any increase could be clawed back from consumers in the form of higher prices arising from the full cost recovery nature of the sector pricing regime. Thus investment risk, which effectively was vested in the consumer/tax payer, was minimal and hence the cost of capital reflected this.

However, OECD electricity markets (including that of Australia) have undergone reconstruction, to various degrees, to a model that is driven by competitive forces, and thus the investment risk now falls on the generator rather than consumer. In such circumstances the real cost of capital could be expected to be considerably higher than under the former regime. Of course, this risk could be reduced by government guarantees but this amounts to a subsidy and is therefore in conflict with the competitive market model.

Financial estimates of the cost of electricity generation from new nuclear power plants are subject to large variations, both between and within countries (as can be seen by the construction cost data given in Table 3). Thomas lists a number of reasons for the divergence:

- It is always assumed that new plants would be much cheaper and more reliable than existing plants.

- Those with a vested interest in nuclear power would tend to produce the more optimistic costs and performance forecasts.

- Few orders have been placed in the past two decades on which to base forecasts.

- Very little real data on construction and operating costs are made public.

- All designs currently being considered in the USA and the EU are unproven. 
- There is a variety of assumptions regarding the cost of capital (which are very evident from Table 3). Real rates of 10 per cent, or above, severely compromise the viability of nuclear power yet rates lower than this are difficult to justify for private investors.

Table 3: Forecasts of Generating Costs for New Nuclear Plant

\begin{tabular}{|c|c|c|c|c|c|c|}
\hline Forecast & $\begin{array}{c}\text { Construction } \\
\text { Cost } \\
(€ / \mathbf{k W})\end{array}$ & $\begin{array}{c}\text { Cost of } \\
\text { capital } \\
\text { (\% real) }\end{array}$ & $\begin{array}{c}\text { Load } \\
\text { Factor } \\
(\%)\end{array}$ & $\begin{array}{c}\text { Operating } \\
\text { Life } \\
\text { (years) }\end{array}$ & $\begin{array}{c}\text { Generating } \\
\text { Cost } \\
(€ \notin / \mathbf{k W h})\end{array}$ & $\begin{array}{c}\text { Generating } \\
\text { Cost } \\
(\mathrm{A} \Phi / \mathbf{k W h})\end{array}$ \\
\hline $\begin{array}{l}\text { Canadian } \\
\text { Nuclear Ass }\end{array}$ & 1557 & 10 & 90 & 30 & 4.82 & 8.03 \\
\hline Chicago & 810 & & & & 4.23 & 7.05 \\
\hline University & $\begin{array}{l}1216 \\
1460\end{array}$ & 12.5 & 85 & 40 & $\begin{array}{l}4.96 \\
5.69\end{array}$ & $\begin{array}{l}8.27 \\
9.48\end{array}$ \\
\hline IEA/NEA & $1606-3650$ & $\begin{array}{c}5 \\
10\end{array}$ & 85 & 40 & $\begin{array}{c}1.75-3.94 \\
2.6-5.5\end{array}$ & $\begin{array}{l}2.92-6.57 \\
4.33-9.17\end{array}$ \\
\hline $\begin{array}{l}\text { Lappeenranta } \\
\text { University }\end{array}$ & 1748 & 5 & 91 & 40 & 2.23 & 3.72 \\
\hline OXERA & $\begin{array}{c}2372 \\
\text { (first unit) } \\
1679 \\
\text { (later unit) }\end{array}$ & & 95 & 40 & & \\
\hline MIT & 1622 & 11.5 & $\begin{array}{l}85 \\
75\end{array}$ & $\begin{array}{l}40 \\
25\end{array}$ & $\begin{array}{l}5.4 \\
6.4\end{array}$ & $\begin{array}{c}9.00 \\
10.67\end{array}$ \\
\hline Performance & & 8 & $>80$ & 30 & 3.37 & 5.62 \\
\hline $\begin{array}{l}\text { \& Innovation } \\
\text { Unit }\end{array}$ & $<1226$ & $\begin{array}{c}8 \\
15\end{array}$ & & $\begin{array}{l}15 \\
15\end{array}$ & $\begin{array}{l}4.13 \\
5.53\end{array}$ & $\begin{array}{l}6.88 \\
9.22\end{array}$ \\
\hline RAE & 1679 & 7.5 & 90 & 40 & 3.36 & 5.60 \\
\hline UBS & 2044 & - & 91 & 45 & 3.06 & 5.10 \\
\hline EPR & 2031 & 8 & 90.3 & 60 & 3.00 & 5.00 \\
\hline Sizewell B & 5110 & - & 84 & 40 & - & \\
\hline Gittus & 1708 & 5 & 90 & 40 & 2.18 & 3.63 \\
\hline
\end{tabular}

Source: Adapted from Thomas (2005)

\section{Energy Subsidies}

Support that lowers the cost of power generation can take many forms, including support to the use of inputs (for example, water, fuels, etc.), public financing at interest rates below the market value, tax relief on corporate income, lump sum support to fixed capital investment in research and development, etc. Examples include the exemption of government-owned electricity generators from corporate income tax payments (increasing the relative after tax rate of return compared with electricity generation by private enterprises) or the provision of loans at interest 
rates below market rates, or over repayment periods in excess of market terms (which favour capital intensive energy forms).

Energy subsidies are particularly prevalent in developing countries, where energy prices typically contain a 'social' subsidy to enable the poor to receive basic lighting services. Perhaps the most extreme case of energy subsidies in the developed world involves the nuclear power industry, where various OECD governments subsidise the industry's fuel supply services, waste disposal, fuel processing, and research and development. In addition, they also limit the liability of plants in case of accident, and help them clean up afterwards.

\section{Civil Liability and Insurance}

Civil liability for nuclear damage is limited by both national legislation and international conventions. In the case of the latter, a 1997 amendment to the IAEA Vienna Convention limits operator liability to 300 million SDRs (about $€ 360$ million). It entered into force in 2003, but with few members. In 2004 contracting parties to the OECD Paris and Brussels Conventions set liability levels at $€ 1500$ million, but these have yet to be ratified. Thereafter, there appears to be a tacit acceptance that the relevant state will make funds available to cover any excess.

In the USA the Price-Anderson Act, the world's first comprehensive nuclear liability law, has since 1957 limited the liability of US nuclear electrical generating facilities in the event of an accident. Under the terms of its 20 year renewal in 2005, individual operators are responsible for two layers of insurance cover. Private cover of $\$ 300$ million per nuclear site from private insurers, combined with a joint fund of $\$ 96$ million per reactor (adjusted for inflation) paid retrospectively in instalments (if required). The total provision amounts to \$10 billion. Above this figure, the US Congress acts as insurer of last resort.

Whether these liability limits constitute a subsidy designed to encourage the installation of nuclear power facilities or simply government responsibility for providing last resort assistance for victims of major disasters, natural or otherwise, is a contentious issue. Without them it is unlikely that the US or EU nuclear power industries could purchase full indemnity in the commercial insurance marketplace.

\section{Internalising Environmental Externalities}

Table 1 illustrated the environmental benefits offered by nuclear power, as opposed to its fossil fuel (and particularly coal) counterparts. However, these were damage costs, whereas the appropriate pricing of carbon would be based upon control costs. Damage costs are a measure of society's loss of wellbeing resulting from the damage arising from a specific adverse environmental impact, and are appropriately included in cost-benefit analyses. Control costs are what it costs society to achieve a given standard that restricts the extent of the impact to an acceptable level and this is what is required for meeting Kyoto Protocol-style obligations. Essentially, unit control costs can be calculated simply by dividing 
the cost of mandated controls by the emissions reduction achieved by the controls. The implicit assumption in control costing is that society controls pollution until the benefit of additional controls would be outweighed by the cost of their imposition.

Where environmental externalities are 'internalised' (even, if only partially) then they can legitimately be included in the financial analysis as they represent a true cost to the investor. The European Emissions Trading Scheme (ETS) was established in 2005 to reduce EU $\mathrm{CO}_{2}$ emissions in accordance with its obligations under the Kyoto Protocol. In theory, setting a pollution emissions 'cap', allocating permits to pollute to this cap, and facilitating permit trading amongst polluters should ensure a least-cost reduction of total pollutants to (at most) the level of the cap. To the extent that electricity generators using fossil fuel plants and other significant emitters of $\mathrm{CO}_{2}$ exceed their quota, they will be obliged to purchase permits and pass the cost on to their customers. Thus a 'price' for carbon is established (that is, the environmental externality is, at least partially, internalised) and the cost of electricity from fossil fuel plants would rise correspondingly. At least that's the theory.

In practice, the scheme's first year of operations has been dysfunctional. Lax allocation of allowances by most member states resulted in the distribution of permits to the value of 1829 million tonnes $\mathrm{CO}_{2}$ in 2005. Actual emissions were only 1785 million tonnes. So, in aggregate, the market was experiencing oversupply of permits and the scheme was simply not reducing emissions of $\mathrm{CO}_{2}$. In fact, only four of the 25 member states had targets which were lower than their actual emissions! The exceptions at the sector level were power stations which were set, in general, very tight targets. Thus the scheme has really only acted as a tax on power stations with a resulting increase in electricity prices (which could probably have been accomplished far more efficiently with a simple energy tax).

In late August 2006, permits were trading for around €16-17/tonne $\mathrm{CO}_{2}$ (A $\$ 27-29 / \mathrm{tCO}_{2}$ ), equivalent to about 1.5 euro cents/kWh for coal-fired generation, having declined significantly when the market was informed of the over-allocation noted above. At this price level, the disincentive for using coal is very low. But it is an actual cost that must be paid by generators and thus indirectly financially encourages non-fossil sources of electricity supply.

More generally, the cost of controlling global $\mathrm{CO}_{2}$ emissions to a universally agreed specified level should be the actual control cost imposed on emitters, not that of a highly contrived and limited market such as the EU ETS. It is difficult to give even a ballpark figure as to what this cost could be, since estimates of the marginal cost of GHG emissions damage cover a vast range. Toll (2005) has concluded that, based upon a survey of 103 estimates, 'one can therefore safely say that, for all practical purposes, climate change impacts may be very uncertain but is unlikely that the marginal damage costs of carbon dioxide emissions exceed $\$ 50 / \mathrm{tC}$ (or approximately $\mathrm{A} \$ 68 / \mathrm{tC}$ or $\mathrm{A} \$ 18.50 / \mathrm{CO}_{2}$ ) and are likely to be substantially smaller than that'. Since, logically, control costs must be less than damage costs this would represent an upper bound. However, the cost would be far too uncertain to have confidence that a (politically unpopular) carbon tax, 
imposed universally, would achieve the desired objective of reducing $\mathrm{CO}_{2}$ emissions from the power sector to an acceptable level.

\section{The Debate in Australia}

In Australia, the Australian Nuclear Science and Technology Organisation (ANSTO) fuelled the debate by commissioning a study entitled Introducing Nuclear Power to Australia: an Economic Comparison from John Gittus, a UKbased consultant. ${ }^{2}$ The report concluded that, with appropriate subsidies, a 'new' generation of nuclear power plants could produce electricity in Australia at a cost that was competitive with coal. Gittus then built in to his analysis the cost of damage arising from emissions of $\mathrm{CO}_{2}$ and local pollutants from fossil fuel plants, thus giving nuclear power a pronounced 'economic' advantage. Economists would, of course, recognise this transition from a financial analysis to a cost benefit analysis, but would question its partial nature. What Gittus has produced is a 'mongrel' analysis. A correct formulation of an economic analysis would also net out of the calculations all subsidies and taxes, and shadow price other factors of production where appropriate. This would give a very different picture of the true resource use associated with a nuclear plant (i.e. a proper cost benefit analysis). As noted earlier, however, it is the cost of controlling $\mathrm{CO}_{2}$ emissions that is the relevant add-on environmental cost for power stations operating in the private sector, and at present this cost is negligible in Australia.

Without imposing a cost on carbon, the Australian government is effectively subsidising domestic carbon emitting industries. To 'correct' this imbalance its answer appears to be the provision of subsidies for 'negligible' carbon emitting technologies (such as nuclear and renewables). However, as has already been noted, subsidies not only result in higher demand and consequently greater pollution than in a non-subsidised regime, they also result in a net loss of welfare to society.

There is currently a proposal before the state governments to introduce a capand-trade carbon permit trading mechanism for power utilities in Australia, under the auspices of the National Emissions Trading Taskforce. If properly designed and with an affective 'cap', this should impose control costs on power stations that will ultimately be passed on to the consumer of electricity in the form of higher prices. Incentives to modify carbon emitting activities then arise for both producers and consumers of electricity. Since the permits will have value, producers will have an incentive to adopt low carbon energy technologies (such as nuclear or renewables), carbon sequestration, or improve the efficiency of their current carbon technologies in order to sell surplus permits, or at least minimise their permit purchase requirements. Consumers will be forced by higher prices to reduce their energy demand and/or adopt more efficient appliances and energy use

\footnotetext{
${ }^{2}$ It is not the purpose of this paper to give a critique of the Gittus study, which contains a number of unrealistic assumptions. However, the error noted here is particularly significant in the context of carbon costing.
} 
practices. It should be remembered, however, that the Commonwealth government is not a party to this initiative, so the integrity of the scheme may be compromised by its inability to operate outside of conforming (currently Laborcontrolled) states.

Thus, ironically, the very mechanism that has encouraged excessive environmental damage in much of the world, and hence contributed significantly to its accompanying high social costs - the market place - can be an important avenue by which environmental objectives and targets could be met. However, to do so effectively, both the implicit and explicit subsidies that have contributed to so much of the problem in the first place need to be removed.

\section{Conclusion}

Despite a recent revival of interest in nuclear power, the prospects for private investment in nuclear plant in a liberalised electricity market is unlikely without significant government support. High capital cost, uncertain construction costs, potential delays in construction and licensing, the absence of policies to place a price on $\mathrm{CO}_{2}$ emissions from fossil fuel power plants, and lack of experience and economies of scale in nuclear plant operations are features that would make nuclear power technology particularly unattractive to private investors in Australia. Added to these are public concerns over nuclear safety which could make site selection particularly difficult and expensive if public opposition involves significant delays in the construction and licensing of nuclear power stations.

The over-riding issue, however, is the inability of governments to adopt the PPP in the context of power generation. The advocates of nuclear power have a justifiable argument that its low level of GHG emissions should be attributed a value when considering technologies for new electricity generating capacity, if the costs of meeting $\mathrm{CO}_{2}$ reduction targets are not imposed on the polluters. But politically it appears less problematic to subsidise the non-polluter than tax the polluter.

\section{References}

European Commission (2003), 'External Costs: Research Results on Socio-Environmental Damages Due to Electricity and Transport', EUR 20198, Office for Official Publications of the European Communities, Luxembourg.

Joskow, P. (2006), 'Prospects for Nuclear Power: A US Perspective', Presentation to the University of Paris (Dauphine), 19 May, Available at: http://www.dauphine.fr/cgemp/ Manifestations/joskow\%20conference/geopolitics\%20joskow\%2024\%20mars.pdf\#search $=\% 22$ joskow $\% 20$ nuclear\%20dauphine $\% 22$.

Perman, R., Y. Ma, J. McGilvray and M. Common (2003), Natural Resource and Environmental Economics, 3rd edition, Pearson Education, London. 
Thomas, S. (2005), 'Nuclear Power - Myth and Reality: The Economics of Nuclear Power', Nuclear Issues Paper No. 5, Heinrich Böll Foundation, available at: http://www.boell.de/downloads/oeko/NIP5ThomasEndf.pdf.

Toll, R. (2005), 'The Marginal Costs of Carbon Dioxide Emissions: An Assessment of the Uncertainties’, Energy Policy 33:2064-2074.

The author acknowledges helpful comments provided by two anonymous referees in the preparation of this paper. 


\section{Pharmaceuticals Benefit Scheme: Effects of the Safety Net}

\section{Laurie Brown, Annie Abello and Ann Harding}

$\mathrm{T}$ The aim of the Australian Pharmaceuticals Benefit Scheme (PBS) is to provide Australians with affordable, reliable and timely access to necessary and cost-effective medicines (Department of Health and Ageing, 2005). The Australian PBS has two key policy settings: patient copayments and the 'safety net' (SN). The copayment is the direct out-of-pocket contribution the patient has to pay towards the cost of their medicine — for some drug items, consumers may also have to pay a brand or therapeutic price premium. The PBS SN arrangements 'protect' individuals and families from large overall expenses incurred through high use of PBS medicines within a calendar year. The basic objective of the SN is to cap PBS drug costs to the 'sick' that is, to high users. Its operation is only means tested in the sense that two thresholds exist - a lower threshold for concessional patients and a higher threshold for general patients. Individuals and families who are eligible to access PBS medicines at reduced concessional copayment and SN rates are those who have low incomes and/or are recipients of certain Commonwealth Government pensions and allowances. For concessional patients, the SN threshold has traditionally been set at 52 PBS scripts per year. Once these patients reach the SN, they are no longer required to pay the patient copayment for PBS subsidised items for the remainder of the year. For general patients reaching the $\mathrm{SN}$, the copayment rate is reduced to the lower concessional rate. In his 2005 budget speech, the Federal Treasurer, the Hon. Peter Costello, announced that the SN thresholds would increase for both concessional and general patients from 1 January 2006.

Within this policy context, this paper investigates which Australian families are likely to be high users of PBS medicines and therefore benefit from the PBS safety net arrangements. The proportion of PBS scripts used by concessional and general patients funded under the $\mathrm{SN}$ arrangements is examined and the distribution of scripts and costs across different family types investigated. Previous research has shown that the PBS is highly progressive with major redistributive effects towards the poor (Harding et al, 2004). The benefits of the SN are available to all heavy users of PBS scripts, irrespective of income within each of the concessional and general patient categories. The SN is not primarily an instrument of redistribution but it may have an incidental redistributive effect because the poor generally have lower health status and are relatively high users of PBS medicines (Harding et al, 2004; AIHW, 2006). A secondary aim of the

Laurie Brown is Associate Professor and Research Director (Health), Annie Abello is a Senior Research Fellow, and Ann Harding is Professor and Director of the National Centre for Social and Economic Modelling, University of Canberra. 
paper, therefore, is to identify which Australian families are likely to be impacted by this latest change to the PBS rules and what implications this might have in terms of the PBS acting as a form of indirect social cash transfer.

A microsimulation model of the PBS, known as 'MediSim', is used to investigate the use of PBS medicines by different types of families and consumer and government expenditures. The 2005-06 financial year is simulated under prebudget PBS settings that is, in the absence of the increase in SN thresholds but including annual CPI indexation. A short overview of the policy background is provided in the following section. The MediSim modelling and methods are then described briefly. Results are presented in terms of the simulated PBS outlays and script use by income quintile and family type-lifecycle group. The paper concludes with some comments on the importance of the $\mathrm{SN}$ in protecting Australian families from 'large' out-of-pocket expenditures on PBS medicines and implications of the policy change to increase SN thresholds.

\section{Policy Background}

In 2004-05, Commonwealth Government expenditure on the PBS was $\$ 5.6$ billion or 15 per cent of total Government health expenditure. Historically, government expenditure on the PBS has grown nominally by more than 10 per cent per annum, well above growth in the total health budget or in GDP. Over the next couple of years, increases in government spending on the PBS are expected to be below the long run average growth of the PBS with a projected increase of 5.4 per cent per annum in real terms compared to 3.3 per cent for the total health budget (Department of Treasury, 2005). However, the Government's share of the costs of the PBS has steadily increased over time as PBS policy settings, which largely determine patient contributions, have increased in general only in line with inflation. Currently, the government subsidises patients to the extent of over 80 per cent of total PBS drug costs, with 80 per cent of government outlays going to concessional patients (Brown et al, 2004; Harding et al, 2004).

Patient copayments and SN thresholds are indexed to movements in the CPI from 1 January each year. However, these two policy settings have been the focus of recent budgetary measures aimed at curtailing government expenditure by shifting costs back to consumers. From 1 January 2005, patient copayments increased by 21 per cent as a result of a 2002 proposed federal budget measure that was passed by the Senate in mid-2004 after a 'back-flip' by the federal Labour Party (Harvey, 2005). With this policy change, SN arrangements were 'untouched' in that they increased proportionately with the rise in copayments. However, in the 2005-06 federal budget, the Treasurer announced that the number of prescriptions concessional families would need to reach the SN threshold would increase from 1 January 2006 from the current 52 scripts by two prescriptions each year up to and including 1 January 2009. For general patients, the SN threshold would increase from the current level by the dollar equivalent of two copayments each year from 1 January 2006 to 1 January 2009. The existing annual indexation of the SN thresholds would continue to be applied on top of these increases. 
It was estimated that this measure would generate savings to Government of only $\$ 1.7$ million in 2005-06 but would increase to over $\$ 71.4$ million by 2008-09, representing approximately a one per cent saving in expected Government expenditure in 2008-09. Changes to the SN threshold were viewed by Government as 'helping to maintain the sustainability of the PBS' (Department of Treasury, 2005a).

The cost of medicines whose price fall below the patient copayment levels (known as below-copay medicines) is fully borne by the patient. The cost of below-copay drugs is included in patients' contribution towards the SN. However, the cost of non-PBS listed prescribed medicines (private medicines) is not counted towards the PBS SN. The same concessional or general SN threshold is applied to a family unit whether the unit consists of a single individual, a couple or a family with dependent children. Each family's SN threshold is reset to zero at 1 January each year. The changes in the policy settings are given in Table 1 alongside those used in the modelling.

Table 1: Pharmaceutical Benefits Scheme: Policy Settings 2005-06

\begin{tabular}{l|rrr}
\hline & $1 / 1 / 2005^{a}$ & $\begin{array}{c}1 / 1 / 2006^{a} \\
\text { (after policy change) } \\
\text { dollars }\end{array}$ \\
& \multicolumn{3}{c}{$\begin{array}{c}1 / 1 / 2006^{p} \\
\text { (without policy change) }\end{array}$} \\
\hline Copayment: Concessional & 4.60 & 4.70 & 4.72 \\
Below safety net & 0 & 0 & 0 \\
Above safety net & & & 29.34 \\
Copayment: General & 28.60 & 29.50 & 4.72 \\
Below safety net & 4.60 & 4.70 & 245.42 \\
Above safety net & 239.20 & 253.80 & 897.65 \\
Safety net: Concessional & 874.90 & 960.10 & \\
Safety net: General & & & \\
\hline
\end{tabular}

Note: $\mathrm{a}=$ actual; $\mathrm{p}=$ projected from previous year using CPI growth estimate of 2.6 per cent.

Source: Department of Health and Ageing (2006)

\section{Methods}

Modelling the PBS with 'MediSim'

Microsimulation modelling was used in this study as this technique brings a range of benefits to policy analysis: model databases can mirror the heterogeneity in the population as revealed in large national household surveys; models can replicate the complexity of the policy structures, transfers, and settings under investigation; they can be used to forecast the outcomes of policy changes and to examine the effects of policy changes for narrowly defined groups of individuals, with model estimates providing insight into the distributional impacts of a policy for which 
'real' data are not otherwise available (Creedy, 2001; Brown and Harding, 2002; Brown and Harding, 2005).

MediSim is designed to simulate current and future use and costs of PBS-subsidised medicines, under existing PBS and different policy settings, and the distributional effects of policy changes estimated (see for example Brown et al, 2003; Brown et al, 2004; Harding et al, 2004). The primary utility of the model is its capability to generate government PBS outlays and consumer costs based on various script volume, drug price, patient copayment and safety net assumptions, as well as to estimate the corresponding effects on families belonging to various income and household groups. The conceptual and technical constructs of MediSim are described in detail elsewhere (Abello et al, 2003; Brown et al, 2004; Brown and Harding, 2005; Lymer and Brown, 2006; Abello et al, 2006). MediSim's base dataset comprises a statistically matched ABS National Health Survey (2001) Basic Confidentialised Unit Record File (CURF) with a modified 1998-99 Household Expenditure Survey Basic CURF and various Medicare Australia (formerly Health Insurance Commission) aggregated data sets on PBS script volumes, costs and settings. The statistical matching allowed the creation of synthetic families (ABS NATSEM Technical Working Group, 2004; Abello et al, 2006). As the PBS SN operates at the income unit level, complete information on all family or income unit members' drug usage and expenditure is needed to adequately model this component of the PBS.

The imputation of drug usage is such that scripts in the model's base year (currently 2003-04) match actual data on total scripts by drug class and the distribution of scripts per person, by concession card status, gender and age group. The PBS is modelled by applying the rules of the scheme to each individual and family in the dataset over an 18-month period on a monthly basis, starting on 1 January. To generate out-years - as used in this study - the base population is 'aged' and the script and cost data in the person-level dataset revised each year according to pharmaceutical trends. MediSim generates cost estimates based on a distributional approach to drug pricing to reflect variation existing in prices within each drug class. Consumer costs are derived from patient copayment rates and script volumes and do not include brand or therapeutic price premiums.

\section{Analyses}

Individuals and families reaching the $\mathrm{SN}$, for both concessional and general groups, were identified in the model and their script volumes and costs calculated. Differences by income quintile and selected family type-lifecycle group are reported here (for other breakdowns, see Brown, Abello and Harding, 2005). The new OECD equivalence scale was used to derive income quintile from equivalent disposable annual family income and was calculated separately for concessional and general patients. Family type-lifecycle group is defined in terms of whether or not there are dependent children in the family, whether or not there are one or two adults in the family group, plus age of the head of the family (ABS, 2001). 
The results apply only to families identified in the model as using PBS medicines in the 2005-06 outyear. Of the 3.91 million families with concessional status in the model, representing a total population of 6.91 million persons, nearly all families and individuals used PBS medicines (98 per cent and 94 per cent respectively). For the 6.44 million families without concessional entitlements, only 40 per cent of families were identified as PBS-users. Because many of these 'families' are sole person income units, only 24 per cent of all general patients in MediSim were identified as using PBS medicines in the 12-month simulation.

\section{Estimated Script Volumes and Costs}

MediSim predicted 171.6 million scripts would be subsidised under the PBS at a total cost of \$6.6 billion if PBS settings remained unchanged in 2005-06 (apart from the normal CPI indexation) (Table 2). Government provides 82 per cent of the total expenditure. Nearly 90 per cent of the costs of the 143.6 million scripts used by concessional families are met by the Government but only 62 per cent of the cost of the 28.1 million scripts used by general patients. Of all scripts used by concessional families, 24 per cent reach the SN compared with 20 per cent for non-concessional families. Concessional families reaching the concessional SN received 61 per cent of total government outlays for all concessional families. The SN reduced these families' out-of-pocket costs by $\$ 159.7$ million (average copayment 'multiplied by' above-SN scripts). This is equivalent to two-thirds of the estimated contribution these families make to the cost of their PBS medicines. The SN effectively reduces the average script cost for concessional families from $\$ 4.64$ for non-SN households to \$2.82 for SN households.

Table 2: MediSim Estimates of PBS Scripts and Costs, 2005-06

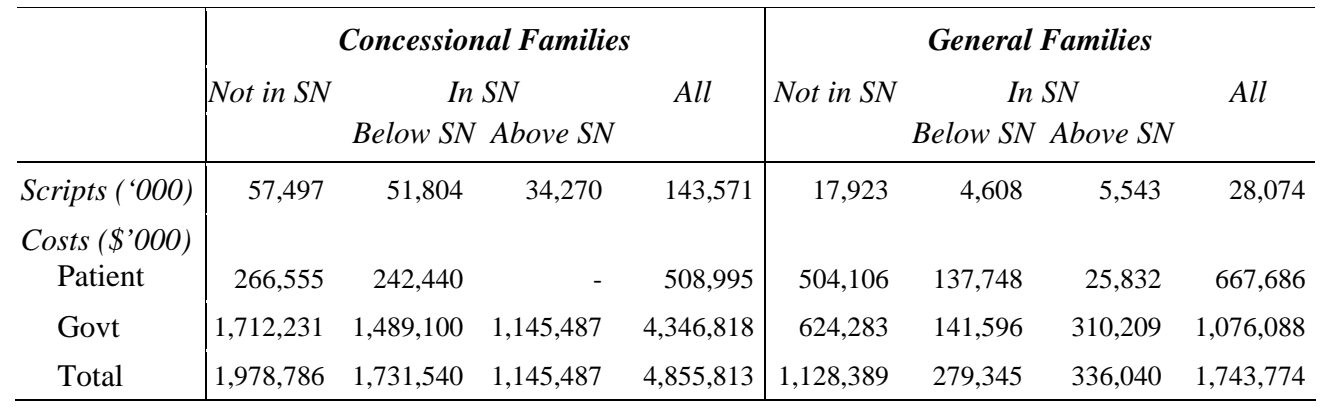

Families without concessional status reaching the general patient SN received 42 per cent of government outlays on scripts for non-concessional families. The SN saved general patients \$160.6 million which nearly matched these families' direct contributions to costs. The SN effectively reduced the average script cost for general families from over $\$ 28.00$ for non-SN households to $\$ 16.11$ for SN families. General patient families reaching the SN also benefit from the Government 'picking up the tab' for any below copay medicines whose price falls between the general copayment and the concessional copayment that they pay 
over the remainder of the year. The size of this subsidisation is unknown. But which Australian families are reaching the SN and benefiting from increased government subsidisation?

\section{Distributional Impacts of the PBS Safety Net}

\section{Income quintile}

The SN may be interpreted as distribution neutral if the income distribution of SN families is the same as the income distribution of non-SN families. The distribution of SN and non-SN families is similar for the general population but, for the concessional population, the SN appears to be non-neutral with a skew toward the second-bottom and middle quintiles (Table 3). For example, 33 per cent of the second poorest and 44 per cent of middle income quintile concessional families reach the SN in the modelling. These families receive the greatest share of all government expenditure on the PBS (13.2 per cent and 11.5 percent of government outlays respectively). However, in terms of Government subsidisation as a proportion of family annual disposable income then Government outlays are most important for the poorest 40 per cent of concessional families who reach the SN - the government subsidy they receive on their PBS medicines is equivalent to $17-18$ per cent of their family income. This is important because family spending on PBS subsidised medicines per year is on average 2.5 times higher for families reaching the SN than families not reaching the SN. This occurs for both families with and without concessional status.

For non-concessional families, approximately 11 per cent of families in each income quintile reach the SN. In Table 3, family expenditure per year on PBS medicines for non-concessional families reaching the $\mathrm{SN}$ is below the $\mathrm{SN}$ threshold given in Table 1 for general patients. This gap reflects the 'unknown' out-of-pocket expenditure on below copay drugs which contributes to a family's overall expenditure permissible under the SN arrangements.

\section{Family type-lifecycle group}

Table 4 presents the modelling results for selected types of families. The proportion of families reaching the SN threshold varies substantially across these groups. Very few sole parent families, irrespective of concessional status, benefit from the SN arrangements. For those sole parent families reaching the SN, the Government outlay on their PBS medicines is important when seen as a proportion of annual family disposable income. For concessional families, only 18 per cent of couples with children are expected to reach the SN compared with 28 per cent of older single persons and 67 per cent of older couples without children. In comparison, for general patient families, 10 per cent of 'couples with children' families will reach the SN, 23 per cent of older single persons and 43 per cent of older couples without children. Young singles and couples do not generally reach SN thresholds whether or not they are concession cardholders (only 1-2 per cent of these families reach SN levels of PBS medicine use). 


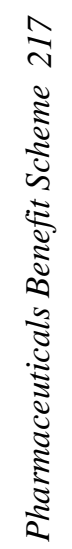

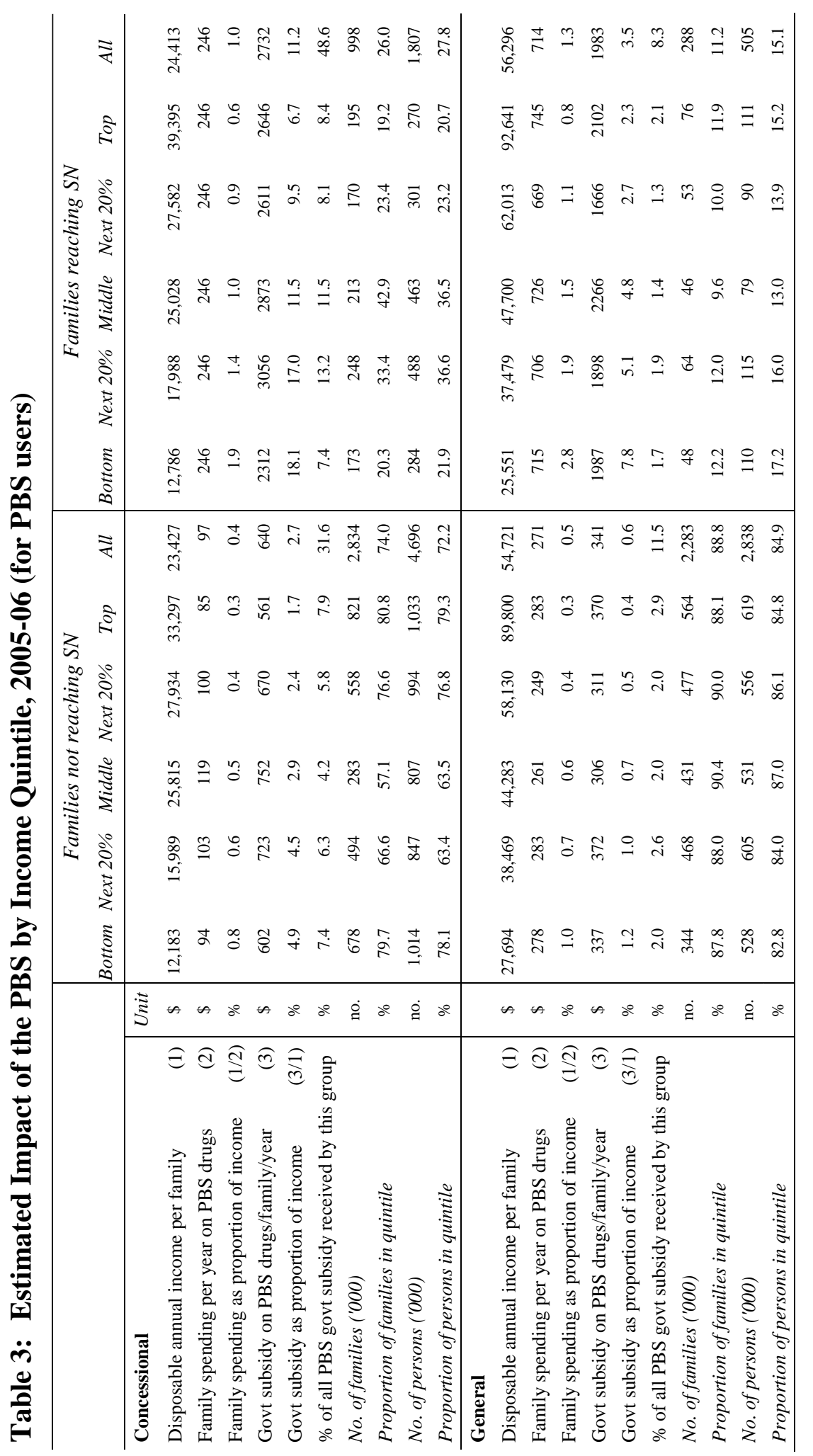




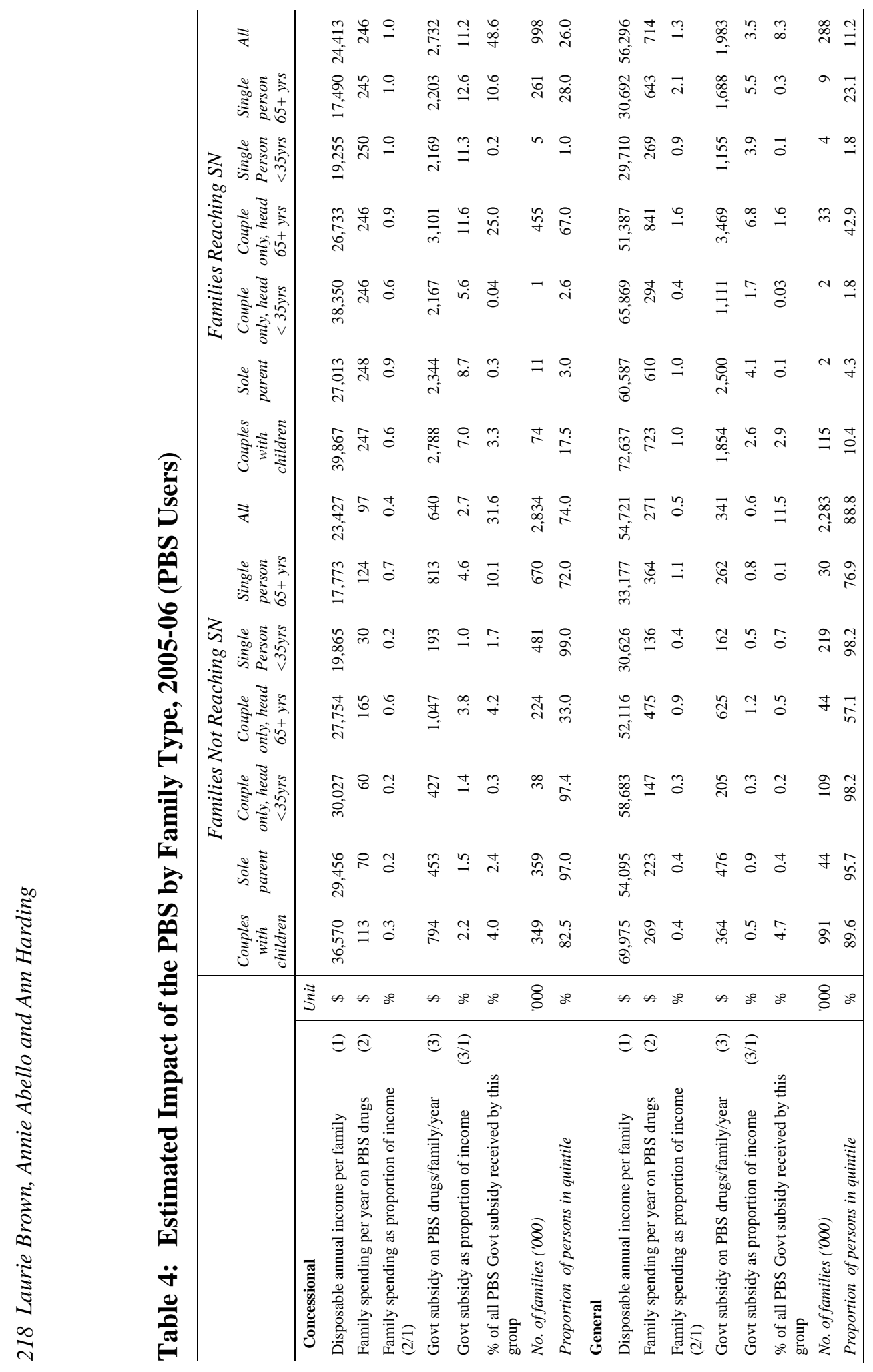


'Couples only with the head of the household aged 65 years or over' who are concessional cardholders and who reach the SN receive a quarter of the total government outlay on PBS subsidised medicines. Older single persons who reach the SN under concessional arrangements also receive a high share of all government outlays at 10.6 per cent. Given their annual disposable incomes, government subsidisation of medicines is very significant for these older Australians who require large numbers of scripts per year.

Non-concessional 'couple only families with the family head aged 65 years or over', on average, make the greatest absolute out-of-pocket contribution to the costs of PBS medicines at an estimated $\$ 841$ for the year. This represents 1.6 per cent of their annual disposable income and is second to the relative patient contributions from single general patients aged 65 years or over (2.1 per cent).

\section{Health needs}

Differences in the health characteristics of Australian families underlie these script use and expenditure patterns. Tables 5 and 6 provide information on two basic health indicators - estimated average number of long-term health conditions and average self-assessed health status - for adults in each family type.

Table 5: Health Indicators by Income Quintiles

\begin{tabular}{|c|c|c|c|c|}
\hline & \multicolumn{2}{|c|}{ Families not reaching $S N$} & \multicolumn{2}{|c|}{ Families reaching $S N$} \\
\hline & $\begin{array}{c}\text { Ave. no. long term } \\
\text { health conditions }\end{array}$ & $\begin{array}{r}\text { Average SAHS } \\
\text { pe }\end{array}$ & $\begin{array}{l}\text { Ave. no. long } \\
\text { term health } \\
\text { conditions } \\
\text { dult }\end{array}$ & Average SAHS \\
\hline \multicolumn{5}{|l|}{ Concessional } \\
\hline Bottom 20\% & 2.5 & 2.8 & 5.4 & 3.8 \\
\hline Next $\quad 20 \%$ & 2.5 & 3.1 & 4.7 & 3.6 \\
\hline Middle 20\% & 2.1 & 2.7 & 4.4 & 3.5 \\
\hline Next $\quad 20 \%$ & 2.3 & 2.6 & 5.2 & 3.5 \\
\hline Top $\quad 20 \%$ & 2.3 & 2.5 & 4.8 & 3.3 \\
\hline All & 2.4 & 2.7 & 4.8 & 3.5 \\
\hline \multicolumn{5}{|l|}{ General } \\
\hline Bottom 20\% & 1.5 & 2.3 & 3.3 & 3.2 \\
\hline Next $\quad 20 \%$ & 1.6 & 2.4 & 3.4 & 3.1 \\
\hline Middle 20\% & 1.6 & 2.4 & 3.7 & 3.2 \\
\hline Next $\quad 20 \%$ & 1.6 & 2.2 & 3.2 & 2.8 \\
\hline Тор & 1.6 & 2.2 & 3.1 & 2.7 \\
\hline All & 1.6 & 2.3 & 3.3 & 3.0 \\
\hline
\end{tabular}

Note: SAHS $=$ self assessed health status on a scale of 1 to 5 where $1=$ excellent and $5=$ poor. 
Table 5 confirms several major health trends: a) the presence of socioeconomic differentials in health with the number of long-term health conditions increasing and self assessed health status decreasing with declining income; b) adults entitled to concessional status have significantly worse health status on average than general patients; and c) the health status of the adults in families reaching the SN is worse than that of adults in families not using large PBS script volumes. The latter two trends also are evident in all of the family types studied (Table 6). Both young and old single adults with concession cards who have high use of PBS medicines appear to do so because they have poor health status. What is concerning is that sole parents with concessional status and whose families reach the SN also have poor health status relative to other Australian adults, averaging 5.2 long-term health conditions each and a self-assessed health status of 3.5 .

Table 6: Health Indicators by Family Type — Lifecycle Group

\begin{tabular}{|c|c|c|c|c|c|c|}
\hline & $\begin{array}{l}\text { Couple with } \\
\text { children }\end{array}$ & $\begin{array}{c}\text { Sole } \\
\text { parent }\end{array}$ & $\begin{array}{l}\text { Couple only, } \\
\text { head }<35 \text { yrs }\end{array}$ & $\begin{array}{l}\text { Couple only, } \\
\text { head } 65+\text { yrs }\end{array}$ & $\begin{array}{l}\text { Single Person } \\
\quad<35 \text { yrs }\end{array}$ & $\begin{array}{l}\text { Single Person } \\
\quad 65+y r s\end{array}$ \\
\hline & \multicolumn{6}{|c|}{ per adult } \\
\hline \multicolumn{7}{|l|}{ Concessional } \\
\hline \multicolumn{7}{|l|}{ Not-Reaching SN } \\
\hline Ave no. of LT conditions & 1.8 & 1.9 & 1.7 & 2.3 & 1.8 & 3.0 \\
\hline Average SAHS & 2.6 & 2.5 & 2.2 & 2.5 & 2.5 & 2.9 \\
\hline \multicolumn{7}{|l|}{ Reaching SN } \\
\hline Ave no. of LT conditions & 3.4 & 5.2 & 4.0 & 4.3 & 5.1 & 5.8 \\
\hline Average SAHS & 3.6 & 3.5 & 3.2 & 3.4 & 3.9 & 3.6 \\
\hline \multicolumn{7}{|l|}{ General } \\
\hline \multicolumn{7}{|l|}{ Not-Reaching SN } \\
\hline Ave no. of LT conditions & 1.5 & 1.7 & 1.3 & 2.3 & 1.3 & 2.4 \\
\hline Average SAHS & 2.3 & 2.1 & 2.1 & 2.3 & 2.2 & 2.6 \\
\hline \multicolumn{7}{|l|}{ Reaching SN } \\
\hline Ave no. of LT conditions & 2.5 & 2.7 & 2.7 & 3.9 & 4.8 & 4.6 \\
\hline Average SAHS & 2.8 & 2.4 & 2.6 & 3.1 & 2.8 & 3.2 \\
\hline
\end{tabular}

Note: SAHS $=$ self assessed health status on a scale of 1 to 5 where $1=$ excellent and $5=$ poor.

\section{Discussion and Conclusions}

The Government is anticipating saving $\$ 140.3$ million over the next four years by increasing the PBS SN thresholds. With only six months implementation combined with the pattern of use of PBS medicines across the year, the effect of the higher SN arrangements on the distribution of costs between government and consumers is not yet clear. Families typically reach the SN towards the end of a calendar year and it appears that both concessional and general patients 'stocked-up' on PBS medicines before the introduction of the SN budget measure on 1 January 2006 - the proportion of scripts above SN was slightly higher in July-Dec 2005 than the same period in 2004 for both concessional (37.2 vs 36.6 per cent) and general patients (30.2 vs 28.7 per cent) (Medicare Australia, 2006). 
The PBS helps to alleviate the financial pressure faced by many Australian families in accessing prescribed medicines. This modelling has shown that government outlays on the PBS are targeted to low income families, those with concessional status, and elderly couple or elderly single person families with no dependent children. The SN plays an important function in capping costs for many families. Of those concessional families using PBS medicines, one in four are likely to reach the SN threshold while one in ten families without concessional entitlements are likely to. Concessional families who are likely to reach the concessional SN threshold are estimated to receive three-fifths of government outlays on concessional patients while families without concessional status reaching the general patient SN receive two-fifths of government outlays on scripts for general families. The proportion of families expected to reach the SN does vary, however, by income for concessional families, and family typelifecycle group for both concessional and general populations, indicating the presence of some redistributive effects.

Differences in the health characteristics of these groups underlie the script and expenditure patterns reported. There are strong socio-economic and life-cycle differentials in health status with the number of long-term health conditions rising and self-assessed health status declining with decreasing family income and increasing age. The results presented in this paper indicate that the SN is operating as intended. That is, it is supporting families that have relatively poorer health status - at least the adults - and who otherwise may struggle in paying for medicines they need. For these families, government subsidisation of the cost of PBS medicines represents a significant social cash transfer. For a number of concessional family groups, government spending per family equates to in excess of 10 per cent of their annual disposable income.

Changes to the SN arrangements will be felt by these families. For families to reach the SN thresholds, they have had to make the effort to record their use of medicines and keep track of their out of pocket expenditure. Unlike the Medicare safety net, there is no formal method of recording family expenditure on PBS items and whether or not they have reached the PBS SN. Rather, the responsibility for recording patient payments in order to access the SN copayment rates rests with the consumers themselves. This research indicates that there is a strong economic incentive for many Australian families to record their family spending on pharmaceuticals.

As seen in this paper, Government outlays on the PBS are 'pro-poor' and 'pro-sick'. However, families who appear to be least able to afford to pay for medicines themselves and least able to meet such cost-shifting are being asked to generate the proposed savings from the changes to the SN. While for concessional patients, an additional two scripts per year superficially does not seem significant, such a measure potentially could restrict access to medicines and result in some patients not filling their scripts - it has already been seen that the increase in patient copayments in 2005 has reduced demand for PBS subsidised medicines. This could have unintended consequences which could ultimately cost the 
government more than it saves (Donovan, 2002; Harvey 2002; Harvey, 2005). Also as the Pharmacy Guild of Australia (2005) reported:

the new provisions also [will] affect 'general' medicines consumers. For them, the safety net threshold in 2006 will move close to $\$ 1,000$, incorporating the regular CPI increase. This is a significant raising of the bar, and will make it more difficult for families who are sick and need a lot of medicines to reach the safety net.

Models such as MediSim provide policy-makers with decision-support tools that can be used to help evaluate policy options. Testing the distributional impacts of different scenarios based on different SN threshold/co-payment selections, especially within the context of the health outcomes generated from the expenditure on the PBS, would assist in identifying whether or not current investment in the health and well-being of Australian families through the PBS is appropriate or 'optimal' in terms of economic effectiveness, efficiency and social equity. This policy debate will become increasingly pressing with population ageing and rising demand for new medical technologies. The 'artificial' data of MediSim can be usefully combined with real data on drug costs, quality use of medicines and health outcomes, for example, to help inform the debate on the long term affordability and equity of PBS - which up to now has been regarded as one of the best pharmaceutical systems in the world.

\section{References}

Australian Bureau of Statistics (2001), Government Benefits, Taxes and Household Income, Australia, Cat. No. 6537.0, Canberra.

Australian Bureau of Statistics (2003), National Health Survey: User's Guide, 2001, Catalogue No. 4363.0.55.001, Canberra.

Australian Institute of Health and Welfare (2006), Australia's Health, 2006. AIHW Cat. No. 73, Canberra.

ABS-NATSEM Technical Working Group Collaboration on Statistical Matching (2004), 'Statistical Matching of the HES and NHS: An Exploration of Issues in the Use of Unconstrained and Constrained Approaches in Creating a Basefile for a Microsimulation Model of the Pharmaceutical Benefits Scheme', ABS Methodology Advisory Committee Paper, June.

Abello, A., S. Lymer, B. Phillips and A. Harding (2006), 'Enhancing the Australian National Health Survey Data for Use in a Microsimulation Model', paper prepared for the 29th General Conference of the International Association for Research in Income and Wealth, Joensuu, Finland, 20-26 August.

Abello, A., L. Brown, A. Walker and T. Thurecht (2003), 'An Economic Forecasting Microsimulation Model of the Australian Pharmaceutical Benefits Scheme', NATSEM Technical Paper No. 30, University of Canberra. 
Brown, L. and A. Harding (2005), Chapter 10 in Productivity Commission, 'The New Frontier of Health and Aged Care, Quantitative Tools for Microeconomic Policy Analysis', Conference Proceedings (17-18 November, 2004), Canberra.

Brown, L, Abello, A and Harding, A (2005), 'Distributional Impacts of the Pharmaceutical Benefits Scheme's Safety Net', paper presented at the Australian Health Economists' Conference, Auckland, 29-30 September.

Brown, L., A. Abello, B. Phillips and A. Harding (2004), 'Moving Towards an Improved Micro-Simulation Model of the Australian Pharmaceutical Benefits Scheme', Australian Economic Review 37(1):41-61.

Brown, L., A. Abello, B. Phillips and A. Harding (2003), 'The Australian Pharmaceuticals Benefit Scheme and Older Australians: Changes in Government Outlays and Consumer Costs from the 2002-03 Federal Budget Measures', International Microsimulation Conference on Population, Ageing and Health, Canberra, December.

Brown, L. and A. Harding (2002), 'Social Modelling and Public Policy: Application of Microsimulation Modelling in Australia', Journal of Artificial Societies and Social Simulation 5(4), http://jasss.soc.surrey.ac.uk/5/4/6.html.

Creedy, J. (2001), ‘Tax modelling’, Economic Record 77(237):189-202.

Department of Health and Ageing (2005), 'Budget Related Paper No. 1.11' 2005-06 Portfolio Budget Statements, Commonwealth of Australia, Canberra.

Department of Health and Ageing, (2006), http:/www.health.gov.au/internet/wcms/ publishing.nsf/Content/health-pbs-general-pbs-phbensna.htm-copy2.

Department of the Treasury (2005), 'Budget Strategy and Outlook 2005-06', Budget Paper No. 1, Commonwealth of Australia, Canberra.

Department of the Treasury (2005a), 'Expense Measures - Health and Ageing', Budget Paper No 2, Part 2, Commonwealth of Australia, Canberra.

Donovan, J. (2002), 'The Benefits of the PBS to the Australian Community and the Impact of Increased Copayments’, Health Issues 71:1-8.

Harding, A., A. Abello, L., Brown and B. Phillips (2004), 'The Distributional Impact of Government Outlays on the Australian Pharmaceutical Benefits Scheme in 2001-02', Economic Record 80(Special Issue):S83-S96.

Harvey, K. (2002), 'Securing the Future of the Pharmaceutical Benefits Scheme? The Drawing Board', in 'The 2002-03 Federal Budget', An Australian Review of Public Affairs, Symposium, June.

Harvey, K. (2005), 'The Pharmaceutical Benefits Scheme 2003-04', Australia and New Zealand Health Policy 2(1):2-5.

Lymer, S. and L. Brown (2006), 'The Methodological Issues of Using Cross-Sectional Data for Pharmaceutical Health Outcome Analysis’, NATSEM Technical Paper TP31, University of Canberra. 
Medicare Australia (2006), http://www.medicareaustralia.gov.au/providers/health_ statistics/statistical_reporting/pbs.htm.

Pharmacy Guild of Australia (2005), 'Budget Will Add \$327 Million to PBS’, Media Release, Canberra, 10 May.

The construction of the current version of the 'MediSim' model was supported by an Australian Research Council linkage grant (no. LP0219571), and by Medicines Australia, the Industry Partner to this grant. The authors thank Brendan Shaw, Senior Manager, Policy and Research, Medicines Australia and members of the Pharmaceutical Economic Taskforce of Medicines Australia for their advice and input on the modelling, Sharyn Lymer, Senior Research Fellow, NATSEM, for her advice and assistance in the methodological construction of the model, and two anonymous referees for valuable comment. 


\section{Has Foreign Capital Made us Richer?}

\section{Tony Makin}

A ustralia's current account deficit approached seven per cent of GDP in 2004-05, one of its highest ever levels, renewing concerns in financial markets and economic policy circles about the sustainability of the economy's balance of payments (see Edwards, 2005, Swan, 2005). External deficits of similar magnitude relative to GDP have recently been experienced by the United States, New Zealand and to a lesser extent by the United Kingdom. These deficits have been largely funded by high saving economies in East Asia, especially Japan and China, and oil exporting nations (see MacFarlane, 2005; International Monetary Fund, 2005).

Financial market traders and policymakers worry that current account deficits of this size reflect poor international trade performance; that imports are too high and exports are too low. In addition, escalating external debt levels are considered inherently risky because over-reliance on foreign funds exposes an economy to sudden shifts in international investor sentiment and hence to capital flow reversals that could precipitate a currency and financial crisis, spark high inflation and induce a major recession (see, amongst others, Mann, 2002; and Fischer, 2003).

The significance of current account deficits has been a long-running theme in Australian economic policy debate. As argued previously (Makin, 1989) at a time when the balance of payments was the central macroeconomic issue, external deficits are often best interpreted as saving-investment imbalances that allow real domestic capital accumulation to proceed more quickly. As a counter to concerns about external imbalances, it can therefore be argued that external deficits and matching capital account surpluses should actually be welcomed since they allow real investment to be higher. Similarly, in stock terms when foreign funds finance expansion of the domestic capital stock, the rise in external liabilities is matched by an increase in the level of productive plant, equipment and buildings.

In sum, irrespective of its form net capital inflow allows more domestic capital accumulation which, if used for this purpose, improves the economy's overall productive capacity. Numerous theoretical approaches have previously been advanced to demonstrate this (see, amongst others, Frenkel and Razin, 1987; McDougall, 1960; Grubel, 1987; Ruffin, 1987; and Makin, 2003).

In the resurgent economic policy debate about Australia's external imbalance, an important question not yet asked nor answered is: By how much has foreign capital raised Australia's living standards? Or, in other words, how much better off, income-wise, have persistent current account deficits and rising foreign debt levels made us? 
This paper addresses that question by providing estimates of national income gains attributable to capital inflow for the period 1995-96 to 2004-05. First however, it highlights the behaviour of saving and investment as influences on external account outcomes. It then proposes a straightforward method for understanding how capital inflow improves national income before estimating the national income gains that have accrued from the use of foreign capital over the past decade.

\section{Saving, Investment and the External Imbalance}

Australia's current account deficit has averaged 4.5 per cent of GDP since the early 1990s and on this measure has been one of the largest long-running deficits in the world. Historically, these imbalances have resulted from the nation's status as a relatively low saving economy, yet one that persistently invests comparatively more than other comparable economies (see Figure 1).

External imbalances have been the measured equivalent of the excess of domestic investment (expenditure by the private and public sectors on fixed assets including machinery and equipment, dwellings, non-dwellings, roadworks and livestock) over relatively more stable domestic saving, as shown in Figure 1. This figure also reveals how much extra domestic investment capital inflow has financed over and above that funded by domestic saving. Moreover, since saving has been relatively stable, the bulk of variation in the external imbalance has been due to fluctuation in investment.

A significant portion of gross saving is devoted to capital consumption, or depreciation. However, annual saving-investment gaps still have the same value shown in Figure 1 when capital consumption is subtracted from the depicted gross saving and investment measures. Net domestic saving has remained positive since the early 1990s and was around five percent of GDP in 2004-05. Capital inflow therefore funded extra capital accumulation of the same value as the external imbalance.

It may be argued that the conventional saving measure is understated if unadjusted for alternative expenditure concepts. For example, expenditure on education, research and development, certain defence equipment and consumer durables (treated as consumption expenditure in the national accounts) may be treated as investment as they contribute to future production of goods and services.

If such expenditure is reclassified as investment, measures of either gross or net domestic saving and investment would rise accordingly (see Australian Bureau of Statistics, - ABS, 2002). Again however, the difference between adjusted saving and investment would equate to the same-sized external imbalance derived from the conventional saving measure.

High current account deficits have raised net foreign debt from 35 per cent of GDP at the beginning of the 1990s to around 50 per cent at the end of 2004. The private sector owns nearly all of this debt and around 80 per cent of external borrowing is intermediated through financial institutions, mainly the major commercial banks. 
Figure 1: Saving, Investment and the External Imbalance: Australia vs OECD Average
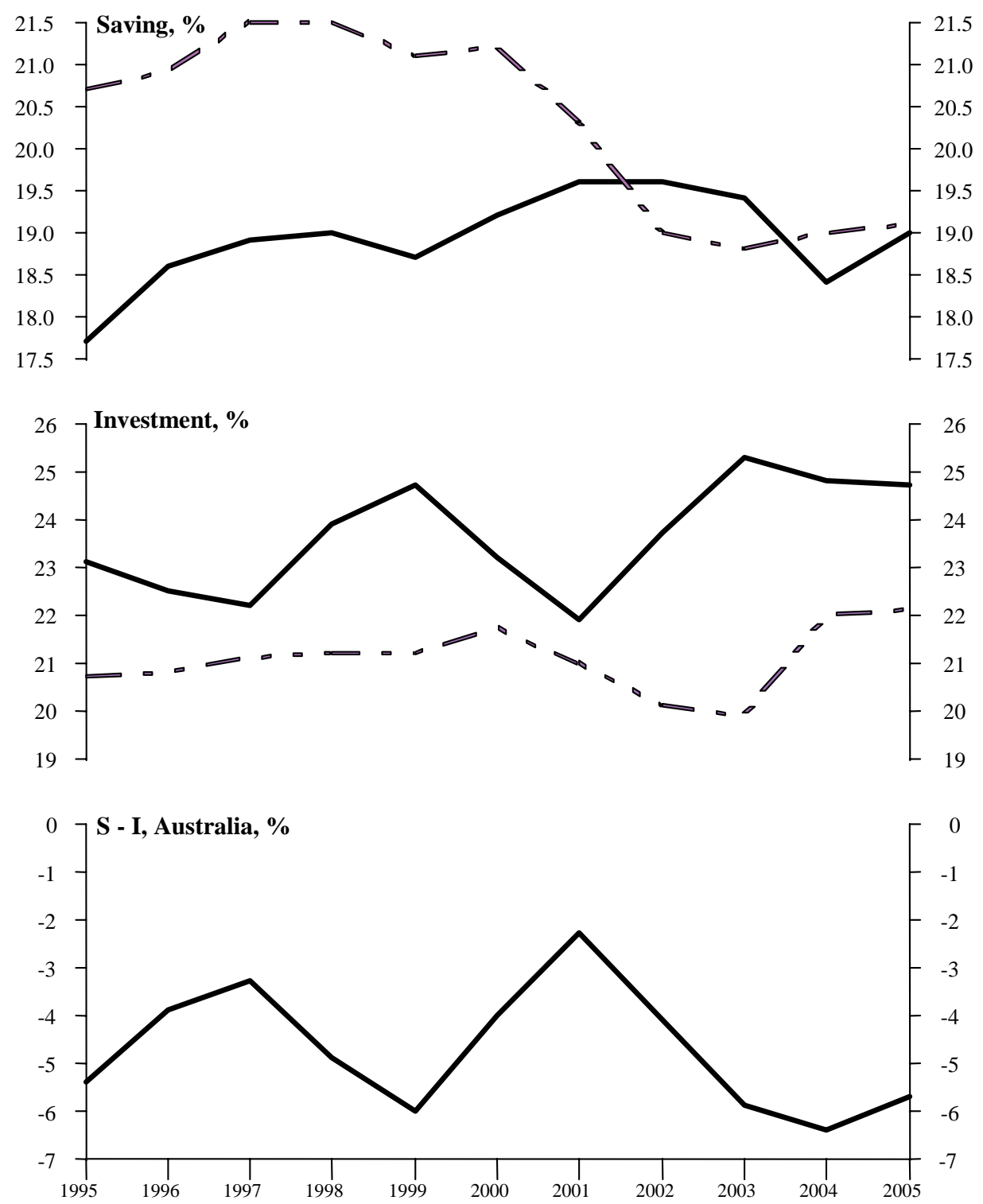

Source: Data from International Monetary Fund, World Economic Outlook (various years) 
Meanwhile, net external equity inflows increased net external liabilities to 65 per cent of GDP. Although Australia now has a high level of external liabilities to the rest of the world, a much greater rise in private wealth due to capital accumulation and valuation gains have ensured that net external liabilities are still only around 10 per cent of the total value of residents' assets.

\section{National Income Gains from Foreign Capital}

If Australia's external imbalances signify additional capital accumulation, how does this affect economic growth? This depends on the relationship between domestic saving, foreign investment, domestic investment and the production process.

When foreigners finance expansion of the domestic capital stock, the rise in external liabilities is also matched by an increase in the nation's real assets. In short, foreign investment supplements domestic saving, allowing an economy to accumulate real capital more quickly. Without that capital inflow over past decades, the combined saving of the private and public sectors would have yielded lower investment and hence lower real output growth.

Therefore, the question of the desirability of a current account deficit, which necessarily matches a net capital inflow, essentially depends on whether the extra real output made possible by foreign finance exceeds the real servicing cost on that source of finance.

Standard growth accounting (see Solow, 1956; 1957) suggests that to understand how national output and income grow, it is necessary to focus on the main factor inputs to economy-wide production. Conventionally, these factor inputs have been the domestic labour force, the domestic capital stock and multifactor productivity, inclusive of disembodied technological change.

Within a traditional growth accounting framework, a distinction can be made between home-funded and foreign-funded capital accumulation for financially open economies. In international borrower economies the real capital stock comprises capital funded by domestic saving and additional capital accumulated via external borrowing.

Hence, in an open economy the macroeconomic production function may be specified as

$$
Y=f\left(A, K, K^{*}, L\right)
$$

where $Y$ is national output or $G D P, A$ is a technology parameter representing disembodied technical change, $K$ is domestically funded capital accumulation, $K^{*}$ is foreign-financed investment and $L$ is labour hours worked.

By totally differentiating this open economy production function, the sources of increased gross domestic product are shown to be

$$
d Y=f_{A} d A+f_{K} d K+f_{K^{*}} d K^{*}+f_{L} d L
$$

where $f_{A, K, K^{*}, L}$ denotes the derivative of $Y$ with respect to $A, K, K^{*}, L$. 
For economies that are net borrowers, national output and national disposable income diverge to the extent of net income paid abroad. Hence,

$$
Y_{n}=Y-r^{*} K^{*}
$$

where $Y_{n}$ is national disposable income and $r^{*}$ is the effective servicing cost of foreign capital (inclusive of dividends) on external liabilities. So,

$$
d Y_{n}=d Y-\left(r^{*} d K^{*}+d r^{*} K^{*}\right)
$$

The effective interest rate paid to foreigners may vary from interval to interval as world interest rates fluctuate or as any risk premium varies through time.

From (2) and (4), the sources of national income growth can therefore be shown as

$$
d Y_{n}=\left\{f_{A} d A+f_{L} d L+f_{K} d K\right\}+\left\{f_{K^{*}} d K^{*}-\left(r^{*} d K^{*}+d r^{*} K^{*}\right)\right\}
$$

The first set of braces captures the domestic sources of growth whereas the second set includes the foreign sources of central interest. Hence, national income gains can be attributed to domestic sources, $d Y_{n}^{d}$, and foreign sources, $d Y_{n}^{f}$, such that

$$
d Y_{n}=d Y_{n}^{d}+d Y_{n}^{f}
$$

Dividing through by national income, National Income Growth = Domestic Contribution + Foreign Contribution $(7)$

To estimate the net contribution of foreign capital, it is necessary to derive values in real terms for each of the variables in the expression

$$
\left(f_{K^{*}}-r^{*}\right) d K^{*}-d r^{*} K^{*}
$$

where $K^{*}$ represents the capital funded from abroad.

Since most capital inflow is intermediated through the commercial banking system, it is reasonable to assume that the productivity of capital in use domestically is invariant to the source of its funding. Therefore,

$$
f_{K}=f_{K^{*}}
$$

Next, we assume output is generated by a Cobb-Douglas function of the form

$$
Y=A K^{\alpha} L^{1-\alpha}
$$

where $\alpha$ is the share of capital in national income.

The Cobb-Douglas function remains a popular specification of the production process in international studies and this form is appropriate if the division of national income between capital and labour has been roughly constant over an extended period of time. As we will see shortly, this indeed has been the experience for Australia over the past decade.

When differentiated with respect to capital, the Cobb-Douglas production function yields

$$
f_{K}=\alpha A K^{\alpha-1} L^{1-\alpha}
$$

Dividing (10) by $K$, 


$$
\frac{Y}{K}=A K^{\alpha-1} L^{1-\alpha}
$$

Hence,

$$
f_{K}=\alpha A K^{\alpha-1} L^{\alpha-1}=\alpha \frac{Y}{K}
$$

The marginal product of capital in use domestically is therefore the income share of capital in GDP times the ratio of national output to capital.

\section{Estimates of National Income Gains}

Using the comprehensive flow and stock data from the national accounts, it is possible to derive annual values of the marginal product of capital for each of the past ten years using expression (13). The data required for this purpose are included in Table 1.

\begin{tabular}{|c|c|c|c|c|c|c|c|}
\hline & $\begin{array}{c}\text { Real } \\
\text { Capital } \\
\text { Stock }(a)\end{array}$ & $\begin{array}{l}\text { Real } \\
\text { GDP } \\
\text { (b) }\end{array}$ & $\begin{array}{l}\text { Output/ } \\
\text { Capital } \\
\text { Ratio(c) }\end{array}$ & $\begin{array}{l}\text { Capital } \\
\text { Share } \\
\text { (d) }\end{array}$ & $\begin{array}{l}\text { Marginal } \\
\text { Product of } \\
\text { Capital (e) }\end{array}$ & $\begin{array}{c}\text { Capital } \\
\text { Consumption } \\
(f)\end{array}$ & $\begin{array}{c}\text { Net Marginal } \\
\text { Product of } \\
\text { Capital }(g)\end{array}$ \\
\hline Year & $(\$ b)$ & $(\$ b)$ & & $(\%)$ & & $(\%)$ & $(\%)$ \\
\hline $1995-96$ & 1806.0 & 621.8 & 0.34 & 0.39 & 13.3 & 4.7 & 8.5 \\
\hline 1996-97 & 1857.6 & 646.0 & 0.35 & 0.37 & 12.9 & 4.7 & 8.2 \\
\hline $1997-98$ & 1918.2 & 674.9 & 0.35 & 0.38 & 13.5 & 4.8 & 8.7 \\
\hline 1998-99 & 1981.0 & 709.9 & 0.36 & 0.38 & 13.5 & 4.9 & 8.6 \\
\hline 1999-00 & 2050.6 & 738.1 & 0.36 & 0.38 & 13.7 & 5.0 & 8.8 \\
\hline 2000-01 & 2098.5 & 752.4 & 0.36 & 0.38 & 13.7 & 5.0 & 8.7 \\
\hline 2001-02 & 2155.6 & 780.8 & 0.36 & 0.39 & 14.1 & 5.1 & 8.9 \\
\hline 2002-03 & 2231.8 & 806.2 & 0.36 & 0.39 & 14.1 & 5.2 & 8.9 \\
\hline 2003-04 & 2318.3 & 838.3 & 0.36 & 0.40 & 14.4 & 5.2 & 9.2 \\
\hline 2004-05 & 2407.9 & 857.8 & 0.36 & 0.40 & 14.3 & 5.2 & 9.1 \\
\hline
\end{tabular}

Table 1: Estimating Marginal Product of Capital, 1995-96 to 2004-05

Notes:

$\mathrm{a}=$ capital stock chain volume data in 2003-04 prices from ABS (2005:83, Table 69).

$\mathrm{b}=$ GDP chain volume data in 2003-04 prices from ABS (2005:16, Table 2).

$\mathrm{c}=$ ratio of the real capital stock to real gross domestic product.

$\mathrm{d}=$ ratio of gross operating surplus to the sum of compensation of employees and gross operating surplus; data from ABS (2005:26, Table 12).

$\mathrm{e}=$ product of the output-capital ratio and the capital share of income.

$\mathrm{f}=$ estimated as the ratio of chain volume measures of consumption of fixed capital to end-year capital stock; data from ABS (2005:84, Table 69).

$\mathrm{g}=$ difference between the marginal product of capital and the estimated depreciation rate. 
These data reveal minimal variation in the output/capital ratio and in the income share of capital in GDP, although there was a slight rise in the rate of capital consumption. Capital consumption now accounts for over half of gross investment and the higher rate of depreciation most likely reflects more intensive use of computers and information technology whose write-off period has diminished as innovation has intensified.

From equation (13), the marginal product of capital results from multiplying the capital share of income and output/capital ratio. Net of depreciation, this yields annual values within the narrow range 8.2-9.2 per cent over the decade. These real values (in constant 2003-04 prices) can then be combined with estimates of the real effective cost of foreign capital and the real external imbalance to yield real annual national income gains attributable to foreign capital.

To estimate the real servicing cost of capital, it is first necessary to derive implicitly the nominal effective cost of foreign capital using balance of payments and international investment position data. The implicit foreign interest rate is net interest paid abroad, as recorded in the current account balance, divided by the stock of net external debt as shown in Figure 2.

International evidence suggests that interest paid abroad is positively related to the stock of foreign debt giving rise to a risk premium (Orr, Edey and Kennedy, 1995; and Lane and Milesi-Ferretti, 2002). A rising risk premium in Australia's case would, other things equal, increase interest paid abroad and hence be reflected in the implicit foreign interest rate.

Apart from debt, external liabilities are in the form of equities serviced through dividends and the profits of branches of transnational companies. Hence, to derive the total effective cost of foreign capital these payments are combined with interest paid abroad and divided by the weighted stock of net foreign liabilities, inclusive of equity investment.

Figure 2 shows that the total effective measure persistently exceeded the effective interest rate on foreign debt in nominal terms over the period, implying an 'equity premium' existed for foreign investors in Australia. This equity premium has widened significantly over recent years as the effective interest rate fell in line with global interest rates, thereby ensuring little variation in the nominal cost of foreign capital. 
Figure 2: Implicit Foreign Interest Rate and Cost of Foreign Capital, 1995-96 to 2004-05

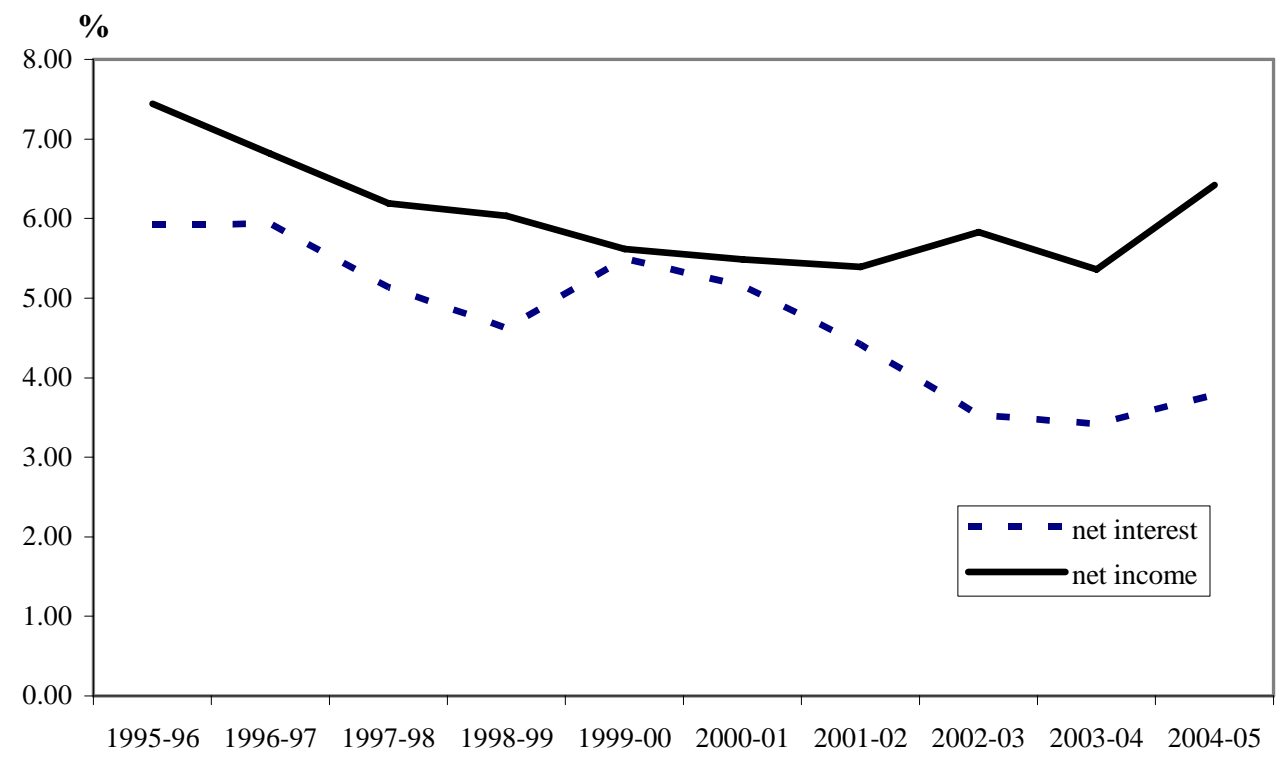

Notes:

$\mathrm{a}=$ based on data from Reserve Bank of Australia, Bulletin, Tables H5 and H7.

$\mathrm{b}=$ since the stock of debt changes through the year, the value of net external debt in the denominator should be a weighted average. The Australian Bureau of Statistics recommends a weights of two-thirds and one third respectively for beginning and of year values.

Table 2 presents estimates of the additional national income generated annually by foreign-financed capital that has accumulated over the past decade. In every year it is evident that the marginal product of foreign capital exceeded its servicing cost, the difference averaging over five per cent for the period.

This is not the full story however, because the earlier relation (13) underpinning this estimation exercise also implies that further national income gains or losses arise from period-to-period movements in the implicit interest rate as applied to the stock of foreign debt. In other words, the total servicing cost of foreign capital also rises or falls from year to year as the foreign interest rate varies. Foreign interest rate falls add to net income gains, whereas rises, inclusive of any increase in interest risk premiums charged by foreign lenders, subtracts from net income gains. 
Table 2: National Income Gains from Annual Foreign Capital Inflow

\begin{tabular}{l|cccccc}
\hline & $\begin{array}{c}\text { Net Foreign } \\
\text { Liabilities }(a)\end{array}$ & $\begin{array}{c}\text { Net Income } \\
\text { Payments } \\
\text { Abroad }(b)\end{array}$ & $\begin{array}{c}\text { Real Cost of } \\
\text { Foreign } \\
\text { Capital }(c)\end{array}$ & $\begin{array}{c}\text { Net Marginal } \\
\text { Product Less } \\
\text { Real Cost }(d)\end{array}$ & $\begin{array}{c}\text { Real CAB } \\
(e)\end{array}$ & $\begin{array}{c}\text { Real National } \\
\text { Income Gain } \\
(f)\end{array}$ \\
\hline Year & $(\$ b)$ & $(\$ b)$ & $(\%)$ & $(\%)$ & $(\$ b)$ & $(\$ b)$ \\
$1995-96$ & 262.0 & 19.5 & 4.0 & 4.5 & 24.7 & 1.1 \\
$1996-97$ & 280.2 & 19.1 & 5.4 & 2.8 & 19.6 & 0.5 \\
$1997-98$ & 292.4 & 18.1 & 4.7 & 4.0 & 25.2 & 1.0 \\
$1998-99$ & 305.1 & 18.4 & 4.4 & 4.2 & 36.5 & 1.5 \\
$1999-00$ & 324.0 & 18.2 & 3.2 & 5.6 & 35.2 & 2.0 \\
$2000-01$ & 340.9 & 18.7 & -0.4 & 9.1 & 18.7 & 1.7 \\
$2001-02$ & 365.5 & 19.7 & 2.3 & 6.6 & 21.4 & 1.4 \\
$2002-03$ & 386.0 & 22.5 & 3.8 & 5.1 & 42.0 & 2.1 \\
$2003-04$ & 442.1 & 23.7 & 4.2 & 5.0 & 47.8 & 2.4 \\
$2004-05$ & 485.8 & 31.2 & 4.6 & 4.5 & 56.1 & 2.5 \\
\hline
\end{tabular}

Notes:

$\mathrm{a}=$ weighted average measures of net foreign liabilities based on data in current prices from Reserve Bank of Australia, Bulletin, Table H5.

$\mathrm{b}=$ current price data from Reserve Bank of Australia, Bulletin, Table H7.

$\mathrm{c}=$ ex post real cost of foreign capital is the ratio of net income payments to net foreign liabilities less annual inflation rate; inflation data from Reserve Bank of Australia, Bulletin, Table G1.

$\mathrm{d}=$ the difference between the net marginal product of capital from Table 1 and the real cost of foreign capital.

e = external account imbalances from ABS (2005:18, Table1) expressed in 2003-04 prices after deflating by the Implicit Price Deflator for investment from ABS (2002:22, Table 8).

$\mathrm{f}=$ the product of the net marginal product of foreign capital less real servicing cost and the external imbalance in 2003-04 prices.

Year to year interest rate movements stem from changes in world interest rates, exchange rate swings affecting foreign currency denominated debt and any interest risk premium that may vary through time. Accordingly, Table 3 presents estimates of national income gains or losses arising from changes in the implicit foreign interest rate. World interest rates generally fell over the decade. Hence these interest-related income gains generally augment those shown in Table 2.

As the average age of capital is seventeen years, the new capital installed at the start of the decade in review could be expected to generate income throughout the entire period. For this reason the gains should also be considered cumulatively. On this basis, the extra real income stemming from foreign-funded 
capital over the decade was $\$ 23.3$ billion in constant prices, or $\$ 24.2$ billion in 2004-05 prices.

Table 3: Total National Income Gains from Foreign Capital

\begin{tabular}{c|cccccc}
\hline & $\begin{array}{c}\text { Change in } \\
\text { Implicit Foreign } \\
\text { Interest Rate }(a)\end{array}$ & $\begin{array}{c}\text { Income Gain } \\
\text { from Interest } \\
\text { Rate } \\
\text { Movements }(b)\end{array}$ & $\begin{array}{c}\text { Real Income } \\
\text { Gain from } \\
\text { Interest Rate } \\
\text { Movements }(c)\end{array}$ & $\begin{array}{c}\text { National Income } \\
\text { Gain from } \\
\text { Foreign Capital } \\
\text { (from Table 2) }\end{array}$ & $\begin{array}{c}\text { Total National } \\
\text { Income Gain } \\
(2003-04 \\
\text { prices) }(d)\end{array}$ & $\begin{array}{c}\text { Cumulative } \\
\text { Income Gain } \\
(2003-04 \\
\text { prices })\end{array}$ \\
\hline Year & $(\%)$ & $(\$ b)$ & $(\$ b)$ & $(\$ b)$ & $(\$ b)$ & $(\$ b)$ \\
$1995-96$ & 1.1 & 0.9 & 1.6 & 1.1 & 2.7 & 2.7 \\
$1996-97$ & 0.0 & 0.0 & 0.0 & 0.5 & 0.5 & 3.2 \\
$1997-98$ & 0.8 & 1.7 & 1.5 & 1.0 & 2.5 & 5.7 \\
$1998-99$ & 0.5 & 1.2 & 1.0 & 1.5 & 2.5 & 8.2 \\
$1999-00$ & -0.9 & -2.1 & -1.9 & 2.0 & 0.1 & 8.3 \\
$2000-01$ & 0.3 & 1.0 & 0.9 & 1.7 & 2.6 & 10.9 \\
$2001-02$ & 0.7 & 2.3 & 2.2 & 1.4 & 3.6 & 14.5 \\
$2002-03$ & 0.9 & 3.0 & 2.9 & 2.1 & 5.0 & 19.5 \\
$2003-04$ & 0.1 & 0.4 & 0.4 & 2.4 & 2.8 & 22.3 \\
$2004-05$ & -0.4 & -1.5 & -1.6 & 2.5 & 1.0 & 23.3 \\
\hline
\end{tabular}

Notes:

(a) the year to year change in the implicit foreign interest rate derived in Figure 4; data from Reserve Bank of Australia, Bulletin, Tables H5 and H7.

(b) the product of the weighted stock of net foreign debt and the change in the implicit foreign interest rate; data from Reserve Bank of Australia, Bulletin, Tables H5 and H7.

(c) the value of the income gain from interest rate changes deflated by the Implicit Price Deflator for Gross Domestic Product.

(d) the sum of the real national income gain from annual foreign capital inflow from Table 2 plus the real annual net gain from interest rate movements.

With a total workforce of around 9.8 million people in mid-2004-05, income per employed person in Australia was therefore approximately \$2,500 higher in 2004-05 prices than it would have been without the net capital inflow that occurred between 1995-96 and 2004-05. With a total population around 20.5 million at the time, national income per head was close to $\$ 1,100$ higher due to foreign capital inflow over the previous decade.

While these results attest to the benefits of capital inflow to Australia, they do not imply that foreign-funded investment generated no losses or bankruptcies at the firm level over the period. If unproductive capital results in widespread losses in any year, the value of the net marginal cost less foreign servicing cost would conceivably be much lower. Under such circumstances financial crisis and recession could result, especially if accompanied by rising interest rates. Such 
crises occasionally occur in emerging economies that borrow unsoundly at a premium (see Eichengreen, 2002; Glick, Moreno and Spiegel, 2001).

The macroeconomic methods and assumptions used above are of course subject to the standard criticisms that aggregative approaches attract. For instance, at the microeconomic level, saving and investment may be subject to various distortions that render them sub-optimal and domestic and foreign capital controls could affect the volume of capital inflows. Yet, the economy-wide impact of microeconomic distortions are difficult to assess and should significant ones exist, could have offsetting effects on the variables of most interest here. Microeconomic factors are therefore considered of second-order importance in this context.

It may be that other functional forms of macroeconomic production, such as the CES production function, better reflect the relationship between labour and capital in the Australian context (for instance with respect to the substitutability of labour and capital). Examining whether alternatives to the Cobb-Douglas specification of output generation used here could be adapted to reconfirm the above estimates of national income gains from foreign capital inflow to Australia is a worthy topic for future research. Whether dwelling investment should be treated in the same way as other forms of investment may also warrant further consideration in this context.

\section{Concluding Comments}

This paper has argued that persistent external deficits are symptomatic of a growth process in which the rate of capital accumulation exceeds the overall saving rate. By explicitly identifying the contribution of foreign capital to national income growth, it has shown that Australia's national income grew significantly faster due to the large current account deficits and higher debt levels of the past decade, yielding additional income on average of around $\$ 2,500$ per worker.

At the same time, there is a risk that future income gains could diminish if world interest rates keep rising or if a higher interest risk premium emerged. Indeed, the above estimates show that sometimes annual movements in the implicit foreign interest rate have been at least as significant as new foreign capital inflow as a source of variation in national income. Other things equal, an implicit interest rate in 2004-05 that was only 65 basis points higher would have been sufficient to offset the gain from capital inflow that year.

It may be argued that in the absence of capital inflow, domestic interest rates and hence domestic saving and domestic capital accumulation would have been higher. Yet there is little evidence of a strong relationship between interest rates and domestic consumption and saving in theory (standard textbook models for instance do not include interest rates in consumption functions) or empirically (see International Monetary Fund, 2005). Moreover, without capital inflow higher interest rates would have resulted in a smaller capital stock and hence national output. 
On balance, the annual income gains over the decade most likely understate the total contribution of foreign capital and should be considered minimum values. This is because part of capital inflow is direct foreign investment which entails the transfer of technology, work practices and management techniques that boost multifactor productivity. Hence, part of the multifactor productivity improvement over this time would be attributable to foreign capital rather than exclusively to domestic sources. Unfortunately, it is difficult to quantify exactly how much this would add to the foreign-contribution component of annual income growth.

Nonetheless, the straightforward method and benchmark estimates of the benefits of current account deficits and capital inflow over the past decade add a new dimension to the rekindled debate about the significance of Australia's external position.

\section{References}

Australian Bureau of Statistics (2005), Australian System of National Accounts, 2004-05, Cat 5204.0, Canberra.

Australian Bureau of Statistics (2002), 'Saving, Borrowing, Investment and Wealth', Special Article in Australian System of National Accounts, 2000-01, Cat 5204.0, Canberra.

Australian Bureau of Statistics (2005), Balance of Payments and International Investment Position, Australia, Cat 5302.0, Canberra.

Edwards, J. (2005), 'Uncomfortable Arithmetic', HSBC Australia and New Zealand Weekly, 6 June.

Eichengreen, B. (2002), Financial Crises and What to Do About Them, Oxford University Press, Oxford, UK.

Fischer, S. (2003), 'Financial Crises and Reform of the International Financial System' Weltwirtschaftliches Archiv, 139(1):1-37.

Frenkel, J., and A. Razin (1987), Fiscal Policies and the World Economy, MIT Press, Cambridge, Massachusetts.

Glick, R., R. Moreno and M. Spiegel, (2001) Financial Crises in Emerging Markets, Cambridge University Press, Cambridge, UK.

Grubel, H. (1987), 'Foreign Investment', pp. 403-6 in J. Eatwell, M. Milgate and P. Newman (eds), The New Palgrave Dictionary of Economics, vol. 2, Macmillan, London.

International Monetary Fund (2005 and earlier years) World Economic Outlook, IMF, Washington DC.

Lane, P. and G. Milesi-Ferretti (2002), 'Long-Term Capital Movements,' 73-116 in B. Bernanke and K. Rogoff (eds) NBER Macroeconomics Annual 2001, MIT Press, Cambridge, Massachusetts.

MacDougall, G. (1960), 'The Benefits and Costs of Private Investment from Abroad: A Theoretical Approach’, Economic Record March (Special Issue):13-35. 
Macfarlane, I. (2005) 'What are the Global Imbalamces?', Talk to Economic Society of Australia Dinner, Melbourne, 28 September, http://www.rba.gov.au/Speeches/2005/.

Makin, A. (2003), Global Finance and the Macroeconomy, Palgrave Macmillan, New York.

Makin, A. (1989), "Is the Current Account Deficit Sustainable?” Australian Economic Review (2nd quarter):29-33.

Mann, C. (2002), 'Perspectives on the US Current Account Deficit and Sustainability', Journal of Economic Perspectives 16(3):131-152.

Orr, A, M. Edey and M. Kennedy (1995), 'Real Long-term Interest Rates: The Evidence from Pooled-Time-Series’, OECD Economic Studies 25(2):76-107.

Reserve Bank of Australia, Bulletin, http://www.rba.gov.au/Statistics/

Ruffin, R. (1984), 'International Factor Movements’, pp. 237-88 in P. Kenen and R. Jones (eds), Handbook of International Economics vol. 1(Ch 5), North-Holland, Amsterdam.

Solow, R. (1956) 'A Contribution to the Theory of Economic Growth', Quarterly Journal of Economics 70:65-94.

Solow, R. (1957), 'Technical Change and the Aggregate Production Function', Review of Economics and Statistics 39(August):312-320.

Swan, W. (2005), ‘Australia’s Economic Challenges', Address to Australian Fabian Society National Policy Conference, Melbourne, 11 November, http://www.swanmp.org/.

The author is grateful to the Editor, Graeme Wells, and an anonymous referee for insightful and constructive comments. 



\section{Credit Markets and the Sons of Gwalia Judgement}

\section{Christine Brown and Kevin Davis}

$\mathrm{T}$

This paper examines the, potentially serious, consequences of a recent Federal Court of Australia decision for the cost of unsecured borrowing by Australian companies. The case in question is 'Sons of Gwalia Limited (Administrators Appointed) v Margaretic [2005] FCA 1305'. The decision of Justice Emmett (released on 15 September 2005), if not reversed on appeal, changes fundamentally the nature of shareholder's claims on the assets of an Australian company in the event of failure. In February 2006, the full bench of the Federal Court upheld the earlier decision (Buffini, 2006), and an appeal to the High Court by the liquidators and some creditors was heard on August 7-8 2006, with the judgment pending at the time of writing.

The effect of the Sons of Gwalia case is that shareholders purchasing shares shortly before a company is placed into administration may be able to claim compensation from the company's remaining assets and, in doing so, rank equally with unsecured creditors. These additional claims dilute the claims of unsecured creditors and would reduce the payout they receive relative to the amount owed.

Potential lenders to any Australian company are then, as a result of the Sons of Gwalia case, confronted with higher risk on unsecured debts (a lower recovery rate in the case of company failure) than before. Consequently we would expect interest rates charged on unsecured debt to increase to compensate for the increased risk. That is a question of interest to corporate debt markets, since corporate bonds are typically unsecured (and sometimes subordinated), and to other unsecured creditors such as trade creditors where such effects would show up as increases in the implicit interest rate involved in trade credit terms and conditions.

In this paper, we adapt modern techniques of credit risk modelling to estimate the magnitude of such an effect, and how sensitive it is to various economic characteristics of the companies involved. We find that the increased return which would be required by unsecured lenders is significant for many companies. We start with a section outlining the major features of the Sons of Gwalia case and explain why it leads to the outcome of some shareholders ranking equally with unsecured creditors in the event of failure (but not otherwise). We then explain how option pricing theory can be used to derive required credit spreads (the rates of return in excess of a risk free interest rate required by lenders) and adapted to this particular case. To estimate likely changes in credit spreads using such

Christine Brown is Associate Professor in the Department of Finance at The University of Melbourne and Kevin Davis is Commonwealth Bank Chair of Finance and Director of the Melbourne Centre for Financial Studies. 
models it is necessary to have some idea of the dilution effect on unsecured creditor payoffs arising from the elevation of shareholder claims. This is followed by a section which provides new data on the value of share turnover in periods prior to company failure and its size relative to unsecured debt outstanding for a sample of recently failed companies. This gives the inputs required to estimate the impact of Sons of Gwalia on credit spreads, and the estimates are presented in the next section. We conclude with some discussion of policy issues and other considerations for credit markets raised by the Sons of Gwalia judgment and provide some suggestions for further research.

\section{Sons of Gwalia Limited (Administrators Appointed) v Margaretic}

Justice Emmett's decision involved a finding in favour of a shareholder in Sons of Gwalia Ltd (an Australian company with stock market capitalisation of approximately $\$ 600$ million 6 months prior to insolvency) who claimed to be entitled to the status of a creditor of the company. The shareholder had purchased shares shortly before the company's failure during a period in which it is argued that the market was not fully informed about the company's financial position.

The class action case (funded by litigation funding group IMF Australia) relies on section 52 of the Trade Practices Act and gives rise to shareholders who are misled by a company having a right to compensation under consumer protection laws. Justice Emmett in handing down the decision said that the claim arose 'as a result of the consumer protection provisions ... which prohibit misleading and deceptive conduct'. The claim is in respect of 600 shareholders who will compete for a $\$ 400$ million pool of assets with creditors owed some $\$ 900$ million (Buffini, 2005). The decision drew on precedent established in English Law, and relates specifically to the interpretation of Section 563A of the Australian Corporations Act.

The rationale for the decision is outlined in Malleson Stephen Jacques (2005), which states that Section 563A implies that:

the claim of a shareholder against a company subject to winding up proceedings is postponed or subordinated to the claims of other creditors of the insolvent company, where the shareholder's claim is in that person's 'capacity as a member of the company'. However, subordination would not be required if the shareholder's claim against the company is not in that shareholder's 'capacity as a member'.

Mr Margetic's claim was based on the argument that Sons of Gwalia had engaged in misleading conduct (under the Trade Practices Act, the Corporations Act, and the Australian Securities and Investments Commission Act) by not meeting its continuous disclosure requirements. Because those Acts provide for payment of damages, he would, it was argued, be eligible for compensation for loss suffered from purchase of shares. This would not be in his capacity as a 
member of the company, and he should thus be eligible to rank equally with other (unsecured) creditors under Section 563A of the Australian Corporations Act.

The Sons of Gwalia judgment thus raises the spectre of fundamental changes in the status of claims of various stakeholders of an insolvent company. Specifically, some shareholders may be treated as having a claim equivalent to that of unsecured creditors. Those shareholders would be the ones who had purchased shares over some period prior to the company entering administration, if it could be shown that the company had not disclosed all relevant information to the market. The judgment is specific in limiting application to that category of shareholders, in situations of administration. Whether logic, rather than law, suggests similar implications for longer term shareholders, for those who subscribed for shares as part of a capital raising, or even for shareholders of a solvent company where non-disclosure was proved, are matters we postpone for later discussion.

It is tempting to focus upon the implications of this judgment for the consequences arising when failure has occurred. The administration process may become more costly and drawn out, as the validity of shareholder claims must be determined in the courts. The recovery rates of unsecured creditors would be diluted by the expansion of their ranks to include some subset of shareholders.

Indeed, the uncertainty surrounding the eventual outcome of appeals against the decision has already impacted upon the administration process for other Australian companies which have recently entered financial distress. In the case of ION Limited, which was suspended from trading in December 2004, with unsecured debts in the order of \$369 million (as reported in the Balance Sheet for June 2004), the administrators have delayed distributions to creditors because of the uncertainty over whether claims by shareholders will rank equivalently. At November 2005, the administrators advised that 'some 2,500 proofs [from shareholders] have been received totalling approximately $\$ 113 \mathrm{~m}$ '. (McGrathNicol+Partners, 2005).

But potentially more interesting, and more complex, are the general effects which would be observed in credit markets. Lenders to any company, in setting credit terms, take into account the possibility that the company may default and that they will not fully recover the amount owed. The lower recovery rates implied under the Sons of Gwalia judgment would mean that credit spreads would increase. In the following section we explain how modern techniques of credit risk modelling can be adapted to estimate the size of this effect.

\section{Option Pricing Framework}

Under the Sons of Gwalia decision, the court gives a group of shareholders the right to act as unsecured creditors of a company which has become insolvent. This does not affect the probability of insolvency occurring, but reduces the recovery rate of other unsecured creditors should insolvency occur. Consequently, the rate of return demanded by unsecured creditors should increase to compensate for this increase in risk. In practice, many unsecured creditors are trade creditors, 
and thus the credit spread effects we examine show up as changes in trade credit terms and conditions. In this section we develop a framework to assess how the Sons of Gwalia decision affects the value of an unsecured creditor's claim on the assets of a company, and thus the likely impact on the rate of return which would be demanded by an unsecured creditor.

\section{Unsecured debt only}

Assume first that the company has only unsecured debt on issue. Figure 1 provides a simple depiction of how the assets of the company are divided between shareholders and creditors at the debt maturity date $(T) . \quad V_{T}$ is the value of the firm's assets at $\mathrm{T}$ and $\mathrm{F}$ is the promised repayment amount of the debt ${ }^{1}$. If the firm's assets exceed the amount owed to creditors $\left(V_{T}>F\right)$, the firm is solvent, creditors are paid the promised amount, the value of shareholder equity is $\left(\mathrm{V}_{\mathrm{T}}\right.$ $\mathrm{F})>0$ and the firm survives into the future. If the promises to creditors cannot be met $\left(\mathrm{V}_{\mathrm{T}}<\mathrm{F}\right)$, the firm is placed in administration with creditors receiving all of the available assets. Hence the (dashed) payoff line for equity holders is zero up to the point $\mathrm{F}$ on the diagram, and the payoff to bondholders is given by the solid line

\section{Figure 1: Traditional Modelling of Debt and Equity Payoffs}

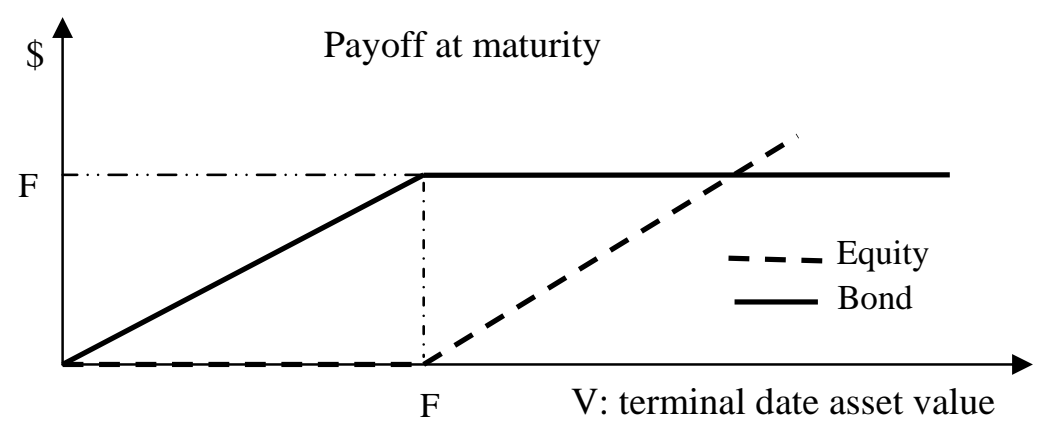

As Merton (1974) noted, this payoff structure for holders of risky debt can be shown to be equivalent to holding a risk-free debt and having granted an option to the shareholders to put (that is, transfer the ownership of) the firm's assets to the bondholders, in the event of the firm defaulting, in settlement of the debt. Hence holding risky debt can be modelled as being equivalent to holding riskless debt plus being short (that is, having written or sold) a put option on the firm's assets. Shareholders 'own' the put option on the assets of the firm because they have

\footnotetext{
${ }^{1}$ The modelling assumes that the debt is of the zero-coupon variety, such that no payment is due until the maturity date. In practice, such debt is uncommon, as is the assumption that all unsecured debt outstanding matures at the same date. However, it is possible to approximate many of the characteristics of a portfolio of coupon bearing debts with different maturities by a single zero-coupon security.
} 
limited liability and can 'walk away' from the obligation (of $\mathrm{F}$ ) to creditors by forfeiting the firm's remaining assets $\left(\mathrm{V}_{\mathrm{T}}\right)$ to them.

The benefit of adopting this perspective is that finance theory offers a method to derive the value of, and the required yield on, the risky debt at its issue date (or any time prior to its maturity) by drawing upon option pricing theory. Prior to the maturity date, the price of the put option can be calculated using the option pricing model developed by Black and Scholes (1973). Merton (1974) demonstrated how the credit spread can then be simply derived.

Merton's approach involved noting that a risk free discount bond promising $\mathrm{F}$ at time $\mathrm{T}$ with a risk free yield of $\mathrm{r}$ per cent, would have a higher current market value than the risky bond promising the same amount. The difference is the value of the put option over the firm's assets (V) for a strike price of F. Since the value of the risk free bond and the put option can both be calculated using finance theory, the implied market value of the risky bond (B) can then be derived. The required yield on the risky bond $(\mathrm{y})$ is derived as the discount rate which equates the present value of the promised payoff $\mathrm{F}$ at time $\mathrm{T}$ to the derived market value $\mathrm{B}$. The credit spread is then given by $\mathrm{c}=\mathrm{y}-\mathrm{r}$. For any specified maturity, the credit spread turns out to be a function of only two variables: the variance (or volatility) of the firm's assets and the leverage of the firm. The higher is leverage measured here as the ratio of the promised debt payment (discounted at the risk free rate) to the current value of the firm - the higher is the credit spread. The higher is asset volatility, the higher the credit spread. ${ }^{2}$

Assume now that a group of the shareholders is deemed to rank equally with unsecured creditors in the event of insolvency. Unsecured creditors are owed F, and let the shareholder group's claim on the company's assets be equal to X. If the firm value is greater than $F$, the unsecured creditors receive the full value of their claim. When the firm value $\mathrm{V}_{\mathrm{T}}$ is below $\mathrm{F}$, the firm is in default (insolvency occurs) and the unsecured creditors' claim is now diluted to $F /(F+X)$ of the available assets. Note that even though the claims when insolvency occurs are $(\mathrm{F}+\mathrm{X})$, insolvency is not triggered until firm assets fall below the debt holder claims of $\mathrm{F}$. The payoff for unsecured creditors when shareholders have a claim to $\mathrm{X} /(\mathrm{F}+\mathrm{X})$ of the remaining assets in insolvency is illustrated in Figure 2.

The graphical depiction of the claims of the various stakeholders (as in Figures 1 and 2) provides insight into how the payoff can be constructed from a combination of fundamental instruments. In Figure 1 the fundamental instruments were a riskless bond and a put option on the firm's assets. In Figure 2 the payoff can be modelled as equivalent to a long (bought) position in a riskless bond of face value $[\mathrm{F} /(\mathrm{F}+\mathrm{X})] \mathrm{F}$, plus a short (sold) position in $[\mathrm{F} /(\mathrm{F}+\mathrm{X})]$ put options with strike price $F$, plus a long position in a digital option that pays $[\mathrm{X} /(\mathrm{F}+\mathrm{X})] \mathrm{F}$ when $\mathrm{V}_{\mathrm{T}}>\mathrm{F}$ and zero otherwise. Table 1 illustrates how the payoffs from this combination of financial instruments leads to a payoff of $F$ when the firm is solvent $\left(V_{T}>F\right)$ and a payoff of $[\mathrm{F} /(\mathrm{F}+\mathrm{X})] \mathrm{V}_{\mathrm{T}}$ when the firm is insolvent $\left(\mathrm{V}_{\mathrm{T}}<\mathrm{F}\right)$. The first two

\footnotetext{
${ }^{2}$ Explicit formulae for the pricing and credit spread equations are available on request from the authors.
} 
components are equivalent to a proportion $[\mathrm{F} /(\mathrm{F}+\mathrm{X})]$ of a risky bond with face value F. Each of these components can be valued using option pricing theory and the overall value of the security whose payoff is given in Figure 2 is obtained by summing the value of the components. The credit spread for unsecured debt in this case $\left(\mathrm{c}^{*}\right)$ can be calculated similarly to before, and the impact of the change implied by the Sons of Gwalia judgment measured by the difference in the credit spreads, or $\left(\mathrm{c}^{*}-\mathrm{c}\right)$.

Figure 2: Debt Payoff When Dilution by Equal Status of Some Shareholder Claims Occurs

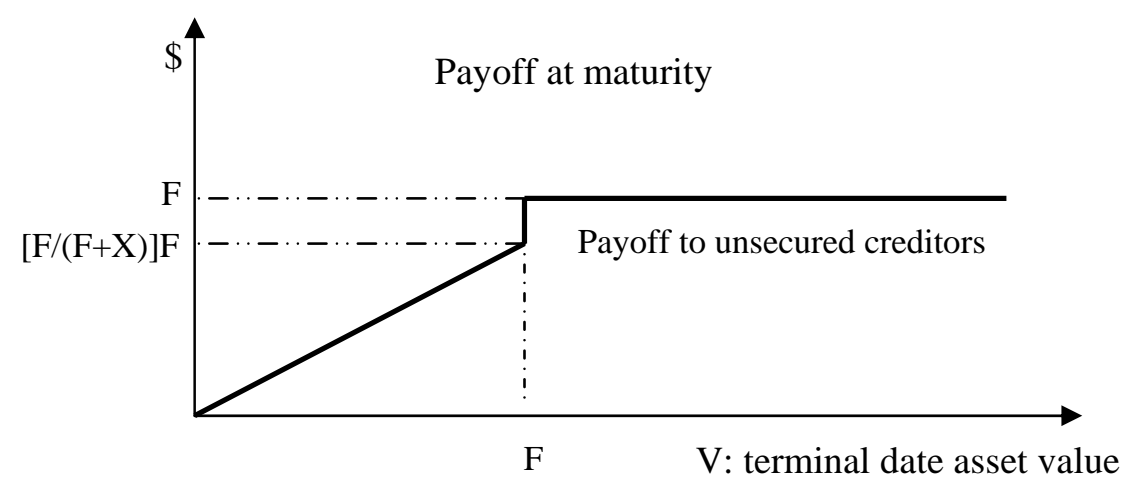

Table 1: Payoffs of Replicating Portfolio for Risky Debt When Dilution Occurs

\begin{tabular}{lcc}
\hline & \multicolumn{2}{c}{ Payoffs } \\
\hline & $\begin{array}{c}\mathrm{V}_{\mathrm{T}}<\mathrm{F} \\
\text { Insolvency }\end{array}$ & $\begin{array}{c}\mathrm{V}_{\mathrm{T}}>\mathrm{F} \\
\text { Solvency }\end{array}$ \\
\cline { 2 - 3 } Long riskless bond promising $\frac{F}{X+F} F$ & $\frac{F}{X+F} F$ & $\frac{F}{X+F} F$ \\
Short $\frac{F}{X+F}$ puts at strike of $F$ & $-\frac{F}{X+F}\left(F-V_{T}\right)$ & 0 \\
Long digital option paying $\frac{F}{X+F} F$ & $\frac{F}{X+F} F$ \\
\cline { 2 - 3 } & $\frac{F}{X+F} V_{T}$ & $F$ \\
\hline
\end{tabular}




\section{Secured and unsecured debt}

Assume now that the firm has both secured debt with face value $F_{S}$ and unsecured debt with face value $\mathrm{F}_{\mathrm{U}}$. When the firm is solvent at maturity of the debt $\left(\mathrm{V}_{\mathrm{T}}>\mathrm{F}_{\mathrm{S}}+\mathrm{F}_{\mathrm{U}}\right)$ the unsecured (secured) creditors are paid the promised amount $\mathrm{F}_{\mathrm{U}}$ $\left(F_{S}\right)$. When the promises to all creditors cannot be met $\left(V_{T}<F_{S}+F_{U}\right)$ but $V_{T}>F_{S}$ then secured creditors will be paid in full and unsecured creditors receive any excess of firm value over $\mathrm{F}_{\mathrm{S}}$. In the event that $\mathrm{V}_{\mathrm{T}}<\mathrm{F}_{\mathrm{S}}$, unsecured creditors receive nothing. This payoff to unsecured creditors in the absence of dilution by shareholder claims is given in Figure 3. The payoff can be shown to be equivalent to the payoff on a long (bought) call option with strike price $\mathrm{F}_{\mathrm{S}}$ and a short (sold) call option with strike price $\mathrm{F}_{\mathrm{S}}+\mathrm{F}_{\mathrm{U}}$. These options can be priced using the Black and Scholes (1973) formula and the credit spread calculated using the method outlined earlier.

\section{Figure 3: Traditional Payoff to Unsecured Creditors when Secured Debt Exists}

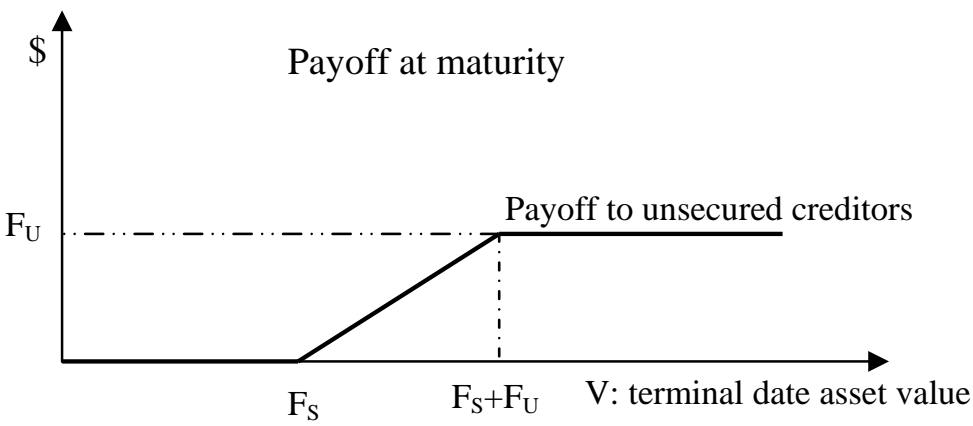

\section{Figure 4: Unsecured Debt Payoff when Secured Debt Exists and Dilution by Shareholder Claims Occurs}

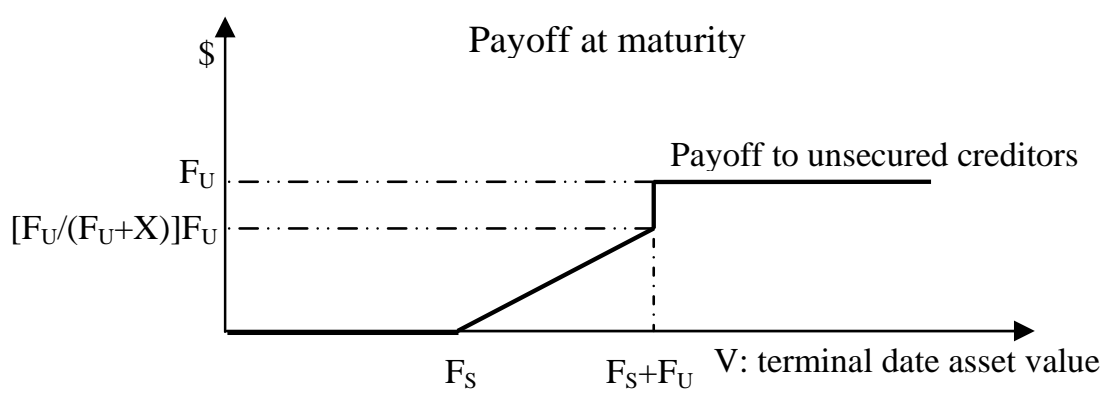


When a group of shareholders with claim $\mathrm{X}$ is ranked equally with the unsecured creditors in the event of insolvency, the payoff to the unsecured creditors is illustrated in Figure 4. The approach to constructing Figure 4 from Figure 3 is identical to that used to construct Figure 2 from Figure 1. In this case when the promises to creditors cannot be met $\left(\mathrm{V}_{\mathrm{T}}<\mathrm{F}_{\mathrm{S}}+\mathrm{F}_{\mathrm{U}}\right)$, but $\mathrm{V}_{\mathrm{T}}>\mathrm{F}_{\mathrm{S}}$, then secured creditors will be paid in full and unsecured creditors' claim is now diluted to $\mathrm{F}_{\mathrm{U}} /\left(\mathrm{F}_{\mathrm{U}}+\mathrm{X}\right)$ of the available assets. It can be shown that this payoff is equivalent to $\left[\mathrm{F}_{\mathrm{U}} /\left(\mathrm{F}_{\mathrm{U}}+\mathrm{X}\right)\right]$ times the payoff on unsecured debt when all shareholders rank after unsecured creditors (as illustrated in Figure 3) plus a digital option which pays $\left[\mathrm{X} /\left(\mathrm{F}_{\mathrm{U}}+\mathrm{X}\right)\right] \mathrm{F}_{\mathrm{U}}$ when $\mathrm{V}>\mathrm{F}_{\mathrm{S}}+\mathrm{F}_{\mathrm{U}}$ and 0 otherwise.

Consequently, the bond price and credit spread can be calculated using option pricing theory and, as in the previous section, the change in credit spread resulting from the change in status of shareholder claims can be calculated.

\section{Potential Size of Shareholder Claims}

The Sons of Gwalia judgement was the result of a class action mounted by a specialist litigation funding company on behalf of a group of shareholders. How many shareholders would, in general, rank as unsecured claimants, and the value of their claims relative to that of unsecured creditors, is (in the absence of precedent) unknown. Since the judgement is based on shareholders purchasing shares under a situation of misinformation, it is likely that implementation of such a ruling would be limited to those investors who became new shareholders in some limited number of months prior to the insolvency occurring.

To gain some understanding of likely magnitudes involved, we have collected data on the share turnover of failed companies in the period prior to insolvency. For the calendar years 2003, 2004 and 2005 we have identified (using www.delisted.com.au) 52 listed companies which were delisted from the ASX as a result of insolvency.

The path to insolvency can be complex, sometimes involving prior announcements or market rumours of trading difficulties. Consequently, in some cases it is unlikely that purchasers of shares in some short period prior to delisting would be able to sustain a case for compensation as claimants on the company. For this reason, companies which did not appear to have traded, or had a history of very thin trading or were 'penny dreadful' stocks with a share price of a few cents were removed from the sample (the list of companies retained in the sample is available from the authors on request). This left 30 stocks for which data on trading volume and value for a period prior to delisting were available.

We use the date of suspension from trading associated with, or prior to, the announcement of an administrator as the basis for calculating share purchase volumes and values in the period prior to an insolvency. We have calculated both the value and volume of shares purchased for a range of periods prior to suspension, and report results for the 30 and 90 day periods. The volume of shares is expressed as a percentage of the stock on issue. Note that these figures are an 
upper bound for the number of recent purchasers holding the stock at the suspension date, since some purchasers may have resold the stock before the suspension. The severity of this problem increases with the length of period considered and also with the turnover rate for the stock.

We have also collected data on the value of unsecured creditors (measured as total liabilities minus secured creditors) of companies in our sample as at the last available balance sheet date prior to suspension. In some cases this may be as much as 18 months prior to suspension (since subsequent annual reports may not have been filed). To our knowledge, the question of whether, on average, unsecured debts increase or decrease in the months prior to insolvency has not been fully resolved, and hence we take this figure as indicative of the size of unsecured debt outstanding at the time of suspension.

Figure 5 provides a perspective on the turnover of shares 30 days prior to suspension. It is clear that in many cases significant purchases of shares are made in a short period prior to failure, creating the possibility of substantial shareholder claims for compensation. There is no apparent relationship between size of the company (measured by market capitalisation 180 days prior to suspension) and the turnover of shares in the period leading up to insolvency. Turnover for Sons of Gwalia, at 21 per cent of stock outstanding, was the fifth highest in our sample.

\section{Figure 5: Stock Turnover Prior to Share Market Suspension}

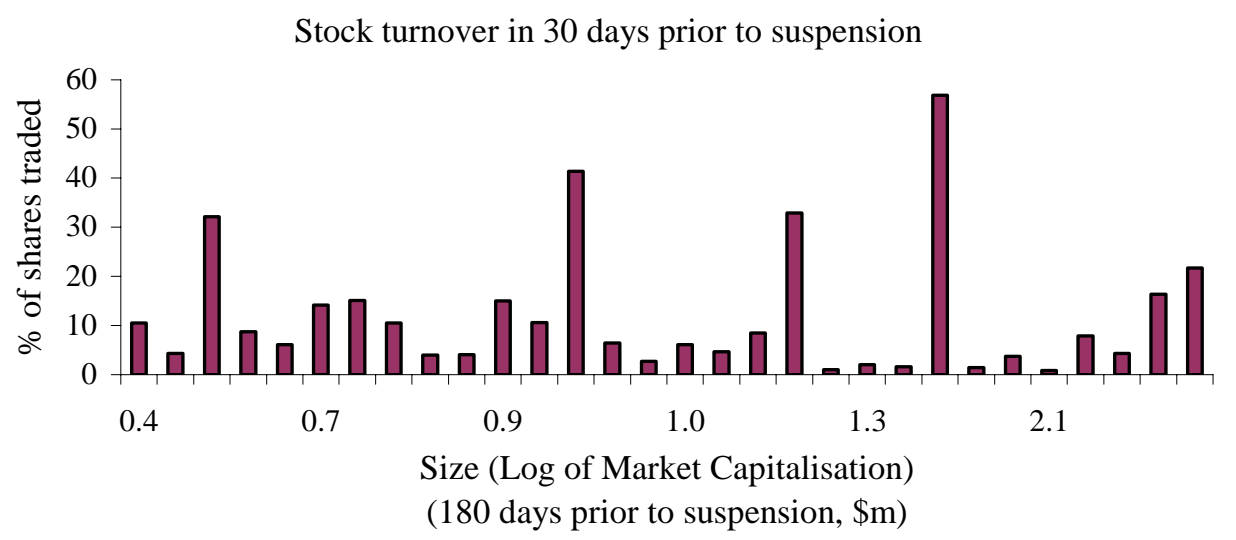

The value of shares traded in a given period prior to insolvency relative to the amount owed to unsecured creditors varies markedly, reflecting both the volume of trading and the leverage of the company. Table 2 provides summary information on the dilution effect (corresponding to $\mathrm{X} / \mathrm{F}$ in our earlier notation) by deciles based on a leverage measure. These dilution estimates are an upper bound since they do not allow for cases where recent purchasers have resold those shares prior to the company's failure. In Table 2, leverage is measured as unsecured debt (reported in the last annual report available prior to suspension) as a ratio to the company's market capitalisation 180 days prior to suspension (corresponding 
approximately to $\mathrm{F} /(\mathrm{V}-\mathrm{F})$ using our earlier notation). For companies with low leverage, the potential dilution effect is naturally very high. For companies with high leverage, the dilution effect is much less, even when there has been substantial stock turnover.

Table 2: Potential Equity Claimants Relative to Unsecured Creditors

\begin{tabular}{ccc}
\hline $\begin{array}{c}\text { Quintiles } \\
\text { (based on leverage) }\end{array}$ & $\begin{array}{c}\text { Leverage: } \\
\text { Unsecured Debt/Equity } \\
\text { Ratio (Average) }\end{array}$ & $\begin{array}{c}\text { Dilution: } \\
\text { Share Value Traded in 90 } \\
\text { days prior to suspension } \\
\text { as a ratio to Unsecured } \\
\text { Debt }\end{array}$ \\
\hline 1 (lowest leverage) & $9 \%$ & $309 \%$ \\
2 & $31 \%$ & $74 \%$ \\
3 & $66 \%$ & $18 \%$ \\
4 & $111 \%$ & $25 \%$ \\
5 (highest leverage) & $513 \%$ & $16 \%$ \\
\hline
\end{tabular}

Table 2 illustrates that there is clearly great diversity in the possible dilution effects on unsecured creditors arising from the Sons of Gwalia decision.

The data in Table 2 are ex post, but for the determination of credit spreads we require an estimate of the expected or average dilution effect as at some date prior to company failure. Consequently Table 3 provides some estimates of the average dilution effect, using different weighting methods. Based on our sample of failed companies, if all purchasers of shares in the thirty days prior to failure were eligible to rank equally with unsecured creditors as claimants, the dilution effect would be 37 per cent, using an unweighted average. Weighting the data by leverage, the dilution effect falls to six per cent.

Table 3: Ratio of Potential Equity Claimants/Unsecured Creditors

\begin{tabular}{lcc}
\hline & \multicolumn{2}{c}{ Eligibility Period } \\
& 30 days & 90 days \\
\hline Unweighted Average & $37 \%$ & $88 \%$ \\
Weighted Averages Using: & & \\
$\quad$ Market Capitalisation & $16 \%$ & $41 \%$ \\
$\quad$ Leverage (Unsecured Debt/Market Capitalisation) & $6 \%$ & $24 \%$ \\
\hline
\end{tabular}




\section{Likely Size of Sons of Gwalia Credit Spread Effect.}

Our objective is to provide a 'ball-park' estimate of the likely changes in credit spreads on unsecured debt resulting from the Sons of Gwalia judgment. The information obtained from our study of recent company failures and described in the previous section provides us with some idea of reasonable input parameter values required to make such a calculation. The critical parameters, as outlined earlier are the dilution effect and volatility of the company's assets.

The dilution effect arises from a group of shareholders with claim $\mathrm{X}$ being ranked equally with unsecured creditors with claim $\mathrm{F}_{\mathrm{U}}$ on the company's assets. Based on the data in Table 3, we choose dilution effects represented by a ratio of 0.4 for $\mathrm{X} / \mathrm{F}_{\mathrm{U}}$ as being realistic. In doing so, we note that the experience of ION referred to earlier involves claims lodged by shareholders of approximately $\$ 113 \mathrm{~m}$, which is equivalent to the value of shares purchased in the 60 days prior to delisting. In Table 4 we show results from calculating the increase in credit spread assuming that the company has both secured and unsecured debt on issue. We assume a volatility of asset value of 30 per cent because, as shown by Duan et al (2004), this has been shown to calibrate the Merton model estimates of credit spreads to actual data. We choose a maturity of 5 years since this is a common initial maturity for corporate unsecured bond issues.

Table 4: Increase in Credit Spread on Unsecured Debt: Secured and Unsecured Debt Outstanding.

\begin{tabular}{|c|c|c|c|c|c|c|c|}
\hline $\begin{array}{l}\text { Unsecured } \\
\text { Debt/Assets }\end{array}$ & \multicolumn{7}{|c|}{$\begin{array}{l}\text { increase in credit spread } \\
\text { (basis points) }\end{array}$} \\
\hline 0.8 & & & & & & & 161.0 \\
\hline 0.7 & & & & & & 127.5 & 152.3 \\
\hline 0.6 & & & & & 94.4 & 119.8 & 140.6 \\
\hline 0.5 & & & & 63.2 & 87.9 & 108.9 & 125.0 \\
\hline 0.4 & & & 35.9 & 58.1 & 78.1 & 94.0 & 105.8 \\
\hline 0.3 & & 15.2 & 32.4 & 49.8 & 64.3 & 75.3 & 83.2 \\
\hline \multirow[t]{3}{*}{0.2} & 3.5 & 13.2 & 25.9 & 37.3 & 46.4 & 53.0 & 57.8 \\
\hline & 0.2 & 0.3 & 0.4 & 0.5 & 0.6 & 0.7 & 0.8 \\
\hline & \multicolumn{7}{|c|}{ Total Debt/Assets } \\
\hline
\end{tabular}

Notes: Debt to assets ratios are measured using the face value of debt and the market value of assets.

Volatility $=30 \%$ p.a., Maturity $=5$ years, risk free interest rate $=5 \%$, Dilution effect (shareholder proportion): $\mathrm{X} / \mathrm{F}_{\mathrm{U}}=0.4$.

Along the horizontal axis of Table 4 is the total debt to assets ratio and along the vertical asset is the unsecured debt to asset ratio. Thus, when the total debt to asset ratio is 0.8 and the unsecured debt to asset ratio is also 0.8 , the company has only unsecured debt outstanding. For example for a company with only unsecured debt outstanding and a ratio of unsecured debt to assets of 0.7 , the increase in 
credit spread is 127.5 basis points on an initial spread of 183 basis points. When the total debt to assets ratio is 0.7 and the unsecured debt to assets ratio is 0.4 , then unsecured debt forms $4 / 7$ of the total debt and the increase in spread is 94 basis points. As would be expected, holding the total debt to assets ratio constant, the increase in credit spread is increasing in the proportion of the debt that is unsecured. If the same results were reproduced for a lower value of $\mathrm{X} / \mathrm{F}_{\mathrm{U}}$ the patterns remain the same, but the corresponding increases in the credit spreads are lower. For example if $\mathrm{X} / \mathrm{F}_{\mathrm{U}}=0.2$ for a company with unsecured debt only, the increase in credit spread is 73.4 basis points when the unsecured debt to assets ratio is 0.7 . This compares with a 127.5 basis point increase when $\mathrm{X} / \mathrm{F}_{\mathrm{U}}=0.4$.

It would be possible to make a range of estimates of the potential increases in credit spreads arising from implementation of the Sons of Gwalia decision for companies with different characteristics in addition to the differences in leverage examined in Table 4. Different volatility figures and time to maturity for unsecured debt could be assumed. Different dilution factors could also be applied.

However, the basic message of the results presented above is clear: the credit spread on unsecured debt for Australian companies could increase substantially. This would be particularly so for companies heavily reliant on unsecured debt, those with volatile share prices, and those with a relatively high share turnover.

\section{Conclusion}

Notwithstanding the appeal to the High Court, the Sons of Gwalia decision implies that a shareholder would have an admissible claim against a company if the shares were bought on-market where a breach of contract such as misrepresentation by the company can be proven. Trading while insolvent would clearly fall into that category (and leave directors open to legal charges) but so also would appear to be situations in which full disclosure to the market of company performance had not occurred. Despite continuous disclosure requirements imposed by the Australian Stock Exchange, it is to be expected that companies entering financial distress are reluctant to publicise every piece of adverse information which may further hasten their decline. Consequently, there is likely to be some serious questioning of what constitutes information which should be provided to the market by Boards of Directors and Management. This may serve to focus discussion on the distinction between 'inside' (informed) and 'outside' (uninformed) equity stakeholders and the implications for legal rights of the latter group beyond their status in insolvency as addressed by the Sons of Gwalia judgment.

There are some more general questions raised by the judgment. First, why do recent purchasers of shares have a claim because of inadequate disclosure, when longer term shareholders, who may have sold if such information was disclosed, do not? ${ }^{3}$ One answer, although legal considerations may provide others, is that

\footnotetext{
${ }^{3}$ It should also be noted that the courts have previously rejected a claim to participate in the division of assets in liquidation by shareholders who subscribed to a capital raising of a company which subsequently failed. (Malleson, Stephen Jacques, 2005).
} 
such shareholders were owners of the company when the events causing its loss in value occurred, and disclosure would have reduced the share price causing them to suffer a loss on the sale of shares anyway. A further consideration is whether purchasers of shares would be able to claim against a solvent company for loss due to non-disclosure. This would appear possible under provisions of the various Acts referred to earlier dealing with misleading information, but proving such a case is likely to be substantially more problematic than the situation dealt with in the Sons of Gwalia case, where company failure occurs.

In this paper our focus has been exclusively on the implications of the judgment for corporate debt markets and specifically upon its consequences for corporate credit spreads (the cost of debt finance). It is apparent, however, that equity market values may also be affected. To the extent that shareholders gain at the expense of creditors when liquidation occurs, the judgment could be viewed as good news for shareholders of all companies, with consequent beneficial effects upon share prices. However, any such effect would be offset if credit spreads rise as argued above. Moreover, the general uncertainty of treatment of stakeholder claims engendered by the decision (and likelihood of further challenges) may have adverse effects upon the share prices of Australian companies.

These comments indicate a potentially valuable line for future research. Provided that market participants believed that there was some probability of the Sons of Gwalia decision surviving subsequent legal challenges, the announcement of the decision (and result of subsequent challenge) should have led to some increase in credit spreads in corporate debt markets. Examining whether that did, in fact occur, and how equity markets responded, to assess the extent which value was transferred between stakeholders and the extent of any more general uncertainty effects, is worthy of further study.

We have argued that the resulting ambiguity with regard to the traditionally accepted investor hierarchy of claims in the event of corporate collapse has the potential to affect credit spreads in the market for corporate debt. Using an option pricing framework and assuming a proportion of shareholders are reclassified as unsecured creditors we have provided some estimates of the potential increase in credit spreads to demonstrate that this is a matter of economic significance. Banks as lenders, trade creditors, and institutional investors as buyers of corporate bonds are all potentially affected, and the ability of Australian companies to issue debt into international markets (in competition for funds with overseas companies where creditor rights are not subject to such dilution effects) are adversely affected.

Of course, the Sons of Gwalia decision may not survive the legal and political processes, making it a temporary hiccup in Australian corporate finance. A US funds management arm of the Dutch banking and insurance group ING, which bought bonds issued by Sons of Gwalia, claimed that Justice Arthur Emmett 'erred in law' in his original decision and should have ruled that a shareholder's claim be 'postponed until all debts owed to (creditors) have been satisfied' (Catalano, 2005). ING's Australian solicitor has stated that the whole unsecured creditor 
base of Sons of Gwalia is owed $\$ 862 \mathrm{~m}$ and that ING had decided to appeal to the High Court (Sexton, 2006).

It is likely that if the High Court upholds the Federal Court decision then lenders will lobby to have the Corporations Act changed, so that shareholders are always ranked behind creditors. It seems likely that political and economic expediency would lead to such a change. However, the Sons of Gwalia decision has opened a significant can of worms by recognizing that legal precedent implies that 'outsiders' who buy shares on-market are, in some way, akin to underinformed consumers entitled to some degree of protection at the expense of other stakeholders in the company. Changing the Corporations Act as suggested above would remove one possible form of such protection, but do nothing to address the underlying problem.

\section{References}

Black, F. and M. Scholes (1973), 'The Pricing of Options and Corporate Liabilities', Journal of Political Economy 81:637-659.

Buffini, F. (2005), 'Shareholder Wins Right to be a Creditor', Australian Financial Review 16 September:3.

Buffini, F. (2006), 'Gwalia Investor's Equality with Creditors Upheld', Australian Financial Review 28 February:9.

Catalano, C. (2005), 'Scraps for Pieces of Gwalia', The Age 10 October:3.

Duan, J., J. Simonato, G. Gauthier and S. Zaanoun (2004), 'Estimating Merton's Model by Maximum Likelihood with Survivorship Consideration' (March). EFA 2004 Maastricht Meetings Paper No. 4190. Available at SSRN: http://ssrn.com/abstract=557088.

McGrathNicol+Partners (2005), 'Deed Administrators' Update 28 November 2005', http://www.ionlimited.com.au/images/articles/051202.pdf.

Mallesons Stephen Jaques (2005), 'Sons of Gwalia Limited: Members as Creditors: Sons of Gwalia Limited (Administrators Appointed) v Margaretic [2005] FCA 1305', http://www.mallesons.com/publications/alerts/2005/8124607w.htm.

Merton, R. (1974), 'On the Pricing of Corporate Debt: The Risk Structure of Interest Rates’, Journal of Finance 29: 449-470.

Sexton, E. (2006), 'Riff-raff Slip into the Creditors' Queue', The Sydney Morning Herald 20 March:19.

We are grateful to the referees, Tim Brailsford and Richard Heaney and the editor for helpful comments. 


\section{ACT Financial Management: Victim or Villain?}

\section{Chris Uhlmann}

I $n$ the months following the release of the 2006-07 Australian Capital Territory (ACT) Government budget there was a recurring theme in the reaction: people were shocked by the extent of the cuts to services and the steep increases in taxes. They should not have been. Since late 2005 the Stanhope Labor Government had been hinting at significant change and it had initiated a review of the territory bureaucracy and all its services. In his budget speech, Chief Minister and Treasurer Jon Stanhope made no apology for the pain his budget would cause, saying he was tackling issues left untended since the territory achieved selfgovernment in 1989. The territory had been living beyond its means for too long, he said, enjoying services that were on average 20 per cent more expensive than the Australian standard. Successive territory government's had been 'complicit in this history' and his would be the first with the courage to address the problem (ACT Budget Speech, 2006:1-2).

There was truth in what Stanhope said. The territory's expensive set of services is an overhang from the days when it was run by the Commonwealth and structural change is overdue. However, this alone does not explain the Stanhope Government's dramatic fiscal tightening halfway through its second term. This paper contends that the immediate cause of the large budget deficit, which drove the drastic correction, was mismanagement. It also contends that the Government was slow to realise the depth of the problem because its ministers did not understand flaws in the budget's accounting system, which served to disguise the magnitude of the financial problem by including a menu of items that turned an underlying deficit into a headline surplus. That system was abandoned in this year's budget and the territory adopted something approaching the accepted national standard.

\section{The Deficit}

Between June 2002 and June 2004, the Stanhope Government turned a modest surplus of $\$ 12 \mathrm{~m}$ into a deficit of $\$ 291 \mathrm{~m}$, when measured in national accounting terms (Australian Bureau of Statistics - ABS, 2006a). By the same measure, the Government (ACT Treasury, 2006a and ACT Budget, 2006-07) forecasts deficits of $\$ 123 \mathrm{~m}$ when the books finally close on the 2005/06 financial year and $\$ 147 \mathrm{~m}$ at the end of 2006/07. (These figures are drawn from the nationally accepted standard, Government Finance Statistics (GFS). Until this year the ACT Government used a different accounting standard, which will be discussed later.

Chris Uhlmann is a Canberra-based freelance writer and media consultant. 
From 2006/07 it is using its own variation of GFS, which includes as revenue expected-long term capital gains on superannuation investments. By that standard, the deficit for $2005 / 06$ is $\$ 91 \mathrm{~m}$ and a deficit of $\$ 80 \mathrm{~m}$ is projected for 2006/07.)

Listen to the Government and its predicament is entirely due to structural problems that have haunted the territory since it achieved self-government in 1989. Others put it down to the Stanhope Government's financial ineptitude. There is truth on both sides, although it is hard to attribute the recent, spectacular decline to anything other than negligence.

\section{The Good Times}

Labor won government in October 2001. It was re-elected in 2004 and, for the first time in the short history of self-government in the ACT, Stanhope won a majority in the 17-seat Legislative Assembly. That was not his only piece of good fortune, for he was governing at a time of remarkable economic prosperity.

The Economist (2005) has described the international rise in house prices from the late 90s on as the 'biggest bubble in history', dwarfing 'any previous house-price boom, larger than the global stock market bubble in the late 1990s or America's stock market bubble in the late 1920s'. The ACT joined the worldwide exuberance for property and, between March 2001 and 2006, Canberra's median house price rose by 87 per cent, from $\$ 203,500$ to $\$ 380,000$ (All Homes, 2006). The spike in house prices saw the Government reap windfall gains from stamp duty receipts. It got $\$ 51 \mathrm{~m}$ more than expected in 2001/02, \$23m extra in 2002/03 and $\$ 70 \mathrm{~m}$ more in 2003/04 (ACT Budget, 2001/02-2005/06). By dint of its unique history the ACT Government is the monopoly supplier of land in the territory and land sales are an important part of its revenue. At the height of the property boom, in 2003/04, the Government received $\$ 92$ million more in revenue from land sales than it had anticipated (ACT Budget, 2003/04 and 2004/05).

At the same time the Goods and Services Tax was beginning to deliver on its promise as a growth tax. In 2003/04 the ACT was one of the first jurisdictions to receive more from the GST than the Guaranteed Minimum Amount (GMA) ${ }^{1}$, and the revenue from it has exceeded expectations in every year since (ACT Budget, 2003/04). The territory's share of the GST in 2005/06 was $\$ 713 \mathrm{~m}$, $\$ 45 \mathrm{~m}$ over the GMA. In $2006 / 07$ it is estimated at $\$ 760 \mathrm{~m}$, or $\$ 63 \mathrm{~m}$ more than anticipated (Australian Treasury, 2006).

On the jobs front the main engine in the territory, Commonwealth Government employment, was humming. The Coalition's election in 1996 had been accompanied by a vigorous bout of cost cutting which drove the territory economy into recession and saw public service numbers drop to a low of 47,400 by February 1999. Thereafter employment began to climb and, by February 2006, the number of Canberra-based, Commonwealth public servants had risen 32 per

1 The GMA ensured no state or territory would be worse off after the introduction of the GST, with the Commonwealth underwriting an agreed figure for each state and territory. 
cent to 63,000 (ABS, 2006b). This was a level of Commonwealth employment not seen in the territory since August 1989.

The rapid growth in the public sector saw the demand for new office space jump. In 2003, 52,500 square metres of new or refurbished stock was added to the city, following 81,400 square metres in 2002. Most of the space, 67 per cent, was occupied by government tenants (Jones Lang La Salle, 2004). Another 135,000 square metres is under construction.

These weren't just good times, these were unprecedented times and the Stanhope Government was clearly benefiting from all the activity. Measuring Government revenue expectations against outcomes between 2001/02 and 2005/06 shows the territory received an average of $\$ 210 \mathrm{~m}$, or about 10 per cent, more money each year than it anticipated. Total extra revenue over that time was just over $\$ 1$ billion (ACT Budget, 2001/02-2006/07).

To this the ACT Government responds that it also had a series of unexpected costs during its tenure. The largest was the January 2003 bushfire, followed by inquires which demanded significant extra funding for disability services and child protection. In the Chief Minister's 2006/07 budget speech he details these costs from the time they were incurred until 'the end of this budget estimates period' or 2009/10 (Stanhope, 2006a:12). This is misleading as some of those dollars are yet to be spent, while the gains mentioned above have already occurred. Bearing that in mind, the Government estimates the additional costs of the bushfire at $\$ 154 \mathrm{~m}$, disability services at $\$ 76 \mathrm{~m}$ and child protection at $\$ 134 \mathrm{~m}$ (Stanhope, 2006a:12). That would reduce its windfall gain to $\$ 636 \mathrm{~m}$ : still a handy sum in a territory which expects total revenue in 2006-07 to be $\$ 2.6$ b (ACT Budget, 2006/07).

\section{The Fall}

This happy set of circumstances should have seen the ACT in a strong financial position and if you followed the Government's headline budget figure each year that was the story it told. But the Government's way of calculating the number was deceiving everyone, including its ministers. According to the tables at the front of ACT Budget Papers, the territory was in surplus by $\$ 61 \mathrm{~m}$ in $2002 / 03$, by $\$ 93 \mathrm{~m}$ in $2003 / 4$ and by $\$ 52 \mathrm{~m}$ in 2004/05 (ACT Budget, 2002/03-2005/06). But the ABS (2006) says the surplus was $\$ 12 \mathrm{~m}$ in 2002/03, followed by deficits of $\$ 197$ and \$291 million. The difference is due to two sets of accrual accounting standards. The territory was using Australian Accounting Standard No 31 (AAS31) and the ABS was tracking the numbers through Government Finance Statistics, the uniform national standard.

AAS31 was issued in 1996 and the territory adopted it when it moved its books from cash to accrual accounting (ABS, 2000; Barton, 2005). However, because it treated money from land sales, rises in the value of its assets such as infrastructure, and hikes in its share portfolio as income, no different to taxes or grants from the Commonwealth, it served to disguise the slide in the territory's financial position (Access Economics, 2005:63). So, while the territory was inflating its bottom line with money it could not spend, real money was 
haemorrhaging from Government coffers. Between 2001/02 and 2005/06 expenses grew by 28 per cent (ACT Budget, 2002/03-2006/07).

The money was largely going on a rapidly expanding public service and significant wage rises. Between its election in October 2001 and May 2005 the Stanhope Government increased the public sector workforce by 2300, from 17,300 to 19,600 (ABS, 2006b). At the same time it was pushing up public sector wages, arguing that the previous Liberal Government had unfairly suppressed them. In the 21 months to March 2006, teacher salaries were increased between 15.5 per cent and 18.7 per cent and other wages followed a similar trajectory (ACT Department of Education and Training, 2004). Spending on public sector wages in the ACT over this period has been described by economist Dr Mike Nahan (2006:7) as 'out of control'.

Although it is the seat of federal government, few serious analysts concern themselves with what many deride as Canberra's 'toy-town' parliament and very little real scrutiny is applied to how it conducts its affairs. However, a small but significant group was watching, with growing alarm. Access Economics (2005:3) noted:

unlike other States and Territories the ACT's annual general government operating expenses are currently being funded, to a significant extent, by asset sales and investment windfalls. ... Such a financing strategy is not sustainable in the medium to long run.

Writing in the Australian Financial Review, former NSW Auditor General, Tony Harris (2006:46) said the Stanhope Government was forecasting a deficit for 2005/06 of \$356m or 'more than \$1000 a person':

For larger governments, a deficit of \$356 million might be worrying, but it would not be calamitous. ... But for the ACT, its forecast deficit is sizeable. If NSW had a similar per-capita budget outcome, it would have a deficit of $\$ 7$ billion. And, in spite of soothing forecasts, the ACT's problem seems persistent.

More importantly, the credit ratings agency Standard \& Poor's (2005:6) had its eyes fixed firmly on the GFS figures and saw 'disturbingly high general government operating deficits'. In March 2006, Danielle Westwater, an associate in the agency's Sovereign and International Public Finance Ratings Group, issued a public warning to the Government. Speaking to The Canberra Times (Uhlmann, 2006:3), she said the strength of the territory's balance sheet gave it some headroom for dealing with its operating deficit, 'although this strength only buys so much time'. She went on to say:

Standard and Poor's has been warning for the last few years that the operating deficit is a concern and that persistent operating deficits are not consistent in the long term with a AAA credit rating. 


\section{Who Knew?}

There is some evidence the now-retired Treasurer, Ted Quinlan, was warning his fellow ministers that their spending was unsustainable. In a letter to the then Minister for Urban Services, Bill Wood, he expressed concern at a capital works program Wood's department was proposing. Quinlan (2002) said he was committed to ensuring capital works costs did not continue to increase. 'This is important as we do not have cash capacity in future years' budgets to continue to fund large capital works programs'. In interviews since his retirement, Quinlan (2006) has indicated he also raised the issue of runaway recurrent spending in Cabinet but his protests were ignored.

There is no evidence Stanhope realised there was a problem until a Cabinet meeting in 2005. There, confronted with figures on the surge in public service numbers, he reportedly expressed anger and disbelief. When questioned about this on ABC Radio, in April 2006, he admitted he had been 'somewhat alarmed' by the increase (Stanhope, 2006b:1039). It was a remarkable admission and, when questioned about it in the Assembly, he said (p. 1040):

I was, and remain, surprised by some of the level of growth within the ACT public service over the last four years - actually over the last three years because it has not grown at all in the last year.

This jolted Stanhope into action and, in late 2005, he unilaterally decided to establish the Functional Review of the ACT Public Sector and Services, while Quinlan was overseas.

\section{The Correction}

The review was led by the former head of the Department of Foreign Affairs and Trade Mike Costello and economist Greg Smith. It was tasked with benchmarking government expenditure 'against other jurisdictions and to identify options to improve efficiency through more effective government structures' (ACT Treasury, 2006b). The review was also asked to make recommendations for reducing expenditure, or increasing non-taxation revenues.

The report of the Functional Review has been kept secret but Stanhope gave a reasonable summary of the ground it covered in an article in The Canberra Times. There he laid out his view that the key problem with territory finances was historical over-servicing. Stanhope (2006c) noted that the territory's younger, healthier, better educated population should make delivering services cheaper than elsewhere. In practice the reverse was true.

The cost per hospital separation is 20 per cent higher than the national average. ... On pre-school education we spend almost double the national benchmark. On tourism we spend 72 per cent more per capita than the national benchmark. Our spending on community health is 34 per cent higher, our spending on general public services almost double 
and our expenditure on superannuation almost 140 per cent higher than in other jurisdictions. Since 2000/01 the number of teachers in our government schools has risen by 6 per cent. In the same period the number of students has fallen by 7 per cent. Expenditure per student is about 20 per cent above the national average.

The content of the review is perhaps best judged by how it shaped the 2006/07 Budget. After years of lax fiscal management the Government signalled a dramatic turn: raising taxes; slashing services; cutting public sector jobs; dropping its employer superannuation contributions from 15.4 per cent to 9 per cent; and, reorganising the bureaucracy, creating a central shared services centre (ACT Budget, 2006/07). Dominating the headlines since is the proposed closure of 17 schools and 22 preschools between 2006 and 2008 (ACT Department of Education and Training, 2006a).

\section{The Shadow of the Past}

Despite the obvious shortcomings of his Government, Stanhope does have a point when he raises structural problems that have dogged the territory since 1989. They are partly the result of planning decisions made in the 1960s and 1970s when the territory was run by the Commonwealth. Although the ACT was established in 1911 and Parliament moved in after the 1926 election, its development was arrested by wars, depression and apathy. But once the Menzies Government committed to moving central departments to Canberra the city expanded rapidly. It grew from a population of 28,300 in 1954 to 144,000 in 1971, taking it from the $19^{\text {th }}$ ranked Australian city by size to the $8^{\text {th }}$ largest. Between 1961 and 1972 the population grew at an average of 10 per cent a year (John Patterson Urban Systems, 1972:1).

The National Capital Development Commission (NCDC) coordinated the planning for growth, devising Canberra's distinctive Y-plan and dispersing the relatively small population into a series of town centres, separated by vast tracts of open space and connected by 2422 kilometres of road (Committee of Inquiry into the Assets and Public Debt of the Australian Capital Territory, 1990). Each centre was surrounded by suburbs and each suburb had a little hub of a neighbourhood primary school and some shops.

This was a command economy at work. Then the NCDC (1964) could dictate where Commonwealth agencies set up and its vision was that each towncentre would have a government employment centre, 'to provide working places for a significant proportion of the residents of that town and also encourage balancing flows of commuter traffic between town centres'. NCDC documents show that its ambitions for Canberra grew with the city. In 1964 it speaks of a city of 250,000 (NCDC, 1964). Six years later it was planning for a population in excess of 600,000 by the year 2000 (NCDC, 1970).

If the population growth of the 60s and early 70s had continued in the 80 s and 90s, Canberra would have easily bettered the commission's expectations. But the 
growth was entirely dependent on government policy, and governments change. The arrival of the Fraser Government saw Canberra's annual population influx drop from about 12,000 a year in 1976 to 3000 in 1981. In 1981, the population went backwards for the first time in 27 years, with a net loss of 300 people (NCDC, 1983:2). Those coming to Canberra during its rapid expansion were a relatively homogeneous group of young adults and children with 'immediate needs for preschools, schools, health services and retail facilities' (NCDC, 1983:9). So the NCDC kept building on its established pattern, flinging expensive infrastructure about with abandon, long after it should have become obvious that this was unsustainable.

\section{The Move to Self-Government}

In the lead-up to self-government, the Commonwealth Grants Commission (CGC) began unravelling the territory's finances from those of the Federal Government through a series of inquiries. In 1988, the commission's third report on financing the ACT found the territory was getting $\$ 76 \mathrm{~m}$ more in grants from the Commonwealth than the commission deemed necessary to provide an Australian standard of service. It also found the territory's revenue raising effort was about 83 per cent of the national average (CGC, 1988).

The CGC found territory services were above the Australian average just about everywhere it looked but, for simplicity, schools can stand as an example for all. The report said the territory spent double the average on pre-schools, 16 per cent over the average on primary schools and 20 per cent more on secondary schools (CGC, 1988). It is of course open to any jurisdiction to spend more on services than the grants commission determines is necessary to deliver the Australian standard but that jurisdiction, not the Commonwealth, has to fund the difference.

The grants commission's findings can be interpreted in different ways and, as the issue persists to this day, it is still a matter of debate. It could be that the ACT is paying for services that are among the best in Australia, or it could be a sign of waste. It is probably a bit of both. The current government's decision to close 39 schools suggests it believes at least some of the money is being wasted and, as we shall see, there is plenty of evidence to support that view. In pushing the territory into self-government, some in the Hawke Government were clearly motivated by a belief that the cost of Canberra was over the odds and it was time for ACT residents to pay their way. Former finance minister Peter Walsh, told the author in 1999 that the Commonwealth excised the territory because it had become too expensive to keep.

The Hawke Government's plan for clawing back money from the capital was to shift responsibility for putting a lid on its finances to the new local government. It disentangled the territory's running costs and administration from the Commonwealth and set a timetable for winding back grants to state-type levels over a 10-year transition period. Shortly after self-government arrived in 1989, two inquiries were tasked with examining the state of the territory's finances and 
suggesting a way forward. The first was the Committee of Inquiry into the Assets and Public Debt of the Australian Capital Territory and the second was the Priorities Review Board. The first was led by former grants commission chair Justice Rae Else-Mitchell and the second by a director of Westpac Bank, Robert White. Both raised serious concerns about the level of over-servicing across the board.

Else-Mitchell's committee was critical of the way the transition to selfgovernment had been handled and said the Commonwealth had run down assets in the years before the handover. It identified a $\$ 25 \mathrm{~m}$ maintenance backlog and criticised the NCDC's planning (Committee of Inquiry into the Assets and Public Debt of the Australian Capital Territory, 1990:12). Of the territory's vast road system the committee said (p. 35):

these assets were produced by the NCDC with minimum concern for long-term maintenance considerations. The committee was of the view that the national capital standards imposed by the NCDC may not have been those a territorial or municipal government would have chosen for a city of comparable size.

On schools, Else-Mitchell's committee found the system 'presently has an excess capacity of 20 per cent, representing 13,000 spaces available in the Department's primary and secondary schools'. It was pleased to hear that the Education Department would 'seek to continue its policy of consolidation with between 15 and 25 school sites to be closed over a period of four years' (p. 20).

White's committee noted the 'significant and continuing demographic changes in the ACT over the past decade', leading to declining enrolments, and recommended the closure of 21 schools over six years (Priorities Review Board, 1990:131). It never happened. The Alliance Government proposed closing 20 schools, succeeded in closing three and promptly lost office. The incoming Follett Labor government re-opened two schools. Since then, ACT governments have had little appetite for reform of the school system.

As a result, the decline in the number of school aged students, combined with a significant shift to the private sector, has seen the problem first identified in the early 1980s get much worse. When the committees reported in 1990 there were 40,552 students attending 97 government schools (Harrison 1993:164). There are now 35,463 attending 95 (ACT Department of Education and Training, 2006:1)

The ACT Government is now fighting an education battle on two fronts, trying to close schools and limit teachers' wage increases. This is just one of a number of fights it must win if it is to meet the ambitious savings targets in this year's budget and bring its deficit under control.

\section{Conclusion}

The Stanhope Government has argued its financial plight is largely due to structural problems left untended in the 17 years of self-government. In this 
construction it is both victim and hero: the present budgetary problems are not of its making; and, it is the first government in the short history of the territory to have the courage to make painful changes. There is some merit in this argument but it doesn't bear a lot of scrutiny. If the government had truly been alive to structural problems it would have begun to make changes in its first term, not halfway through its second. And, if these problems were entirely the cause of its current woes then why did the dramatic plunge into deficit appear so rapidly, some 14 years into self-government. Earlier territory governments have been in deficit, albeit by smaller amounts, and worked their way into surplus. They worked with the same structural problems and in much tougher economic climates.

The evidence available shows the Government is largely the author of its own woes. It suggests the Government believed its own rhetoric when it claimed, year after year, to be in surplus. It is speculation but a reasonable person could conclude that some members of the Stanhope cabinet did not understand the flaws in the accounting system over which they were presiding. Certainly the Chief Minister's astounding admission that he was surprised by a 13 per cent increase in the size of the public service under his watch does nothing to encourage the view that he has a firm grasp of the consequences of his decisions.

There is some good news. The first is that the territory has abandoned AAS31 and is now using a GFS-like measure. The ACT version includes expected-long term capital gains on superannuation investments as revenue, which makes the headline deficit appear better than the nationally accepted standard. However, it is a vast improvement on what went before and means that the public and the Chief Minister are less likely to face nasty surprises in future. The second piece of good news is that, no matter what standard you apply, there has been an improvement in the budget bottom line. ACT Treasury's June Quarter Financial Report (ACT Treasury, 2006a) showed an improvement in the outcome for 2005/06 of over $\$ 71 \mathrm{~m}$, no matter how you measure it. Unfortunately, the Government used the report to give the flattering AAS31 numbers one more public outing, even though it abandoned the standard in this year's budget. On August 15 a front page story in The Canberra Times claimed that the Government had recorded a surplus of 2005/06 of $\$ 176 \mathrm{~m}$, the largest in the territory's history (Mannheim, 2006). Under the Government's new standard the figure was a deficit of $\$ 91$. Using pure GFS it was a deficit of $\$ 123 \mathrm{~m}$. And politicians wonder why people don't trust them.

\section{References}

Access Economics (2005), State and Territory Budget Monitor, Canberra.

ACT Budget 2006/07 (and earlier years), available from ACT Department of Treasury Canberra, http://www.treasury.act.gov.au/budget/index.shtml.

ACT Department of Education and Training (2004), 'Teaching Staff Certified Agreement 2004-2006', Canberra. 
ACT Department of Education and Training (2006a), 'Towards 2020: Renewing our Schools', Canberra.

ACT Department of Education and Training (2006b) 'Government School Bulletin: Census', Canberra.

ACT Treasury (2006a), ‘June Quarter Consolidated Financial Report’, Canberra.

ACT Treasury (2006b), ‘Fact Sheet NoF1: Functional Review’, Canberra.

Allhomes (2006), 'Median House Price 1991-2006', http://allhomes.com.au/c/ah?a=propertyreport, accessed 27 August, 2006.

Australian Treasury (2006), 'Statement of Estimated Payments to the States and Territories', Canberra.

Australian Bureau of Statistics (2000), 'Accruals Based Government Finance Statistics', Cat. No. 5517.0, Canberra.

Australian Bureau of Statistics (2006a), 'Government Finance Statistics Australia, 2004/05', Cat. No. 5512.0, Canberra.

Australian Bureau of Statistics (2006b), 'Wage and Salary Earners, Public Sector, Australia', Cat. No. 6248.0.55.001, Canberra.

Barton, A. (2005), 'Issues in Accrual Accounting and Budgeting by Government', Agenda 12(3):211-226.

Commonwealth Grants Commission (1988), 'Third Report 1988 on Financing the Australian Capital Territory: Part Two - Analysis of Findings’, Australian Government Publishing Service, Canberra.

Committee of Inquiry into the Assets and Public Debt of the Australian Capital Territory, (1990), ACT Government, Canberra.

Harris, T. (2005), 'ACT Spends Political Capital, The Australian Financial Review 17 January.

Harrison, M. (1993), ‘Education’, pp. 159-197 in D. Hughes and R. Albon (eds), Capital Ideas: Suggestions for Economic Reform in the ACT, Federalism Research Centre, Australian National University.

John Patterson Urban Systems (1972), 'Canberra - Considerations of City Size', Melbourne.

Jones Lang LaSalle (2004), 'Canberra Property, Planning for 2007 and Beyond', Sydney.

Mannheim, M. (2006), ‘ACT Records Largest Surplus Ever of \$176m”, The Canberra Times 15 August.

Nahan, M. (2006), 'Opportunity Squandered: How the States Have Wasted their Reform Bonus’, Institute of Public Affairs, Melbourne.

National Capital Development Commission (1964), The Future Canberra, Commonwealth Government Printer, Canberra. 
National Capital Development Commission (1970), Tomorrow’s Canberra! Planning for Growth and Change, Australian National University Press, Canberra.

National Capital Development Commission (1983), Canberra's Population Projection 1983-1993, NCDC, Canberra.

Quinlan, T. (2002), 'Letter to Bill Wood', November 21.

Quinlan, T. (2006), 'Interview with Ross Solly on ABC Radio 666', Canberra, 6 June.

Standard \& Poor's (2005), Australian Capital Territory Report, Standard and Poor's, Melbourne.

Stanhope, J. (2006a), ‘Budget Speech 2006/07’, ACT Government, Canberra.

Stanhope, J. (2006b), Hansard May 2006:1039-1040, ACT Legislative Assembly, Canberra.

Stanhope, J. (2006c), 'Narrow Revenue Base to Blame for Territory’s Financial Trouble', The Canberra Times, 12 April.

The Economist (2005), 'The Worldwide Rise in House Prices is the Biggest Bubble in History’, 16 June.

Uhlmann, C. (2006), 'Credit Rating Threat for ACT', The Canberra Times, 2 April.

The author wishes to acknowledge the help of three anonymous referees and urges economists in Canberra to take an active interest in ACT Government financing. At present there is almost no expert, independent, scrutiny of this jurisdiction. 



\section{Monetary Targeting Policy}

\section{Simon Guttmann, The Rise and Fall of Monetary Targeting in Australia, Australian Scholarly Publishing, Melbourne, 2006 \\ Reviewed by Graeme Wells}

A ndy Warhol once said that 'in the future, everyone will be world-famous for 15 minutes'. He was observing that, with luck and good media management, lack of talent is no bar to temporary celebrity status.

Perhaps this also applies to economic policy prescriptions - in this interesting book Simon Guttmann makes a convincing argument that this was true of the monetary targeting episode in Australia from January 1976 to January 1985. The policy was advanced during the election campaign and adopted by the incoming Liberal-Country Party coalition at a time when, in 1975, consumer prices were almost 17 per cent higher than a year earlier and the unemployment rate was more than 8 per cent. Clearly, a strategy to control inflation was required to win the election and in 1975 Milton Friedman's widely-publicised visit to Australia prepared the ground for monetary targeting.

'Monetary targeting' refers to the policy of manipulating macroeconomic policy instruments so as to achieve a pre-announced growth rate of some monetary aggregate. In the early 1970s the basis for monetary targeting comprised several elements.

It was argued that, although there may be a short-run tradeoff between inflation and economic activity (with higher activity being obtained at a cost of higher inflation), there is no tradeoff in the long run. As people come to expect higher inflation, they adjust their behaviour in ways which offset its effects - to give one example, wage negotiations take account of expected inflation and change labour supply, shifting employment back to its original level. So higher inflation is not associated with higher output and employment in the long run. The corollary of this argument is that, if policy-makers could convince people to expect a fall in inflation, a cut in inflation could be obtained with only a small short term cost to activity.

The other elements were, first, that the authorities can exercise control over some monetary aggregate and, second, that inflation is closely related to it. In Australia the chosen aggregate was M3, which is the sum of currency on issue and the public's deposits at banks. So, if M3 growth has a predictable and causal relation to an ultimate policy target such as price inflation, monetary targeting 
provides a framework for formulating policy which is effective and easily communicated to the public.

Guttman argues convincingly that these requirements were not met in the mid 1970s, and that this was well-understood by the Reserve Bank. Empirical studies did not suggest a tight relation between M3 growth and inflation in Australia. Nor was it likely that close control of M3 would be possible. In the early 1960s, for example, work by Robert Mundell, Marcus Fleming and Harry Johnson had established that in the absence of restrictions on international capital flows, it would be impossible to achieve monetary targets if the exchange rate were fixed, or adjusted infrequently, as was the case in Australia over most of the targeting period.

Market-determined interest rates were also required if monetary growth was to be insulated from the effects of budget imbalances. This requirement was not met either, because until the early 1980s the Treasury set the interest rates on government securities, with the Reserve Bank being the residual purchaser or seller of the imbalance between Treasury supply and private-sector demand for securities. In turn, changes in Reserve Bank holdings of government securities change the monetary base and hence the money supply.

Although the Reserve Bank and the Treasury were aware of the difficulties of successfully implementing an inflation targeting regime, they both supported it. Guttmann argues that an important reason for Treasury support was that under the system of regulated interest rates, with the Reserve being the residual purchaser of government securities, monetary targeting provided a discipline on the size of the fiscal balance. The Reserve Bank, on the other hand, hoped that adoption of monetary targeting would lead the Treasurer to adopt policies necessary for its effective implementation. Deregulation of interest rates, which would have involved an increase in the power of the Reserve Bank at the expense of the Treasury, was an important requirement.

In these circumstances it is hardly surprising that (apart from two early successes) targets were not met, or that the difficulties inherent in the targeting regime were not clearly understood by financial markets and the wider public.

Lack of transparency had its costs. Deregulation of financial markets in the early 1980s removed controls on bank interest rates, floated the exchange rate, and removed Treasury controls on government-security interest rates. This meant that banks started to win back business from nonbank financial institutions (NBFIs). Since M3 included the deposits of banks but not deposits of NBFIs, M3 growth became an increasingly unreliable guide to monetary conditions and in January 1985 targeting was abandoned by then Treasurer Keating. The newly elected Labor government had yet to establish its economic credentials and financial markets took fright, depreciating the Australian dollar and raising the international risk premium on Australian interest rates.

Although the Reserve Bank could have foreseen that financial market deregulation (which for the first time gave the Reserve the tools with which to 
implement an effective monetary policy) would pose problems for M3 targeting, no alternative strategy was readily available. It would be almost a decade before the present policy of inflation targeting was put in place. Over the 1980s, average CPI inflation in Australia was substantially higher than in Japan, the United States, the Euro area and the United Kingdom. The promise of monetary targeting - that changing inflationary expectations could achieve disinflation at low cost — was not realised.

Australian macroeconomic policy is again governed by pre-announced targets - the Reserve Bank's inflation target and the government's target for the fiscal balance. The CPI targeting regime has a number of features which suggest that the Reserve Bank has learned valuable lessons from earlier experience. Control of CPI inflation is a final objective of policy rather than an intermediate target, and the Bank has operational independence from the Treasury in the use of the cash rate to achieve its target. The target applies to a longer horizon than the twelvemonth time frame for monetary targets. It is defined in terms of achieving a target range of 2-3 per cent CPI inflation 'over the cycle'. While reference to the 'cycle' leaves a degree of wriggle room - it may refer to either a 'classical' or 'growth' cycle, for instance - it sensibly allows for temporary deviations outside the target range. Finally, the Reserve now goes to some length to explain its policy actions and, largely as a result of its efforts, the complexities of policy implementation are well understood by Australian financial markets and policy commentators.

On the other hand the Government's present fiscal strategy, which is to maintain the budget in balance over the course of the economic cycle, retains echoes of the monetary targeting era. Targeting was seen as an indirect mechanism to restrict the size of budget deficits. Now the fiscal target is explicit, although the precise measure of the fiscal deficit is open to manipulation by the Treasurer.

But like the monetary target, the budget balance is an intermediate target and its relationship to the ultimate objectives of policy is unclear. One suspects that the focus on the budget balance is, like monetary targeting and the equally shortlived emphasis on the current account deficit which followed it, a simple-minded device to justify other policies. It may be a useful way to constrain the expenditure claims of sectional interests, for example. Or it may be an indirect way to target the current account deficit by boosting national saving. But it is much less useful if pursuit of budget surpluses results in inaction with regard to efficiency enhancing tax reforms, or expenditures which pass cost-benefit criteria.

Guttmann has written a useful and interesting book. For observers outside the political-policy process it provides a timely reminder of the difficulties of implementing good policy. The book is enlivened by the personal recollections of a range of individuals - politicians, policy advisers, academics, officers of the Reserve Bank and the Treasury, and prominent newspaper columnists. An apposite quotation is from then Reserve Bank governor Sir Harold Knight who, 
when giving an account of his appearance before the Campbell Committee, could not recall 'just how far I permitted myself the liberties of plain speech' (p. 144).

An important message of this book is that economic policy would have been better served if those involved had implemented monetary targeting with a clear idea of what it could achieve, and used plain language to explain the policy to the public.

Graeme Wells is an Associate Professor in the School of Economics and Finance at the University of Tasmania. 


\title{
Globalisation and New Zealand
}

\author{
Ralph Pettman (ed.), New Zealand in a Globalising World, Victoria \\ University Press, Wellington, New Zealand, 2005
}

\section{Reviewed by Martin Richardson}

$\mathrm{T}$ The book is a collection of conference papers edited - and I use the term loosely: collated might be more accurate — by Ralph Pettman, a Professor of International Relations. Professor Pettman was the first person I ever heard deploy — at a conference in the late 90's — the Walt Whitman 'Song of Myself' gambit:

Do I contradict myself?

Very well then I contradict myself,

(I am large, I contain multitudes).

This book plays this academic 'Get out of Jail Free' card too, but goes one better: it is small and it contains contradictions. Granted: different perspectives are generally to be welcomed in a conference volume. But one expects an editor to contribute an essay that highlights these differences, and maybe attempts to synthesise or reconcile them. No such luck here: the collator's sole contribution is a 2-page paean to a retiring colleague. Nor is there much evidence of actual editing. Certainly there's none in the selection of the papers. Neither is there an Index. And the proofreading apparently deemed acceptable such sentences as, 'The Australian environment minister, Senator Robert Hill, was “dead" without the US's agreement'. (p. 59)

This book has fourteen chapters of which, in my judgement, three are worthwhile. The first section on New Zealand in a Globalising World has a good paper by Robert Patman on sovereignty. (A declaration of interest: I was at the same institution as Prof. Patman for eight years, and contributed a paper to a unique volume on Globalisation and New Zealand (Patman and Rudd, 2005) he co-edited recently.) This piece is clear and sensible and the author is seeking not to uncover any global truths but to present balanced evidence on a particular hypothesis. Unfortunately, the hypothesis is pretty uncontroversial - that the impacts of globalisation on sovereignty are neither zero nor large enough to emasculate the state. Still, the chapter is reasoned and convincing.

John Henderson's excellent paper in the second section (on New Zealand's Role in the Pacific) is another highlight that provides a very clear comparison of Australia and New Zealand as Pacific actors, and provides some concrete and sensible proposals for a Pacific Island peacekeeping force. Keith Suter's chapter 
in the same section also has its moments, as Rossini said of Wagner. Suter is in the 'globalisation changes everything' camp. He is totally mistaken in that regard; his understanding of economics is non-existent; he blames all of the ills of the Pacific on colonialism (as if the region would be all prosperity and light in some other counterfactual); and his conclusions - of the naïve 'why can't we all just get along?' ilk - ignore the appalling track record of international aid. But, despite disagreeing with almost all of it, I thoroughly enjoyed the chapter, as it is well-structured, provocative and interesting.

But that's it for highlights. I am broadly a fan of globalisation, believing it generally has a positive influence in the world. But it is not always and everywhere a Good Thing and, in Chapter 2 of this volume the reader feels the clammy touch of the dark side of globalisation: French deconstructionism in a book on New Zealand by an Argentinian author. This piece has the lot - verbing (as in 'to free-trade'); nouning (as in a 'global'); even the use of quotation marks as a wink to the reader to indicate his nuanced understanding of meaning. This is captured nicely in the following sentence (p. 32):

A 'global' that excludes the 'local' or any 'local' is not a real global but another 'local', it is a restricted global, a particular and regional global.

This should really be sung aloud by a light opera company to get the full effect and, indeed, the author is the very model of a postmodern social scientist (but, alas and of course, with no facts, cheerful or otherwise). There is a website at Monash University which generates postmodern essays at random - a pomobot, it might be called — and clearly the author knows the URL.

To be fair, this is the worst chapter in the book and perhaps it's churlish to pick on its obscurantism. So let's pick on another. Here's a co-defendant (p. 159):

The ontological and epistemological links between indigenous and migrant cultures and a distinctive primordial conception of legitimacy, is juxtaposed with the competing, and seemingly dominant, constructivist postcolonial antipodean nation-state derived from the enduring legacy of British colonial history.

In contrast to Chapter 2, however, that possibly has some meaning — it's just that the author has laboured hard to conceal it.

The first section of the book plunges through these fables of the deconstruction to a 'Globalisation and me' chapter by a veteran New Zealand economist. It's the sort of self-referential musing you'd expect from a grand old man of the profession but, in the author's defence, two out of three ain't bad and, at least, he's brief. No, the volume's lowlights are really concentrated in the final section, Trans-Tasman Relations. The contributions here range from the ponderous, through idle thoughts over a cup of tea, to the casual aphorism. The 
infimum in this set is the contribution of - incredibly — a former New Zealand ambassador to the UN who lays out a worldview so one-eyed it astonished even this fellow Kiwi. Australia shows 'disdain' for multilateralism as evidenced by its attitude to the Kyoto Protocol. New Zealand 'does not seek international prestige as Australia does' (p. 144) New Zealand has the 'self-belief to pursue' the 'goal of reconciliation' (p. 146), unlike Australia. While Australia recognises 'the rule of invincibility and compliance with the paramount power' (p. 150), New Zealand espouses 'the rule of law equitably applied by all states' (although we're told on the previous page that New Zealand, 'seemingly accepted' the Australian view that UN approval was not needed to intervene in the Solomons in 2003. I am large, I contain multitudes.) With a breathtaking lack of irony or self-awareness, the author also tells us that Australian attitudes toward New Zealand are 'disparaging' (p. 145) 'trite and facile' stereotypes (p. 146), while New Zealand's foreign policy is, 'non-threatening, with an aptitude for impartiality and problem solving' (p. 144). I am perfectly happy for an author to present a steaming vat of polemic and opinion if he is explicit about it, but I do resent the deception when it's served up with a garnish of academic styling to disguise it as analysis.

All up, I'd urge anyone inclined to buy this slim volume to save your money, borrow the book from a library, and photocopy the good chapters with a clear conscience - they are sufficiently few in number that you'll not violate any fair use statutes in doing this. Three worthwhile chapters out of fourteen suggests that publication in the conference volume was a carrot offered to participants. That's admirably inclusive, I suppose, but the lack of editorial discrimination actually does a disservice to the authors of the weak chapters who are falsely encouraged; to the authors of the good work here who are tainted by association; and, of course, to the reader.

There is one question a reviewer of an academic book must always ask 'Have I learned anything from this volume?' - and one that must be asked of any book - 'Is it worth buying?' Well, yes and no. And I don't mean that in a Whitmanesque way, either.

\section{Reference}

Patman, R. and C. Rudd (2005), Sovereignty under Siege? Globalization and New Zealand, Aldershot, Ashgate, UK.

Martin Richardson is Professor, School of Economics, The Australian National University. 


\title{
Microeconomics 1 as it Should Be
}

\author{
Tim Harford, The Undercover Economist, Little, Brown, UK, 2006
}

\section{Reviewed by Declan Trott}

$\mathrm{W}$ Tho pays for your coffee? With this simple yet wrong (think about it!) question, Financial Times columnist Tim Harford begins his discussion of David Ricardo's theory of economic rent. Using as his main example, not the original corn lands or mines, but coffee stands in prime locations such as London's Waterloo station, he shows how the rents of the best locations are governed by the worst, the marginal sites at which the price can just cover the cost of production. 'Undercover', then, does not imply danger, illegality or breathtaking revelations, just a man going about his everyday business with a few extra intellectual tools to make sense of the world around him. This sets the pattern for the rest of the book: economic theory used to make sense of quirky yet commonplace situations.

Fortunately, the chapter titles make more sense after the first. 'What Supermarkets Don't Want You to Know' illustrates the different forms of price discrimination, covering not only supermarkets but railways, pharmaceuticals and airlines. 'Perfect Markets and the "World of Truth"', unsurprisingly, sketches how a world of perfectly competitive markets could bring about efficient outcomes, 'Crosstown Traffic' and 'The Inside Story' how externalities and asymmetric information spoil this story. 'Rational Insanity' is an apt a description as any of herding in financial markets, while 'The Men Who Knew the Value of Nothing' is not a description of mad economists selling rain forests and small children but an excursion into game theory via the trials and tribulations of radiospectrum auctions. 'Why Poor Countries Are Poor', 'Beer, Chips and Globalisation' and 'How China Grew Rich' are more standard applications of comparative advantage and Olsen's stationary bandit theory.

It is easy to praise this book. In a market where introductory textbooks are growing ever larger, more colourful, and more expensive, the author has taken some of the most important ideas in economics, made them as simple as they can be (but no simpler), and related them to examples that are real, relevant and interesting. All in around 250 pages with 5 simple black and white graphs. The opinions and policy prescriptions are unsurprising for a Financial Times columnist - free trade is good, environmental and fair trade activists are often misguided, tradeable permits and taxes are the best way to solve pollution and congestion. (Unfortunately, Bastiat's famous quip about throwing rocks in your own harbour is attributed to Joan Robinson, which surely has them both spinning in their graves!) Yet while Harford exhibits flashes of unjustified dogmatism - 'trade 
barriers will always do more harm than good' and holding up South Korea as a shining example of free trade - his views are generally more nuanced, separating goods trade and direct investment from financial openness in his discussion on globalization, and praising China's pursuit of gradual reforms and 'growing out of the plan', rather than fire-sale privatization Russian style. For the reviewer, though, it is the points of disagreement that are the most interesting, and it is to those I now turn, minor though they are in comparison.

It is, I think, a great strength of the book that it starts with monopolistic competition - firms with some price setting power, but still constrained by rivals, rather than the pedagogically more common (but empirically less so) extremes of pure natural monopoly or perfect competition. Yet the full implications of this pervasive market structure are not fully appreciated. At the end of the second chapter, good price discrimination which expands the size of the market (selling retroviral drugs to the Third World at close to marginal cost) is contrasted with bad price discrimination which merely redistributes goods from high to low value consumers (granting student concessions on public transport). Leaving aside the empirical question of whether full fare commuters have self evidently more price elastic demand than First World AIDS patients or concession travellers, there is the unexamined assumption that a single fare would allow the service to be profitable enough to continue. The unavoidable dilemma whenever there is some fixed cost and marginal costs do not increase with output is that the efficient, marginal cost price loses money, while any increase in price is inefficient. Successful price discrimination may therefore determine whether the product exists at all, not just whether the quantity provided is marginally more or less efficient. This dilemma is never squarely faced, unlike the problems posed by externalities and imperfect information. In 'Perfect Markets' it is simply stated that marginal cost price is efficient. This could not be applied to most sectors of the economy without a vast system of subsidies and restrictions on entry.

Aside from fixed costs, one of the very few areas of basic microeconomics neglected by Harford is the classification of goods based on rivalry and excludability. This may be asking too much of a work that, after all, does not claim to be a textbook. Yet claiming that 'the basic rules for making money in the high-tech business are not so different from the rules for train operators or coffee bars' does not seem quite satisfactory. Although the concepts marginal cost and revenue are the same, and Hartford allows that the cost structures are different due to high $\mathrm{R} \& \mathrm{D}$ and low manufacturing costs, the combination of low rivalry in the intellectual property and low excludability thanks to easy piracy makes the software, pharmaceutical and music industries more different than he admits, and less susceptible to even a second-best market solution. Similarly, lumping police and schools together when considering government versus private provision is rather crude.

One piece of terminology is also unfortunate. As if the word 'monopoly' is to be avoided at any cost, 'scarcity power' is used instead, which indiscriminately 
covers cases of natural scarcity such as good crop land, differences in the efficiency of organizations (which are rather confusingly also called 'natural'), contrived monopolies through government regulation or criminal violence, or simply skills that are in short supply.

Yet with these reservations, The Undercover Economist is still superb. If I had to recommend a single book to introduce a non-economist to the field, or for a lecturer about to teach first year micro, I could not think of a better.

Declan Trott is a PhD Candicate in the School of Economics, The Australian National University. 


\section{NON-AGENDA}

With the view of causing an increase to take place in the mass of national wealth, or with a view to increase of the means either of subsistence or enjoyment, without some special reason, the general rule is, that nothing ought to be done or attempted by government. The motto, or watchword of government, on these occasions, ought to be - Be quiet... Whatever measures, therefore, cannot be justified as exceptions to that rule, may be considered as non-agenda on the part of government.

\section{Private Sector Lessons for Public Sector Reform in Indonesia}

\section{Ross H. McLeod}

Although the Indonesian economy grew very rapidly — averaging over 7 per cent per annum - during the three decades of the Soeharto era, it suffered a severe setback with the onset of the Asian crisis in 1997-98, and has been unable to achieve similar growth rates on a sustained basis subsequently. The year-on-year growth rate for the March quarter, 2006 was only 4.6 per cent, and this rate has fallen consistently since the end of 2004 (Manning and Roesad, 2006:146). Although most output is generated by the private sector, growth also depends heavily on the provision of complementary inputs by the public sector, most obviously physical infrastructure and an effective legal system. The fact that successive Indonesian governments have performed poorly on both these fronts provides a partial explanation for the relatively low economic growth rates of recent years.

In addition, the private sector is greatly hampered by masses of red tape created by the bureaucracy, as is readily apparent from annual studies undertaken by the World Bank group and published under the general title Doing Business, which are described as 'a series of annual reports investigating the scope and manner of regulations that enhance business activity and those that constrain it' (World Bank, 2004a:viii). According to the latest (2006) report, Indonesia is ranked as low as 115 in a total of 155 countries in the Doing Business database in relation to the 'Ease of Doing Business'.

Ross McLeod is Associate Professor, Indonesia Project, Division of Economics, Research School of Pacific and Asian Studies, The Australian National University. 
In these reports each country's overall Ease of Doing Business ranking is based on its subsidiary rankings on some 10 sub-indices (for details on the Doing Business methodology, see: http://www.doingbusiness.org). Table 1 (based on the 2006 report) presents a selection of the most important of these.

The inadequacies of Indonesia's legal system are reflected in the first two sub-indices, which focus on operations of the judiciary: Enforcement of Contracts, and Closing a Business. In relation to the former, Indonesia scores extremely poorly $-145^{\text {th }}$ among the total 155 countries. Small wonder, then, that private sector entities in Indonesia largely avoid using the courts for contract enforcement - relying instead on other means of protecting their interests, such as the use of private debt collectors, or simply being very careful in their choice of people to do business with. In relation to the latter sub-index, which is basically concerned with the efficacy of bankruptcy procedures, Indonesia ranks $116^{\text {th }}$.

\section{Table 1: Ease of Doing Business in Indonesia: Selected Sub-index Components}

\begin{tabular}{l|l}
\hline & Rank (among 155 countries) \\
\hline Ease of doing business & $\mathbf{1 1 5}$ \\
Matters relying heavily on the courts & 145 \\
Enforcing contracts & 116 \\
Closing a business & \\
Matters involving the bureaucracy & 144 \\
Starting a business & 120 \\
Hiring and firing workers & 118 \\
Paying taxes & 107 \\
Registering property & 107 \\
Obtaining a license & \\
\hline
\end{tabular}

Source: World Bank (2006)

The stultifying impact of the public sector bureaucracy on private sector activity is indicated by the second group of sub-indices. These relate mainly to aspects of private sector business operations that are heavily dependent on the issue of permits, licences, statements, approvals and so on by the bureaucracy (and, to a small extent, by the police). Indonesia ranks as low as $144^{\text {th }}$ in relation to the ease of Starting a Business. Once a business can be established, the weight of bureaucratic regulation of the labour market (Hiring and Firing Workers) pushes Indonesia to $120^{\text {th }}$ place on this aspect, similar to its ranking on the ease of complying with taxation requirements (Paying Taxes). The nation fares little better when it comes to bureaucratic obstacles to Registering Property or Obtaining a Licence, for both of which its ranking is 107. 
The reports do not look at infrastructure deficiencies, but another World Bank (2004b:1, 4) document has this to say:

Indonesia's infrastructure quality ranks among the lowest in the region and is affecting growth, poverty reduction, foreign investment, and the environment... A key impediment is the lack of an overall government strategy for infrastructure and predictable policies in ... critical infrastructure sectors.

\section{The Missing Sector in Sectoral Studies}

Clearly, then, Indonesia's economic progress is greatly hampered by the inadequacies of its public sector. Although the latter is one of the most important sectors of the economy, development economists have done very little to analyse its efficiency and how this might be improved. The focus instead has been on other sectors, such as agriculture, forestry, fishing, manufacturing, mining, telecommunications, transportation, financial services, and so on. Studies of these sectors are often concerned with their efficiency, factors that affect this, and policies that might increase it. Relative neglect of the public sector may reflect the near impossibility of measuring its output, without which there can be no direct measure of efficiency. But the Doing Business reports clearly show that the efficiency of the public sector in Indonesia leaves a great deal to be desired; nobody with any personal experience of its functioning could argue otherwise.

We could draw up an endless list of examples, such as the failure of the taxation and customs authorities to collect anything like the full value of revenues legally due (World Bank, 2003a); the failure of relevant departments and enforcement agencies to prevent illegal logging (Obidzinski, 2005), mining (Erman, 2005) and fishing (Fegan, 2005); the lack of attention to protecting the environment (World Bank, 2003b); the abysmal state of infrastructure (World Bank, 2004b); the poor quality of the state education and health systems (World Bank, 2003a); the fact that individuals and firms see the police and the judiciary more as predators than protectors (World Bank, 2003c); and the seeming inability of the bureaucracy to draft sensible legislation (McLeod, 2006). As the World Bank (2003c:ii) noted:

Corruption levels by any objective standard appear very high, and cause the vast majority of Indonesians themselves to see corruption as an evil that must be eradicated

but while this is receiving considerable attention from the present government, the problem is much wider than corruption. The simple fact is that the public sector is grossly inefficient, which necessarily holds back the performance of the economy as a whole. 


\section{Growth Accounting}

Another strong focus of the development literature in recent years has been 'growth accounting', in which the attempt is made to explain differences in countries' growth rates by looking at factors such as spending on education and health, and the types of policies followed by their governments - particularly in relation to foreign trade, investment and industrialisation. These kinds of studies generate recommendations as to what constitute 'good' policies, but the question as to whether the bureaucracies in question are even interested in 'good' policies - let alone capable of discerning what they are and implementing them - is largely ignored.

This is not particularly helpful. It is logically inconsistent for economists to continue to feed policy recommendations to the Indonesian government when we are confronted on a daily basis with clear evidence that its civil service is highly dysfunctional - which implies that those recommendations are very unlikely to be implemented properly, if at all. For this reason a great deal of the work of economists in the development field in Indonesia seems rather futile. The most pressing priority is to focus on the bureaucracy itself, and to try to find ways to improve its effectiveness. The greater the extent to which this can be achieved, the less the need for outside advice as to what constitutes sound economic policy: a competent civil service can, by definition, design and implement sensible policies and programmes (subject, of course, to political constraints).

Although development economists - at least, those who work on Indonesia - have not devoted much effort to analysing public sector performance, part of the public administration literature does concern itself with efforts to improve the effectiveness of this sector. The so-called 'New Public Management' literature has at its core the main hypothesis that a shift to market orientation in the public sector - applying competition as it is known in the world of profit-oriented business activity - will lead to greater cost-efficiency for governments. The New Public Management concept originated in countries such as the UK and New Zealand (Borins, 2000), and has generated a wave of public sector reforms in many countries since the 1980s, but it seems to have had virtually no impact in Indonesia. As will shortly become apparent, the aim here - in keeping with the New Public Management approach - is to use ideas from private business activity to generate suggestions for civil service reform in Indonesia.

\section{Organisation Performance and Competition}

\section{Progress through emulation}

In all forms of human endeavour some progress is possible through formal training, but probably the main path to advancement is by emulating what others are doing if their performance is clearly superior. The principle is basic commonsense. If my friend can hit the golf ball twice as far as I can, then I should 
try to swing the club more like he does. If one fisherman comes home with a much bigger catch than another, the latter will do well to use similar techniques. If one farmer gets a significantly higher yield from his rice crop, his neighbour would be well advised to copy his methods.

Thus, an obvious point to make is that the Indonesian government could quite easily learn some good ideas about how to improve the performance of its bureaucracy simply by looking at how the civil service operates in any number of other countries; those that rank highly in the Doing Business reports, such as New Zealand, Singapore, the US, Canada, Norway and Australia, would be obvious choices. Indeed, sending bureaucrats and politicians on comparative study tours overseas is a well practised art in Indonesia. Unfortunately, however, most of these study tours have little or no impact, because they are based on the incorrect assumption that civil servants have a strong incentive to increase the effectiveness of their own organisations, lacking only the knowledge of how to do so. On the contrary, most of those who undertake these tours regard them as little more than opportunities to see the world and to supplement their meagre salaries with travel allowances; they are under no illusion that they will be initiating any grand reforms when they return.

\section{Learning from business}

An alternative approach involves making comparisons, not with other countries' bureaucracies, but with other kinds of organisation in quite different fields of activity. In particular, governments can learn a lot about how to improve the performance of their bureaucracies by focusing on the private sector. This idea is anathema to many, perhaps most, Indonesian civil servants, who are accustomed to believing that the economy could hardly function were it not for their wise guidance. My own view on this, supported by the broad findings of the Doing Business reports, is quite the opposite: the civil service (and its associated state enterprise sector) is, by and large, a blight on economic performance. Indonesia's economic progress to date has been in spite of, rather than because of, the bureaucracy.

Why should we imagine that the public sector has anything to learn from the private sector? Nearly all firms have competitors, and if they do not perform as well as these competitors their profits will be low, if not negative. With the passage of time, the more efficient firms will gain larger shares of the market, while others will wither and ultimately die. As poorly performing firms disappear, the resources they would otherwise employ - labour, capital, land and other natural resources - become available for reallocation to more efficient firms and industries, where their now higher productivity will increase the overall size of national income (Ter Wengel and Rodriguez, 2006). In short, the whole process is strongly geared to steady improvement in performance over time.

The keys to high performance here are financial incentives and competition. The financial incentive is the owners' prospect of making large profits by performing well relative to competitors, combined with the risk of losing 
previously accumulated savings (wealth) by performing poorly. The firms that can supply products with superior combinations of price and characteristics desired by their customers will be those that prevail.

The eventual disappearance (through closure or takeover) of relatively poorly managed firms has no counterpart in the public sector. Broadly speaking, national level bureaucracies have no competitors. Thus there is no natural or automatic process that pushes public sector bureaucracies continually to improve their performance. Having made the point that such a process is of crucial importance in the field of business enterprise, it is an obvious next step to infer that its absence helps explain why bureaucracies like those in Indonesia suffer from chronic poor performance, and to suggest that a solution may be found in emulating the practices of successful private sector firms in the area of human resource management.

\section{Building Competitive Teams}

It is axiomatic that the performance of any organisation depends on the performance of the individuals that comprise it. To prosper in a competitive environment, firms need to use people with a range of skills: engineering, scientific, financial, marketing, procurement, administration, personnel management and so on. The decisions made, and the work done, by their employees determine whether the firm succeeds or fails. The job of marketers is to discover what products consumers want; that of engineers to design these and the corresponding production processes; of procurement officers to purchase material and services inputs from reliable, low-cost suppliers; and so on.

Most fundamental of all, the function of human resource management is to ensure that the company recruits sufficient numbers of people with all these kinds of skills, and provides them with strong incentives to perform well. If this function is poorly conceived or managed, the firm is unlikely to survive. In principle, all this is no different from the process of managing the players in a professional football team, where the objective is to put the most effective players in each of the different positions, subject to the price that must be paid to acquire their services.

\section{Competing for places on the team}

Though it is not often discussed or thought of in these terms, the key to the human resource management function is to operate a competition - or, rather, a large number of ongoing competitions for every position within the firm, from the highest to the lowest level. Of course, the number and quality of those who apply for each position will depend upon the remuneration on offer, and the trick here is to seek the optimal trade-off between productivity and cost. Highly productive people will cost more, and it will be worthwhile to recruit somewhat less productive people if the saving in wages or salaries is sufficient to offset their lower productivity. Conversely, although low productivity personnel will be 
relatively cheap to hire, it will be worthwhile to recruit somewhat more productive people if the productivity gain exceeds the extra cost of wages or salaries.

Obviously, firms have no choice other than to offer wages and salaries similar to those offered by other firms; they will have difficulty recruiting workers other than those with low productivity if the wage offered is also low. And they will have difficulty keeping workers on the payroll if their productivity is high enough to get them a job at another, higher paying employer. Of course, payments may be made in kind as well as monetary wages, and firms often find it worthwhile to provide a package of benefits such as transportation, meals, health benefits, housing assistance and so on as part of the overall compensation package, if it is perceived that these benefits will be more highly valued by employees than the cost of providing them. Ultimately, however, individuals are competing for jobs, employers are competing for workers, and the overall price paid is basically determined by the market.

An important additional consideration that makes jobs more or less attractive to employees is the prospect of promotion. If employees are confident they can expect promotion that properly reflects the increasing productivity that accompanies the accumulation of experience and skills (whether by formal or onthe-job training, or learning by doing), they will have a strong incentive to work hard and find ways to increase their productivity. From the firm's point of view, it will be relatively easy to recruit highly motivated and capable personnel if prospects for rapid career advancement appear bright.

In this sense the career trajectory of employees is rather like the evolution of firms: indeed, the employee is exactly analogous to a firm selling services to a customer, the customer in question here being the employer. Employees best able to convince their employer that they have a superior 'product' to sell will be those that obtain the most rapid promotions. Employers that don't want to be disappointed will take care to appraise the performance of current employees, to compare this with that of their peers, and to use these appraisals as important inputs to the promotions process.

\section{Human Resource Management in Indonesia's Civil Service}

As mentioned above, thinking along these lines provides an explanation for why the functioning of Indonesia's civil service leaves so much to be desired, and thus puts us in a position to propose a set of principles to guide civil service reform. The preceding discussion of the process of competition among business enterprises suggests that the poor performance of the Indonesian bureaucracy can be explained by the fact that it has no competitors. It has comparators in the bureaucracies of other countries, of course, but these are not competitors for the privilege of managing the Indonesian economy and polity, and so they are largely ignored. Absence of the need to compete and thus to improve performance continuously has led to significant departures from the fundamental principles of sound human resource management that we see in operation in the profit-oriented world of business. 
First, all parts of the Indonesian bureaucracy have a very rigid organisational structure in which the number of positions at each level in the hierarchy is fixed mechanically by formula, rather than by reference to the volume of work required to be carried out at that level (hence the ubiquitous gross overstaffing at lower levels).

Second, there is very little by way of job classification, except for a few highly specialised professions such as medicine, which means that there is little matching of professional skills and qualifications to the tasks to be carried out (hence the frequent occurrence of a lack of requisite skills at higher levels). It is not widely known that Indonesia had a system of classification or categorisation of positions throughout the civil service until very early in the Soeharto era, when this system was dropped in favour of a military kind of organisational structure in which new recruits were not differentiated other than by the level of education attained (ADB, 2004:58). Yet there is a considerable variety of types of work to be done in the civil service as a whole and within individual ministries, many of which require specific professional skills. It makes no sense to recruit history graduates if what is required is engineers, so it is hardly surprising that many people find themselves undertaking work for which they are not properly trained. This means not only that they will not be able to do their jobs well, but also that their valuable skills will not be fully utilised.

Third, the incentives for good performance on the part of civil servants are very weak, since the current approach ensures that they face no competition from outside: almost the only competition is among (not from) new secondary and tertiary graduates for entry-level positions. Incumbents also face no competition from below, as individuals can only be promoted when positions become vacant because of promotion, relocation, retirement, death or incapacitation of the previous incumbent. Moreover, competition for vacant positions is further limited by obstacles to moving around different parts of the civil service, and by the imposition of seniority (minimum years of service) prerequisites, the effect of which is to reduce the number of individuals eligible to be considered.

Finally, to the extent there is competition for positions, the rules of the game are weak and the playing field is far from level, such that it is common for people to seek promotion not by demonstrating superior performance than their peers but by ingratiating themselves with their superiors and by bribing officials who have the authority to make the appointments in question.

\section{The Process of Organisational Reform}

There is of course no scope for creating competition for the central government bureaucracy: it has a permanent monopoly. (By contrast, with the devolution of many functions of government to regional governments ['decentralisation'] in 2001 the opportunity now exists for provincial, district and municipal governments to compete amongst themselves to attract labour and capital from other parts of the country.) Rather, the key to reform is to recognise that, as with all other organisations, the performance of the civil service depends on the 
performance of the individuals that comprise it - and that this, in turn, depends on the incentives they face and on their capabilities relative to the jobs they are required to do.

It follows that the most promising path to reform involves trying to emulate the human resource management practices of organisations that compete strongly among themselves - in particular, profit-oriented businesses. The key to success is human resource management: putting superior teams of individuals together, and providing them with the appropriate incentives to do well. The way to do this is wholeheartedly to embrace the notion of creating ongoing, fair and vigorous competition for all positions within the civil service.

Once the desirability of encouraging strong competition for civil service positions is accepted, the first concrete step in civil service human resource management reform is to document all the different kinds of jobs that need to be undertaken (as distinct from those that currently exist) in each part of the bureaucracy. For each position, the skill and experience requirements should be described. Next is to determine an appropriate salary for each position, based on research into the private sector labour market directed to discovering the going rates for all relevant combinations of skills and experience.

The end result will be a complete listing of all genuinely needed positions in each department, together with their corresponding salary levels or ranges. This listing would replace the current exceedingly complex and non-transparent system, in which total remuneration has numerous components and depends heavily on characteristics of the individual - including educational qualifications, years of service and number of dependants - as well as the characteristics of the position - most importantly, its level in the hierarchy.

Just as the New Public Management approach emphasises the importance of government procurement of goods and services at lowest cost (for specified quality) through competitive processes, efficiency and attention to the interests of the general public require that the government should not pay more than necessary to attract people with the necessary skills and experience. They also require that the salaries offered are in line with what is being offered by the private sector. In other words, salaries should be differentiated by the type of qualification and by the level of experience, as distinct from the number of years of service and the level in the hierarchy. A person who has served for a long time but at relatively low levels of responsibility should not be paid as much as someone who has served successfully, perhaps for a shorter time, but at a higher level of responsibility.

This requires rethinking what constitutes 'fairness' in salary-setting in the civil service. In the view of the author, the only salary structure that can be called 'fair' is one that matches what is available in the market. Civil service salaries should not have any welfare payment component (that is, they should not include a subsidy by being set above market rates), nor should they try to save money by being set deliberately below market levels. This is false economy: artificially low salaries will attract relatively low productivity people, or they will attract those whose deliberate intention is to engage in corrupt activity in order to achieve at 
least what they could earn outside the civil service. In both cases the saving in salaries is offset by some combination of low productivity and 'leakages'.

In short, it is fair if everybody in the society has the right to offer himself or herself for employment in the civil service. By contrast, it is not fair if people already in the service are protected from competition from outsiders who may be prepared to work harder, who may have taken the trouble to acquire higher qualifications, or who for other reasons may be more capable. By increasing salaries to market levels it will be possible to dispense with the convenient but usually false notion that incumbent civil servants are making big sacrifices and therefore deserve to be protected in their positions. Nobody will be expected to make any sacrifices, so nobody will have any grounds for claiming special treatment.

The next step in civil service human resource management reform is to compare what is needed with what is already available. On the basis of first hand observation of the Indonesian bureaucracy over nearly three decades, the author believes the following will be found:

- a surplus of employees in many positions as a result of a promotions process that treats promotion as a right rather than something to be earned through superior performance, and organisational structures that take no account of the number of people actually needed to do each kind of work within the organisation;

- a relatively large number of individuals who have been promoted into particular positions simply because they have the requisite formal qualifications and a sufficient level of seniority, and yet who are incapable of filling these positions adequately;

- many other individuals who are deserving of promotion to higher positions but who have been held back by lack of seniority or lack of formal qualifications; and

- a lack of needed skills and experience in key areas, especially at the higher levels. ${ }^{1}$

On the basis of this 'stocktake' of human resource requirements and availability, the next phase of the reform process entails:

\footnotetext{
${ }^{1}$ The author recently had the opportunity to observe directly some of these realities when working briefly with an Indonesian government agency whose workload has increased dramatically with the advent of decentralisation. Lack of recruitment to junior levels over many years has left the agency with a severe lack of staff with requisite professional skills at higher levels. But the constraints on recruitment from outside and on rapid promotion from within mean that these positions cannot be filled, implying that the agency itself faces enormous difficulty in expanding its role. At the same time, a visit to the agency's training centre revealed that it had literally scores of administrative support staff, yet only four full-time trainers.
} 
- $\quad$ promoting individuals who appear to be capable of performing well at levels higher than their current positions;

- recruiting individuals from outside to fill human resource gaps if the appropriate people are not available from within; and

- encouraging the departure of individuals who are surplus to requirements, including those previously promoted to levels beyond their capabilities.

Obviously it is no easy matter to rid the organisation of employees who are not needed, or to change a system in which people are accustomed to think of regular promotions as their entitlement, even though both changes are clearly in the interests of the general public. But this is not something that has never been done before. The process of turning around any underperforming organisation typically requires dealing with precisely these kinds of issues. Radical change of this nature usually requires the appointment of a person at the apex of the organisation in question with demonstrated strong management and leadership skills, who is given the responsibility for restructuring, along with the autonomy to push ahead relatively free from outside interference. Again, lessons can be learned from the experience of competitive business enterprises.

Consider the relatively recent restructuring of the then highly unprofitable national airline, Garuda, and the merger of four large and insolvent state-owned banks to form Bank Mandiri. In both cases, the government brought in Robby Djohan, a highly respected CEO from the (private) banking sector, to restructure these very large enterprises (Djohan, no date). Djohan was given near total freedom to do what he felt was necessary to turn these firms around. In both cases he did so successfully by installing his own top management team, selecting the best people within the organisations to fill the remaining positions, and providing generous voluntary retirement packages to other employees no longer needed. He was able eventually to obtain the support of those being let go, not to mention those being rewarded by way of promotion into positions of greater responsibility. These examples show that radical surgery on the workforces of state enterprises - having a great deal in common with the civil service — is politically feasible in the Indonesian context.

Having said that, it should also be noted that both organisations, no longer under Djohan's leadership, have subsequently fallen on hard times, which is a reflection of the desirability of privatisation (the logical, extreme, extension of the New Public Management approach applied to state-owned enterprises). This suggests that further steps need to be taken to ensure that initial gains from reconstituting the workforce in each part of the public sector can be sustained.

\section{Sustaining High Performance}

Beyond the initial restructuring, sustained reform requires implementation of a system that is as competitive as possible: one that is open to competition from below and from outside. Broadly speaking, each position should be contestable by anyone. Current civil servants should be able to apply for different positions 
regardless of their level of seniority; and recruitment from outside should not be restricted only to filling base level positions with new graduates from high schools and tertiary education institutions, but should encompass the recruitment at higher levels of older workers whose experience has been gained in the private sector, in academia, or wherever.

Of fundamental importance here is a set of rules of the game that make the competition fair, combined with mechanisms for enforcing those rules. This is basically about transparency and accountability. Positions should be openly advertised; applications should be properly recorded; selections should be determined by small committees (including at lease one 'outsider') rather than by individuals; the reasons for choosing particular applicants and not others should be documented; and unsuccessful applicants should have the right of appeal to a higher authority. The function of the last in such cases is to review all of the documentation and try to ensure that the only consideration in choosing the successful applicant has been the attempt to get the best available person for the job in question, given the salary on offer.

To the extent that applicants come from outside the civil service it will be necessary for them to demonstrate the adequacy of their qualifications and skills, and to furnish references from past employers. Again, all of this will need to be documented. On the other hand, for individuals seeking promotions or lateral movements within the civil service, records will need to be kept of those individuals' working experience and performance appraisals. Performance appraisals will be required to be undertaken at regular intervals by the individual's superior officer, and the individual should have the right to see these appraisals and to comment on them and contest them, again by appeal to a higher authority. The objective in all this is to ensure that individuals' work is honestly and adequately appraised.

These kinds of systems have been developed in government organisations in other countries and in large business enterprises, from which much can be learned. Presumably there is no such thing as the perfect system, but there can be little doubt that some systems are much closer to perfection than others. The aim should be to emulate systems that appear to function well in other organisations, with due regard for the local context.

\section{Summary}

The key points of the argument presented here in relation to civil service reform in Indonesia are as follows.

First, economic performance overall depends, to a significant extent, on the economic policies designed by governments and bureaucracies in the countries in question. Whether sound policies are chosen, and then designed and implemented properly depends, to a significant extent, on the quality of the civil service. As with all other organisations, the performance of the civil service depends on the performance of the individuals that comprise it, which, in turn, depends on the incentives they face and on their capabilities relative to the jobs they are required 
to do. Performance of individuals can be improved — and indeed maximised — if the guiding principle of personnel management is to encourage strong competition for positions within the civil service, thus emulating the practices of successful business enterprises and of governments in other countries that have embraced New Public Management approaches. A commitment to competition needs to be supported by a clear set of rules governing that competition, and by provisions for enforcement of those rules: the competition must be fair.

Second, the present system of personnel management within Indonesia's civil service departs significantly from these basic principles, which largely explains why its performance is clearly sub-standard. All parts of the bureaucracy have a very rigid organisational structure, in which the number of positions at each level in the hierarchy is fixed by a mechanistic formula, not by reference to the volume of work required to be carried out at that level. There is very little by way of job classification in the civil service except for a few highly specialised professions, which means that there is little matching of professional skills and qualifications to the tasks to be carried out. Civil service incumbents face no competition from outside. The only competition is among new secondary and tertiary graduates for entry-level positions. Civil service officials face no competition from below, since individuals can only be promoted when positions become vacant following the promotion, relocation, retirement, death or incapacitation of the previous incumbent. Competition for vacant positions is limited not only by the ban on recruitment from outside the civil service but also by obstacles to moving around different parts of it, and by the imposition of seniority requirements to limit the number of individuals eligible to be considered. To the extent there is competition for positions, the rules of the game are weak and poorly enforced, such that it is common for people to seek promotions by ingratiating themselves with their superior officers and by bribing officials that have the authority to make the appointments in question.

On the basis of these arguments and observations it is the author's view that the key to reform of Indonesia's civil service, and therefore to maximising the contribution of the public sector to Indonesia's development, is to extend New Public Management approaches regarding the procurement of goods and services to the sphere of human resource management, by encouraging vigorous and fair competition for positions within the civil service.

\section{References}

Asian Development Bank (2004), Country Governance Assessment Report, Republic of Indonesia, Manila, http:// www.adb.org/Documents/Reports/CGA/ino.asp.

Borins, S. (2002), 'New Public Management, North American Style', Ch. 11 in K. McLaughlin, S. Osborne, and E. Ferlie (eds), The New Public Management: Current Trends and Future Prospects, Routledge, London and New York.

Djohan, R. (no date), The Art of Turnaround: Kiat Restrukturisasi, Aksara Karuna, Jakarta. 
Erman, E. (2005). 'Illegal Coalmining in West Sumatra: Access and Actors in the PostSoeharto Era', pp. 206-15 in B. Resosudarmo (ed.), The Politics and Economics of Indonesia's Natural Resources, Institute of Southeast Asian Studies, Singapore.

Fegan, B. (2005), 'Offshore Fishing', Box 10.1 in I. Dutton, 'If Only Fish Could Vote: The Enduring Challenges of Coastal and Marine Resources Management in PostReformasi Indonesia', pp. 162-78 in B. Resosudarmo (ed.), The Politics and Economics of Indonesia's Natural Resources, Institute of Southeast Asian Studies, Singapore.

Manning, C. and K. Roesad (2006), 'Survey of Recent Developments', Bulletin of Indonesian Economic Studies August:143-70.

McLeod, R. (2006), 'Indonesia’s New Deposit Guarantee Law’, Bulletin of Indonesian Economic Studies April:59-78.

Obidzinski, K. (2005), 'Illegal Logging in Indonesia: Myth and Reality’, pp. 193-205 in B. Resosudarmo (ed.), The Politics and Economics of Indonesia's Natural Resources, Institute of Southeast Asian Studies, Singapore.

Ter Wengel, J. and E. Rodriguez (forthcoming, 2006), 'Productivity and Firm Dynamics: Creative Destruction in an Indonesian Panel Data on Manufacturing, 1994-2000', Bulletin of Indonesian Economic Studies December.

World Bank (2003a), CGI Brief: Beyond Macroeconomic Stability, Report No. 27374-IND, World Bank, Washington DC.

World Bank (2003b), Indonesia Environment Monitor 2003, World Bank, Washington DC.

World Bank (2003c), Combating Corruption in Indonesia: Enhancing Accountability for Development, World Bank, Washington DC.

World Bank (2004a), Doing Business in 2004: Understanding Regulation, World Bank and International Finance Corporation, Washington DC.

World Bank (2004b), Averting an Infrastructure Crisis: A Framework for Policy and Action, World Bank, Washington DC.

World Bank (2006), Doing Business in 2006: Creating Jobs, World Bank and International Finance Corporation, Washington DC.

The author gratefully acknowledges helpful comments from two referees, which have led to significant improvements in the paper. 